DEPARTMENT OF THE INTERIOR

UNITED STATES GEOLOGICAL SURVEY

GEORGE OTIS SMITH, DIRECTOR

WATER-SUPPly PAPER 371

\title{
EQUIPMENT FOR CURRENT-METER GAGING STATIONS
}

BY

G. J. LYON

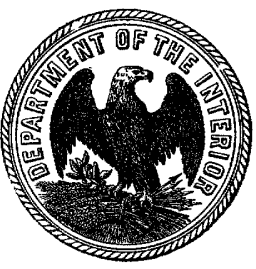

WASHINGTON

GOVERNMENT PRINTING OFFICE

1915 


\section{CONTENTS.}

Page.

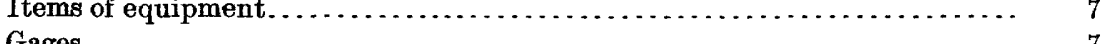

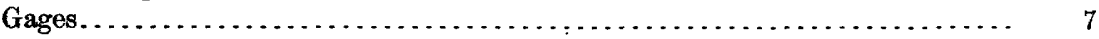

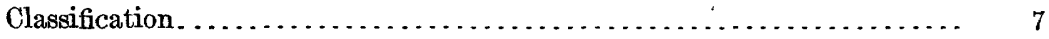

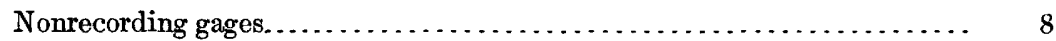

Vertical-staff gage . . . . . . . . . .

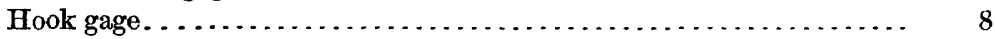

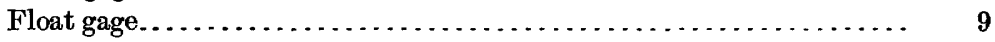

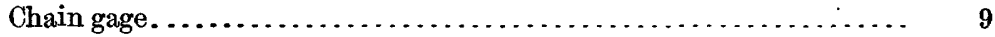

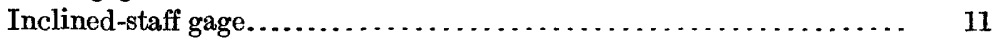

Essential features......................................... 11

Gage on concrete piers............................... 11

Gage attached to timber posts....................... 12

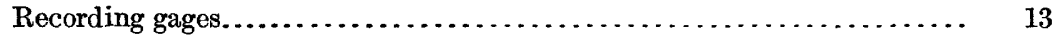

Essential features of installation......................... 13

Well and intake...................................... 14

Materials and dimensions........................... 14

Methods of construction............................. 15

Timber-lined wells. . . . . . . . . . . . . . .

Anchorage for intake pipe......................... 19

Plain and reinforced concrete wells................. 20

Concrete combination well and shelter............... 22

Miscellaneous designs. ............................ $\quad 23$

Protection from freezing............................ 24

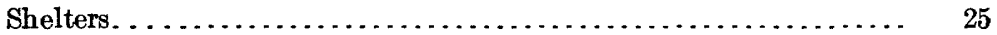

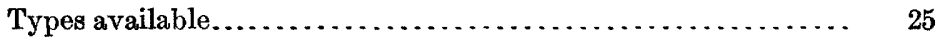

Sectional wooden shelters.......................... . 25

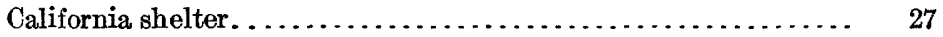

Box shelter....................................... 29

Portable shelter................................... 30

Plain-concrete shelter................................ 31

Reinforced-concrete shelter........................... 35

Miscellaneous designs. ............................... 37

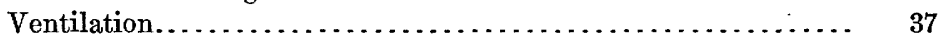

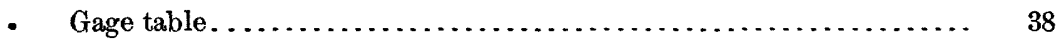

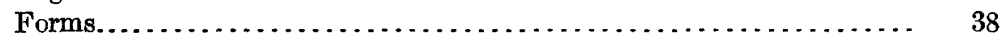

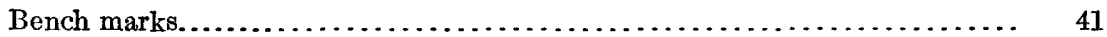

Structures used in making discharge measurements. . . . . . . . . . . . . 41

Essential parts............................................. 41

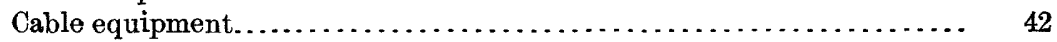

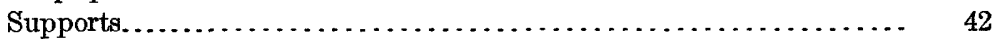

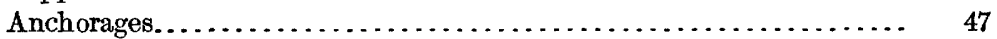

Common types................................... 47

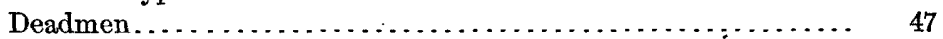

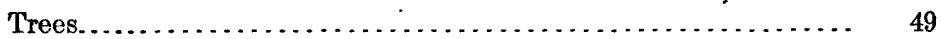

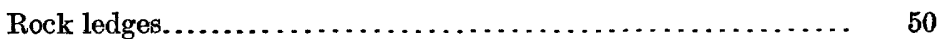


Structures used in making discharge measurements-Continued.

Cable equipment-Continued.

Cable and accessories.

Turnbuckles..................................... $\quad 52$

Clips........................................... 53

Backstay........................................... 53

List of materials................................. 53

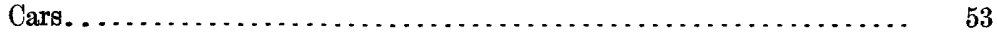

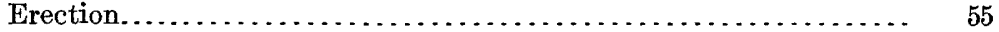

Bridges..................................................... 57

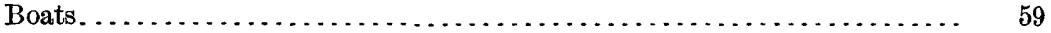

Stay lines.................................................. 60

Lines for indicating measuring points......................... 61

Artificial control. . . . . . . . . . . . . . . . . 61

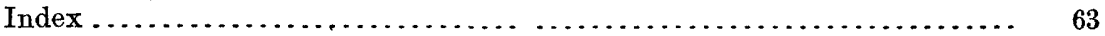

\section{TABLES.}

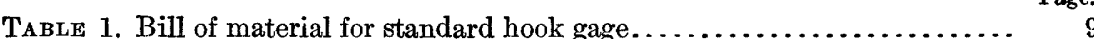

2. Bill of material for chain-gage box.................... 10

3. Bill of material for inclined gage on concrete pi rss............ 12

4. Bill of material for inclined gage on timber posts............. 13

5. Bill of material for standard timber well box ............... 16

6. Bill of material for plain concrete well supporting a standard timber shelter. ....................................... 20

7. Bill of material for reinforced-concrete well with timber or metal

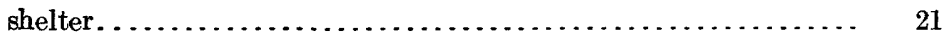

8. Bill of material for combination concrete well and shelter.......... 22

9. Bill of material for standard wooden shelter ................. 26

10. Bill of material for California-type well and shelter............ 28

11. Bill of material for box-type shelter......................... 29

12. Bill of material for portable shelter......................... 31

13. Bill of material for concrete well and shelter for automatic recording

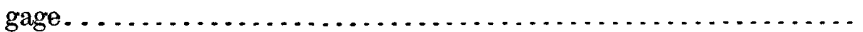

14. Bill of material for reinforced-concrete well and shelter for automatic

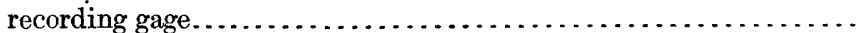

15. Bill of material for standard gage table. . . . . . . . . . . . . . .

16. Bill of material for concrete forms for reinforced-concrete well and

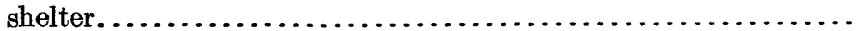

17. Dimensions of top and side plates and bolts..................

18. Spacing of holes in side plates. . . . . . . . . . . . . . . . . . .

19. Bill of material for 8 -foot frames. . . . . . . . . . . . . . . . . .

20. Bill of material for 12 -foot frames. . . . . . . . . . . . . . . . .

21. Bill of material for 16 -foot frames. . . . . . . . . . . . . . . . .

22. Bill of material for 20 -foot frames. . . . . . . . . . . . . . . . .

23. Length and depth of installation of deadmen.................

24. Distance from foot of A frame to deadmen....................

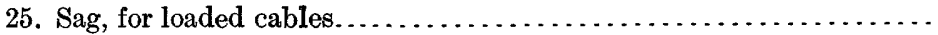

26. Erection sag (in feet' and tension in erecting cables ............. 
TABLE 27. Smallest allowable cable, with corresponding sag for various spans..

28. Bill of material for cable intallation. ....................

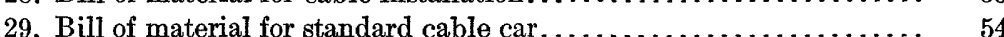

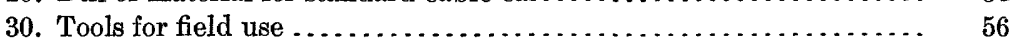

31. Bill of material for wooden footbridge. . . . . . . . . . . . . . 57

32. Bill of material for ferry cable trolley . . . . . . . . . . . . . . 60

33. Data for selection of stay lines....................... 60

\section{IILUUSTRATIONS.}

Plate I. $A$, Vertical-staff and hook gages; $B$, Vertical and inclined staff gages.

II. Plan of chain-gage box and weight. . . . . . . . . . . . . . .

III. Plans for inclined staff or slope gage. . . . . . . . . . . . . . . .

IV. Typical automatic recording gages: $A$, Stevens; $B$, Gurley; $C$, Friez.

V. $A$, Typical gaging station with automatic gage; $B$, Well with no intake and with shelter of box type, Agua Fria River at Glen-

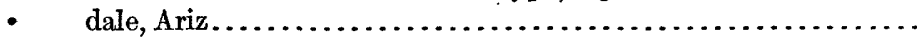

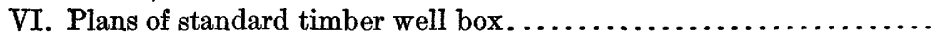

VII. $A$, Well in a rock bank, Green River at Bridgeport, Utah; $B$, California type of shelter, San Dieguito River at Bernardo, Cal......

VIII. Plans of plain-concrete house and well; sections and details of in-

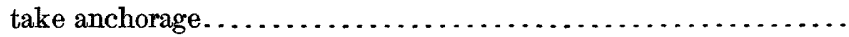

IX. Plans of reinforced-concrete well and shelter.................

X. $A$, Reinforced-concrete well and shelter, American River at Fairoaks, Cal.; $B$, Concrete well and shelter combined, Muddy River

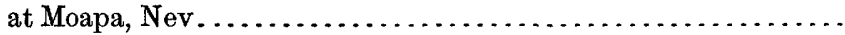

XI. Plans of combination concrete well and shelter ................

XII. $A$, Gages on web of Cushing bridge piers; $B$, Cast concrete rings...

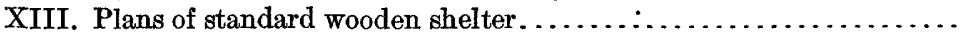

XIV. Plans of California shelter. . . . . . . . . . . . . . . . . . . .

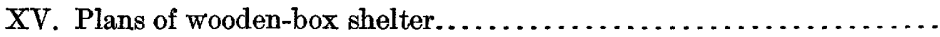

XVI. $A$, Standard wooden shelter, Deerfield River at Charlemont, Mass.; $B$, Wooden-box shelter, Arroyo Hondo at Santa Fe, N. Mex.....

XVII. $A$, Portable gage shelter; $B$, Special Hawaiian shelter, North . Branch of Kaukonahua Stream, Wahiawa, Oahu. ............

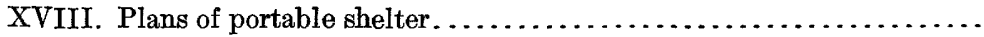

XIX. Plans of plain-concrete house, showing elevations, details of door and window sashes, and iron door and shutters. . .............

XX. $A$, Metal shelter on concrete well, Raquette River at Piercefield, N. Y.; B, Special shelter of stone, Rio Grande at Embudo,

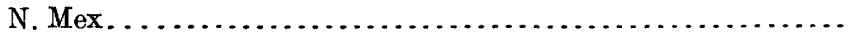

XXI. $A$, Water Resources bench-mark tablet; $B$, Low shelter, Logan

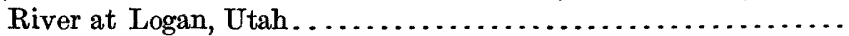

XXII. Automatic-gage shelters: $A$, Feather River at Oroville, Cal.; $B$, North Fork of American River at Colfax, Cal................

XXIII. Automatic-gage shelters: $A$, Tuolumne River at Groveland, Cal.; $B$, Deerfield River at Charlemont, Mass. . . . . . . . . . . . . . .

XXIV. Automatic-gage shelters: $A$, St. Marys River at international boundary; $B$, Chenango River at Chenango Forks, N. Y. . . . . . . .

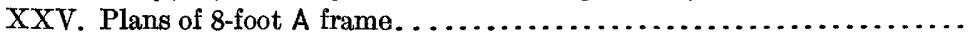


Plate XXVI. Plans of 12-foot A frame. .

XXVII. Plans of 16 -foot A frame. . . . . . . . . . . . . . . . . . . . . . 42

XXVIII. Plans of 20 -foot A frame........................ 42

XXIX. $A$, Standard A frame in place; $B$, Standard cable car. . . . . . 44

XXX. Plans of deadmen and anchorages for cable. . . . . . . . . . . 46

XXXI. Sag diagram for cables. . . . . . . . . . . . . . . . . . . . . 50

XXXII. Plans for standard car............................. 54

XXXIII. Plans for standard footbridge..................... 58

XXXIV. A, Excellent natural control, Black River at Fort Apache, Ariz.; $B$, Artificial control, Sweetwater River at Descanso, Cal.... 58

XXXV. Plans for artificial control. . . . . . . . . . . . . . . . . . . . . . 60

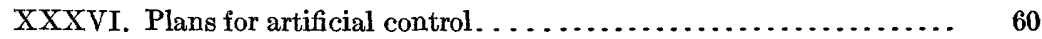

XXXVII. Artificial controls: $A$, San Luis Rey River at Pala, Cal.; $B$, Logan River at Logan, Utah..................... $\quad 60$

Frgure 1. Gage-cutting tool................................. 8

2. Chain-gage equipment. ............................ 9

3. Method of sinking and shoring a well. ................. 17

4. Method of sinking and shoring a well. ................. 18

5. Method of keeping intake clean. . . . . . . . . . . . . . . . . .

6. Method of keeping intake clean. . . . . . . . . . . . . . . . . . 20

7. Automatic gage on Cushing bridge piers ................... 23

8. Oil pipe for float, to prevent freezing. . . . . . . . . . . . . . . 24

9. Floating oil heater, to prevent freezing . . . . . . . . . . . .

10. Plans for trolley for use with ferryboats. ................. 59 


\title{
EQUIPMENT FOR CURRENT-METER GAGING STATIONS.
}

\author{
By G. J. Lron. \\ ITEMS OF EQUIPMENT.
}

Gaging stations for determining the total flow of a stream and its diurnal fluctuation need, in general, the following equipment:

1. A gage or gages for determining fluctuations of stage.

2. Bench marks for referring the gages to a fixed datum.

3. Structures from which discharge measurements are made.

4. Cable and stay line to hold the meter in a vertical position when soundings and velocity observations are made.

5. Graduated lines to indicate the points of measurement.

6. Artificial structures, at places where natural control is ineffective, to regulate the relation between stage and discharge.

Although no one form of any of these items is indispensable, there are certain standard types that can, as a rule, be most economically installed and that not only facilitate the making of observations but insure more accurate results. It is expected that details of construction will be adjusted to local conditions.

The types of equipment that had been found most effective were described in a pamphlet entitled "Plans and specifications for current-meter gaging streams," by C. C. Covert, G. J. Lyon, and C. H. Pierce, issued by the Survey in 1912. The matter presented in that pamphlet has been revised and expanded to include the latest and best available information in regard to the subject, and is embodied in this report, which comprises also suggestions from several hydraulic engineers, to whom acknowledgment is hereby made.

\section{GAGES.}

\section{CLASSIFICATION.}

The instruments that have been used for measuring fluctuations of stage of rivers and other bodies of water may be grouped into two general classes, comprising, respectively, nonrecording gages and recording gages, the grouping depending on the method of obtaining the record, whether by direct readings at stated intervals from a scale board or other device or by some automatic mechanism. 
Recording gages make a record of stage, either continuously by a curve, the coordinates of which indicate the time and the stage, or by a device that prints at regular intervals of time. Nonrecording gages in common use are the vertical-staff gage, the hook gage, the float gage, the chain gage, and the inclined-staff gage.

\section{NONRECORDING GAGES.}

VERTICAL-STAFF GAGE.

The best vertical-staff gage (Pl. I, $A$ and $B$ ) consists of a 2 by 6 inch (or larger) timber, fastened vertically to a rigid support or set upright in a concrete base which is placed in the stream bed below low water. Enameled metal sections (Pl. I, $A, 2$ ) on which the graduations are stamped are screwed to this timber with round-headed brass screws and leather washers. As a substitute for the enameled face a

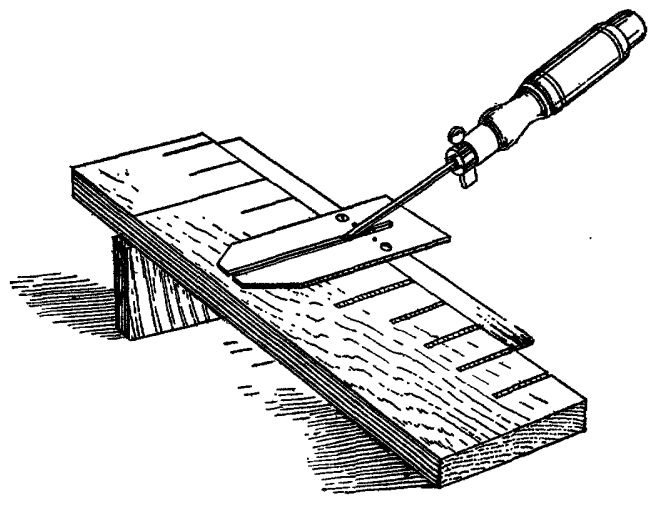

FIGURE 1.-Gage-cutting tool. graduated board may be used, if made in 5 -foot sections of 1 by 4 inch pine, painted white, with Vshaped notches, painted black, clearly indicating all foot and tenth marks (Pl. I, $A, 3$ ). Aspecial tool and guide for cutting the graduations in wooden scaleboards is shown in figure 1. The graduations may also be marked by means of barrel-hoop staples.

A cast-iron face (Pl. I, $A, 4$ ), that is especially desirable where the gage is permanent, is made in foot sections and is marked from 0 to 10 feet by raised figures that are painted either red or white to make them stand out on the black background of the gage. Plate I, $B$, shows a combined vertical and inclined staff gage on Delaware River at Port Jervis, N. Y.

\section{HOOK GAGE.}

A simple form of hook gage (Pl. I, $A, 1$ ) consists of a movable staff, graduated to feet, from 0 downward, with a hook at the bottom, the staff being arranged to slide against a 1-foot New York level-rod scale, which is screwed to a base and is graduated to hundredths of a foot, from 0 upward. The stage is determined by drawing the point of the hook to the surface of the water and reading on the movable staff the foot mark that is opposite the fixed scale from which the tenths and hundredths are read. 


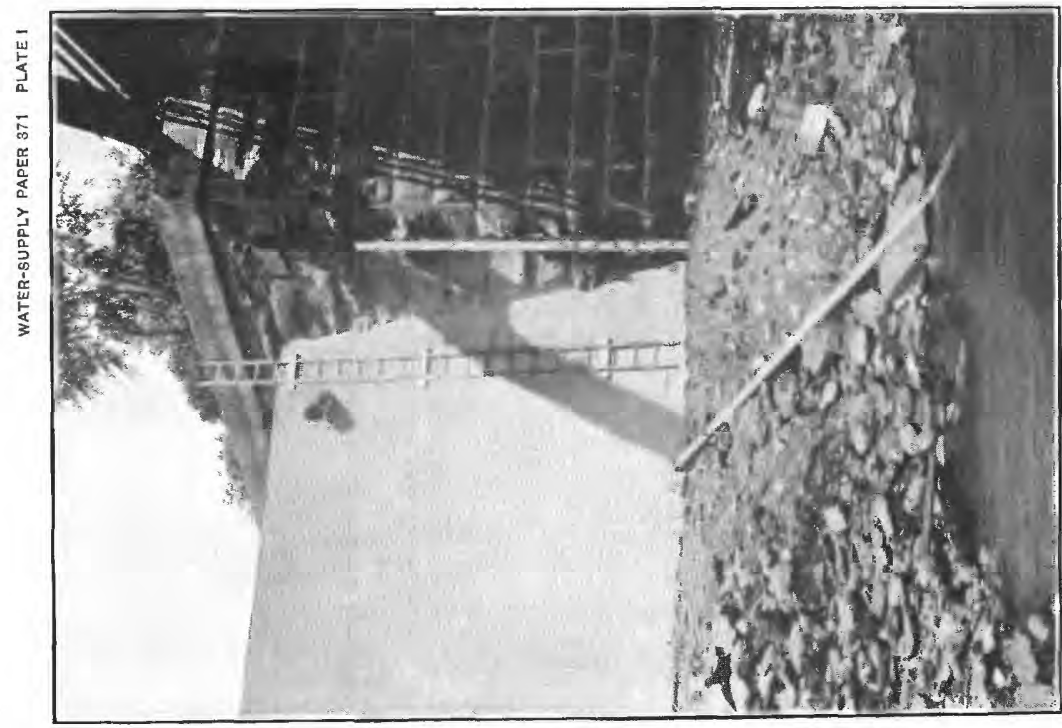

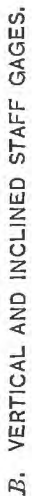

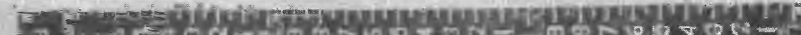

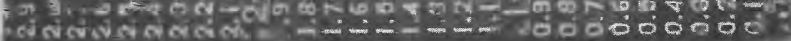

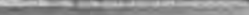

111111111111111111111111111111111

1)

कु

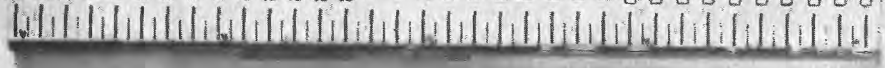

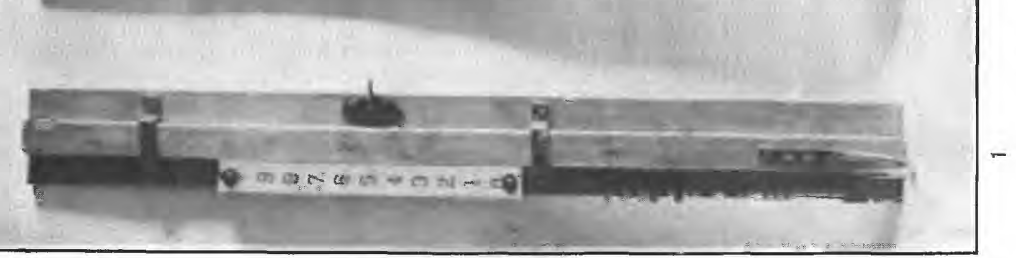


TABLE 1.-Bill of material for standard hook gage.

[Lettered items refer to Plate VIIT, p. 20.]

Item 1. One $\frac{3}{4}$ by 2 inch hook gage rod, of proper length.

2. One.set standard lugs $L$, with $1 \frac{1}{4}$-inch No. 9 brass screws.

3 . One window latch $K$, with screws.

4. One standard hook $Z$, with brass screws.

5. One standard scale $Z 1$, with screws and washers.

6. One piece cypress, or other wood, 2 by 6 inches, for bed piece, for hook gage.

\section{FLOAT GAGE.}

The float gage is similar to the hook gage, except that the book at the bottom of the movable staff is replaced by a float which rises and falls with the fluctuations in stage and carries the staff with it. The readings are made in the manner described for the hook gage.

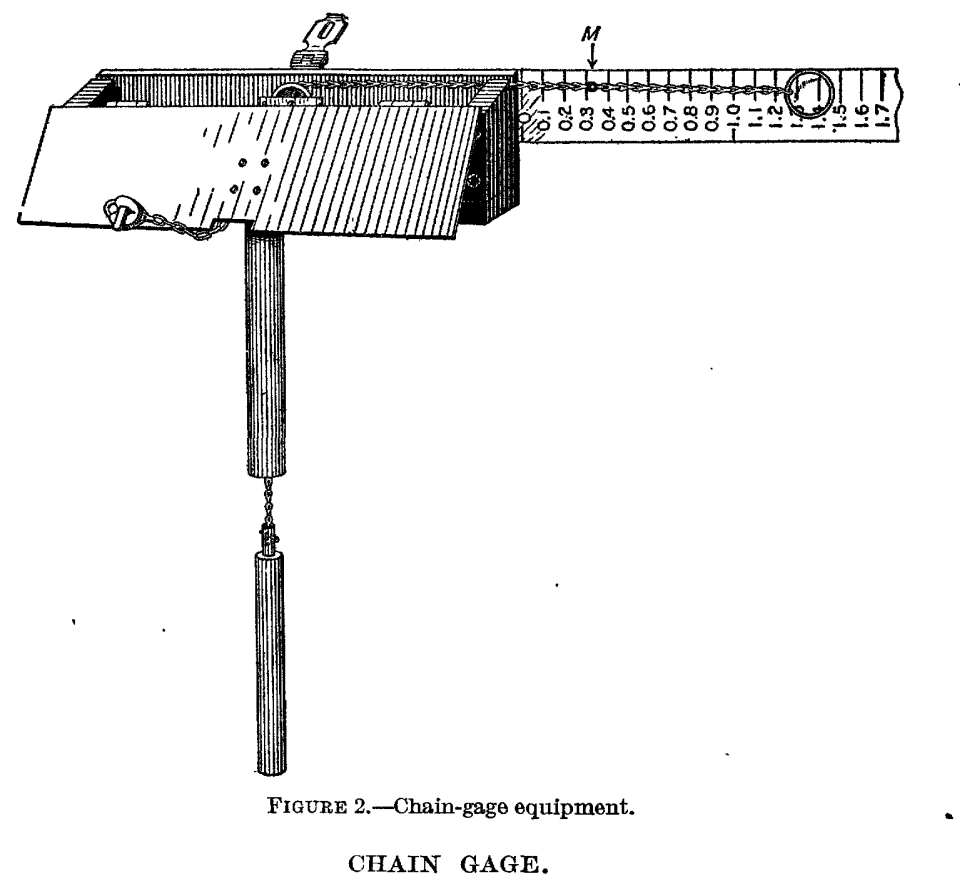

The chain gage, shown in figure 2, consists of a graduated scale 10 feet or more in length, usually either extending from or contained in a box supporting a pulley wheel over which runs a heavy sash chain carrying at one end a weight and near the other end a marker $M$, shown on the scale between the 0.3 graduation and the 0.4 graduation. Sections of the standard enameled metal gage may be used for the graduated scale. This gage as a whole is fastened horizontally to a rigid structure, so that the weight when lowered will come in contact with moving water. When such contact is made the reading on the scale board opposite the marker is recorded. 
The gage weight (Pl. II) is made of an iron bar, 13 inches long, cut squarely off on each end. For a distance of $1 \frac{3}{4}$ inches from one end the bar is turned down to an external diameter of three-fourths of an inch. In the end of this reduced section a half-inch hole is bored to a depth of 3 inches, and, beginning at a point three-eighths of an inch from the end, a series of $\frac{3}{32}$-inch holes are bored along the axis of the weight. These holes are spaced exactly one one-hundredth foot apart, and each hole is placed at an angle of $60^{\circ}$ in plan to the one above it. These holes, which receive the cotter pin by means of which the weight is hung on the sash chain, allow any required adjustment of the chain length by even-hundredths of a foot. The weight should then be well galvanized.

The most satisfactory chain thus far used for gages of this type is Morton's Champion metal window-sash chain No. 1 regular. This chain, if thoroughly stretched before it is put in place, will hold its length and is not sensibly affected by wearing of the parts.

Gage boxes are usually made of first-class cypress or similar wood, with an iron top and down spout. The outside dimensions of the box, as shown in Plate II, exclusive of the top, are as follows: Length, 24 inches; width, 6 inches; height in back, $8 \frac{1}{8}$ inches; height in front, $5 \frac{5}{8}$ inches. The box is fastened together with bolts and screws as shown -8 screws in the bottom (3 on each side and 1 in each end) and 2 screws near the top of the box.

A hole should be bored in the bottom to permit the insertion of a 2-inch wrought-iron pipe, which should be screwed $1 \frac{1}{8}$ inches into the hole in order to fit it and then be removed for convenience in shipping. Two quarter-inch holes, placed as shown on the back piece $B$ (Pl. II), should be made in the back to allow for two positions of the special open-side pulley. The two end pieces $A$ should be notched as shown, so that the chain will run horizontally from the pulley past either end of the box.

The top $E$ is to be made of $\frac{1}{8}$-inch iron with 6-inch strap hinges $G$ and staple for an 8-inch hasp $H$ fastened to it with machine screws. The holes in the cover should be drilled and tapped to match those in the hinges and hasp.

Box and ironwork should receive two coats of mineral paint or Dixon's graphite paint, both inside and out.

The materials required are specified in Table 2.

TABLE 2.-Bill of material for chain-gage box.

[Lettered items refer to Plate II.]

LUMBER.

Item 1 . One piece cypress, $1 \frac{1}{8}$ by 8 inches by 8 feet long, from which cut-

Two pieces $A$, ends, $3 \frac{3}{4}$ by $6 \frac{1}{4}$ inches.

One piece $B$, back, 7 by 24 inches.

One piece $C$, front, 5 by 24 inches.

One piece $D$, bottom, 6 by 24 inches. 

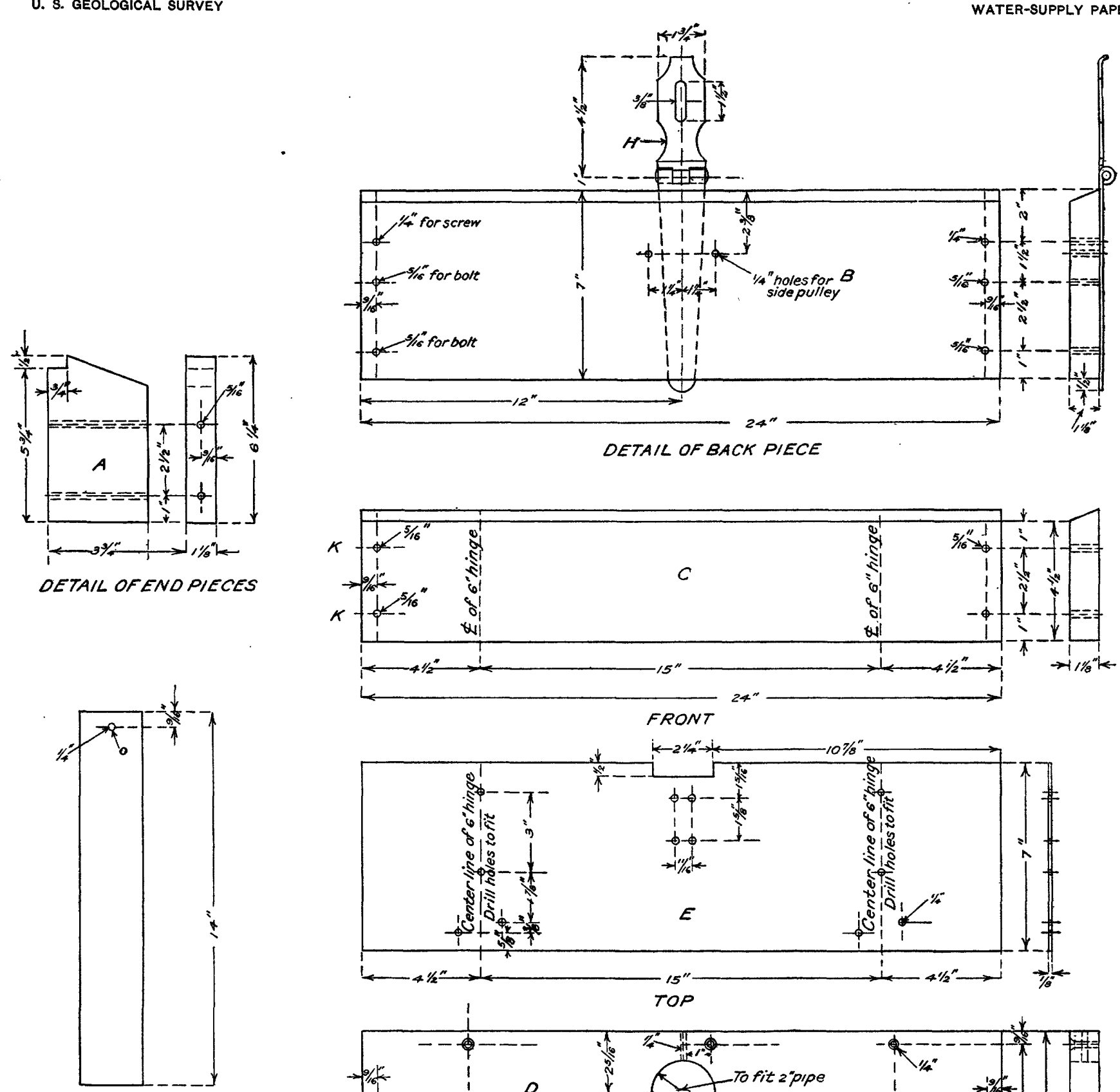

2"IRON PIPEL

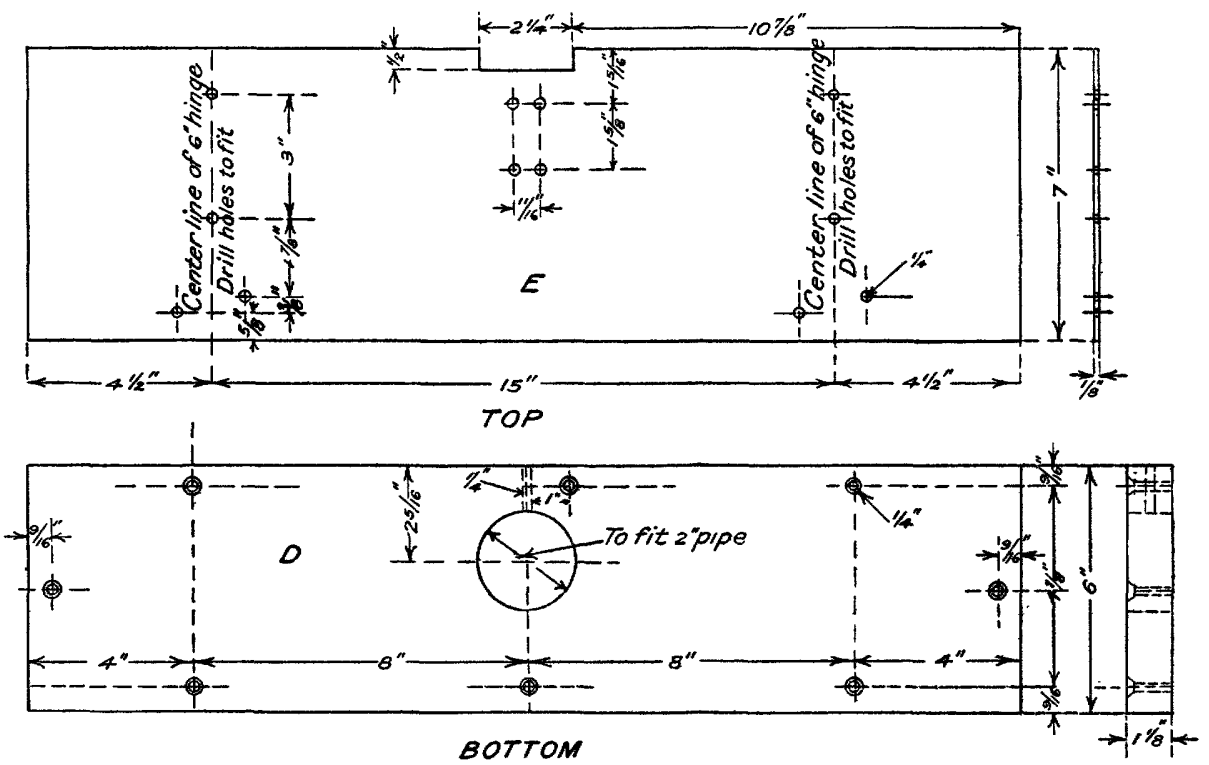

PLAN OF CHAIN-GAGE BOX AND WEIGHT.

Bill of material given in Table 2, page 10 .

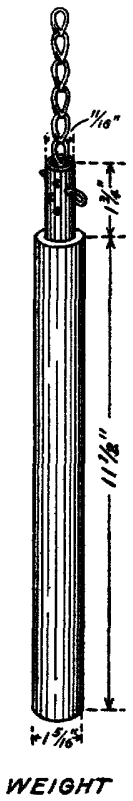


IHARDWARE.

Item 2. One piece sheet iron $E$, top cover, $\frac{1}{8}$ by 7 by 24 inches.

3. Twelve flat-head machine screws, $\frac{1}{4}$ by $\frac{1}{4} \mathrm{inch}$.

4. One pair 6-inch strap hinges $G$, with 1-inch screws.

5. One 8-inch safety hasp $H$ and staple $I$, with 1-inch wood screws.

6. Four carriage bolts $K, \frac{1}{4}$ by $6 \frac{1}{2}$ inches, with nuts and washers, ends to be cut and riveted flush with nuts.

7. One piece 2 -inch wrought-iron pipe $L, 14$ inches long, threaded one end.

8. Ten F. H. bright wood screws $N, 2$ inches by No. 12.

9. One stove bolt $O, \frac{1}{4}$ by $1 \frac{3}{4}$ inches, round head, for holding pipe to bottom of box.

10. One open-side pulley.

\section{INCLINED-STAFF GAGE.}

ESSENTIAI FEATURES.

The inclined staff ( $\mathrm{Pl} . \mathrm{I}, B$ ) is useful where there is no rigid object to which a vertical staff may be attached. It should be made of 4 by 6 inch timber, or larger, supported at short intervals on posts or concrete piers firmly set in the ground, and should be graduated by means of an engineer's level after being placed in position, so as to give readings directly.

\section{GAGE ON CONCRETE PIERS.}

The general method of installing gages on concrete piers is shown in Plate III by the profile of the river bank.

The bed pieces should be 4 by 6 inches by 12 feet, of chestnut, fir, or other timber equally suitable for the work. The top of the bed pieces should be flush with the original surface of the ground, so as to offer the minimum obstruction to ice and drift. The gage rod should be of 1 by 4 inch spruce or similar wood. The life of the timber pieces may be lengthened materially by the use of carbolineum or creosote,-applied hot.

In order to afford drainage and thus to minimize the danger of the gage being disturbed by frost, the soil for a foot below and on each side of the bed piece may be removed and replaced with small stones.

Piers should reach below the frost line, and should be placed 11 feet on centers, slope measurement, thus allowing a lap of 6 inches on each end of the bed pieces. These lap joints should be so framed as to allow changes in the slopes of the bank. They should be bored for $\frac{3}{4}$-inch anchor bolts and the top piece should be countersunk so that the nut, using flat washers, and the end of the bolt will lie below the gage rod. The bolts should be of $\frac{3}{4}$-inch iron, 18 inches long, the hook being 3 inches long.

The bolts should be placed in the bed pieces, which are laid over the holes for the piers, and the concrete then filled in up to the bed pieces and allowed to set before any work is done on the rods or bolts. This part of the pier should be left rough, and in addition a few spikes 
should be stuck into the concrete to insure a bond when the top of the pier is finished, in accordance with the drawings, after the gage rod is in place. When the concrete is hard the nuts should be screwed down and the gage put in place with screws, breaking joints with the bed pieces.

The proper foot marks and subdivisions to indicate the water stage should be located on the rod by means of an engineer's level and should be referred to the station bench mark. Feet of elevation along the rod should be divided into tenths and quarter-tenths and marked by barrel-hoop staples; $1 \frac{1}{2}$ inches long for the foot marks, 1 inch long for the tenth marks, and one-half inch long for the quarter-tenth marks, or by brass-headed tacks. Pattern numbers should be used to indicate the proper marking of the foot and tenth marks. The entire length of the gage may be subdivided into quarter-tenths, or only that part of it which is required to be so divided by the table of limits for the station.

The piers may be built of 1-3-5 concrete, without forms, and should be circular in cross section. Type A or type B may be used, the type selected depending on the nature of the soil. The material required for each installation is shown in Table 3.

TABLE 3.-Bill of material for inclined gage on concrete piers.

Item 1 . One bed piece 4 by 6 inches by 12 feet for each section.

2. One gage-rod piece 1 by 4 inches by 12 feet for each section.

3. One piece $\frac{3}{4}$-inch iron, 18 inches long, threaded one end, 3-inch hook on other end, for each pier.

4. One $\frac{3}{4}$-inch flat washer for each pier.

5. One $\frac{3}{4}$-inch nut for each pier.

6. Six 2 -inch No. 12 wood screws, round head, brass, for each gage-rod section.

7. - numbers for foot marks.

8. - screws for each number.

9. - barrel-hoop staples $1 \frac{1}{2}$ inches long.

10. — barrel-hoop staples 1 inch long.

11. - barrel-hoop staples $\frac{1}{2}$ inch long.

12. - cubic yards concrete for piers.

13. carbolineum for timber.

GAGE ATTACHED TO TIMBER POSTS.

The method to be followed in constructing gages on timber posts is similar to that described for gages on concrete piers, the bed pieces being carried as shown in the drawing for timber anchorage for slope gages.

The supports should be bolted to the sills and the frame, then placed in the trenches at the proper distances. The bed pieces should then be bolted to the 2 by 4 inch supports, as shown in the drawing, after which the backfill should be thoroughly tamped into place. If desired, a $\frac{1}{4}$-inch bolt may be placed in each side parallel to the bed pieces through the upper end of the 2 by 4 inch supports. The material required is listed in Table 4. 


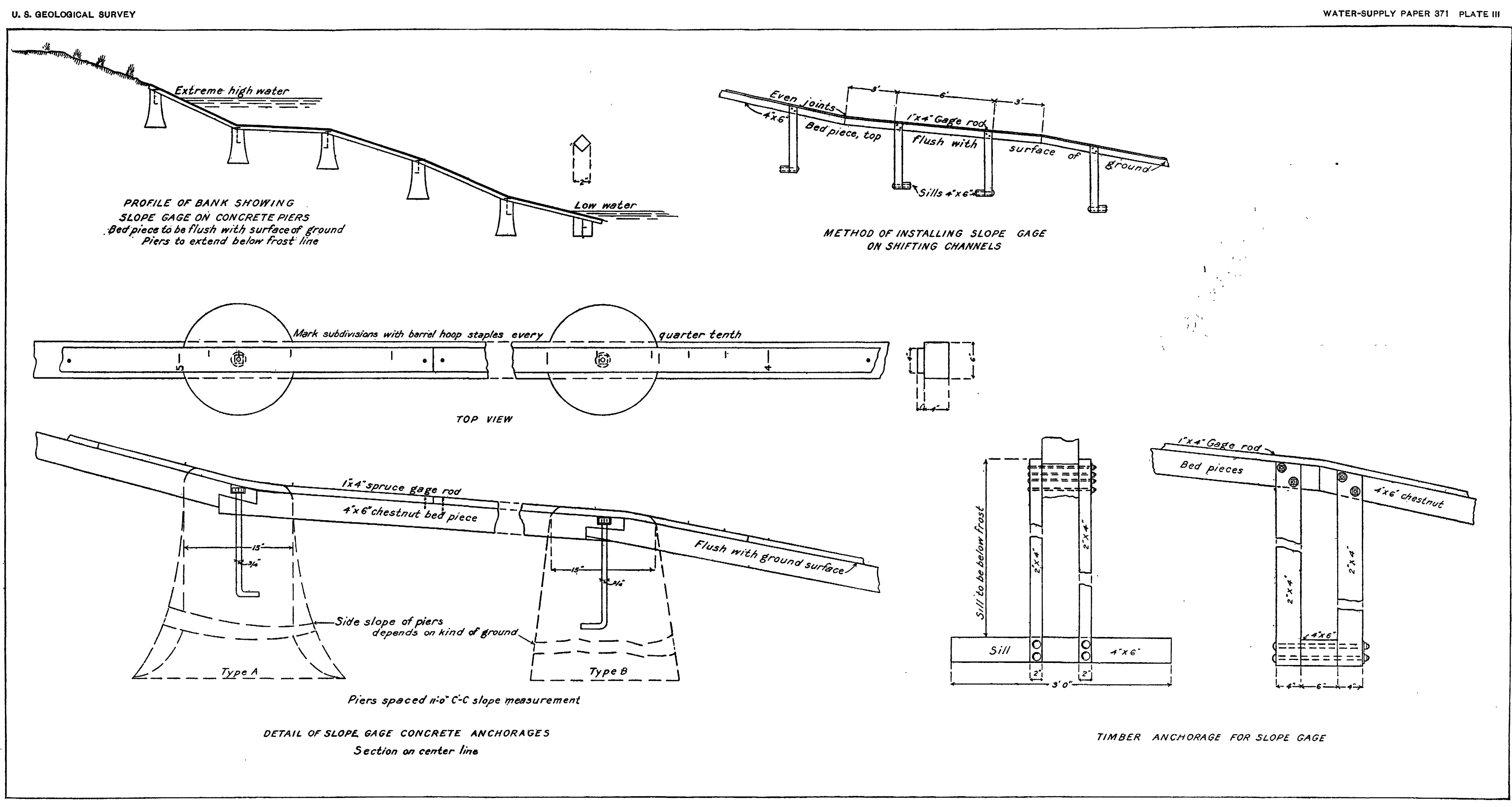


TABLE 4.-Bill of material for inclined gage on timber posts.

Item 1. One bed piece 4 by 6 inches by 12 feet for each section.

2. Gage-rod piece 1 by 4 inches by 12 feet for each section.

3 . Four bolts $\frac{1}{2}$ by $14 \frac{1}{2}$ inches, with washers and nuts, for each section.

4. Four bolts $\frac{1}{2}$ by $10 \frac{1}{2}$ inches, with washers and nuts, for each section.

5. Six 2-inch No. 12 wood screws, round head, brass, for each section.

6. - numbers for foot marks.

7. - screws for numbers.

8. - barrel-hoop staples $1 \frac{1}{2}$ inches long.

9. - barrel-hoop staples 1 inch long.

10. - barrel-hoop staples $\frac{1}{2}$ inch long.

11. Four pieces 2 by 4 inches by distance below frost for each section.

12. One sill 4 by 6 inches by 3 feet for each section.

13. Carbolineum for timber.

Note.-The plan shows the support for the intermediate joints. At the extreme end of the gage, whether one or more sections are used, only one set of 2 by 4 inch uprights are necessary, and the bolts that fasten these to the sills are $\frac{1}{2}$ by $10 \frac{1}{2}$ inchesthat is, 4 inches shorter than for the intermediate section. One more sill than the number of sections is required.

If the gage is to be installed where the stream channel is subject to material change in cross section the inclined gage on timber posts may be used, but the construction should be modified as shown in Plate III, illustrating the method of installing slope gage on shifting channels. Each section of the gage should be an independent unit, so that the minimum of reconstruction will be necessary if the gage is washed out. Two instead of four 2 by 4 inch uprights should be attached to each sill, and two sills instead of one should be provided for each intermediate gage section. The only change from Table 3 in the list of material required is the addition of an extra sill for each intermediate section.

\section{RECORDING GAGES.}

\section{ESSENTIAL FEATURES OF INSTALLATION.}

The essential parts of the recording gage are: (1) A float which rises and falls with the surface of the water; (2) a device for transferring the vertical motion of the float to the record, either directly or through a reducing mechanism; (3) the recording device; and (4) the clock. Plate IV shows types of automatic gages.

A properly installed automatic gage will give a record whose accuracy depends solely on the refinement of the instrument, but results from the best of gages will be impaired by improper installation. Much care in installation is therefore essential, and if the gage is to record stream heights during the winter and at flood stages it must be protected from freezing and from floating ice and débris.

In installing an automatic gage it is necessary to provide (1) a well for the float and an intake pipe to connect the well with the river; 
(2) a house to shelter the gage; and (3) staff or hook gages referred to permanent bench marks for use in checking the record and maintaining the datum.

In the ideal installation, illustrated in Plate $\mathrm{V}, A$, the well and the house are far enough back from the river to be out of danger from floating ice or drift and to prevent freezing of well and pipes; a permanent ladder extending to the bottom of the well affords ready means of inspecting the float and intake pipe; the well is lined with concrete or heavy plank; the intake pipe is well below the lowest stage of the river and is provided with a screen for keeping out fish and foreign material, and where the intake pipe enters the well a valve is provided, so that the flow can be reduced if necessary to eliminate wave action; and ventilators from the well and in the gable of the roof keep house and well free from moisture. One nonrecording gage, of the type best suited to the locality, is placed in the river, on a solid foundation in the same cross section of the river as the intake pipe, and another, preferably a hook gage, is placed in the float well to aid in setting and checking the recording gage and, by comparison with the river gage, to indicate any interruption in the free communication with the river. The river gage may be dispensed with by using a reference point by means of which the elevation of the water surface can easily be determined.

Under ordinary circumstances a single intake pipe is sufficient; but where there is a possibility of a single intake being buried a series of pipes, one above the other, may be installed within the range of high and low water. On certain streams carrying silt in large quantities it has been found necessary to eliminate the intake pipe, the water entering the well as shown in Plate V, $B$, and natural cover protecting the well in the manner illustrated.

\section{WELL AND INTAKE.}

\section{MATERIALS AND DIMENSIONS.}

The well is essentially a stilling box for the float, and it is so connected with the river by an intake pipe that the height of water in the well fluctuates with the stage of the river. The well box must be large enough to accommodate the float, the driving and counter weights, and the hook or staff gage and to permit them to be inspected readily. A well that extends underground more than 8 feet should have an inside cross section of at least 12 square feet in the clear. Inside dimensions of $2 \frac{1}{2}$ by 6 feet or 3 by 4 feet have generally been used and have been found satisfactory. A smaller cross section, however, will serve if the well box is shallow or if it is attached to the side of a cliff $(\mathrm{Pl} . \mathrm{V}, B)$, when several entrances between high and low water should be provided. 


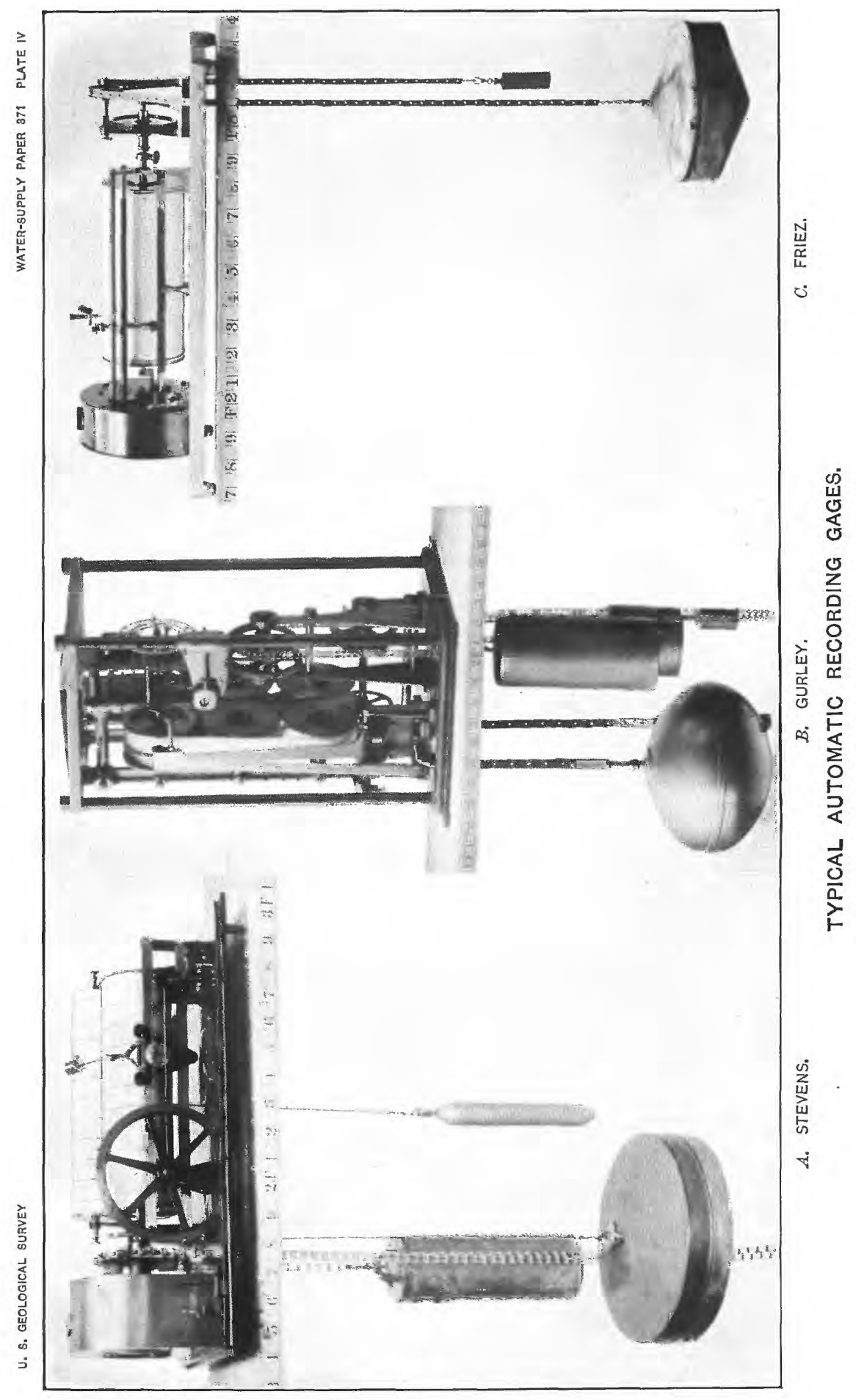




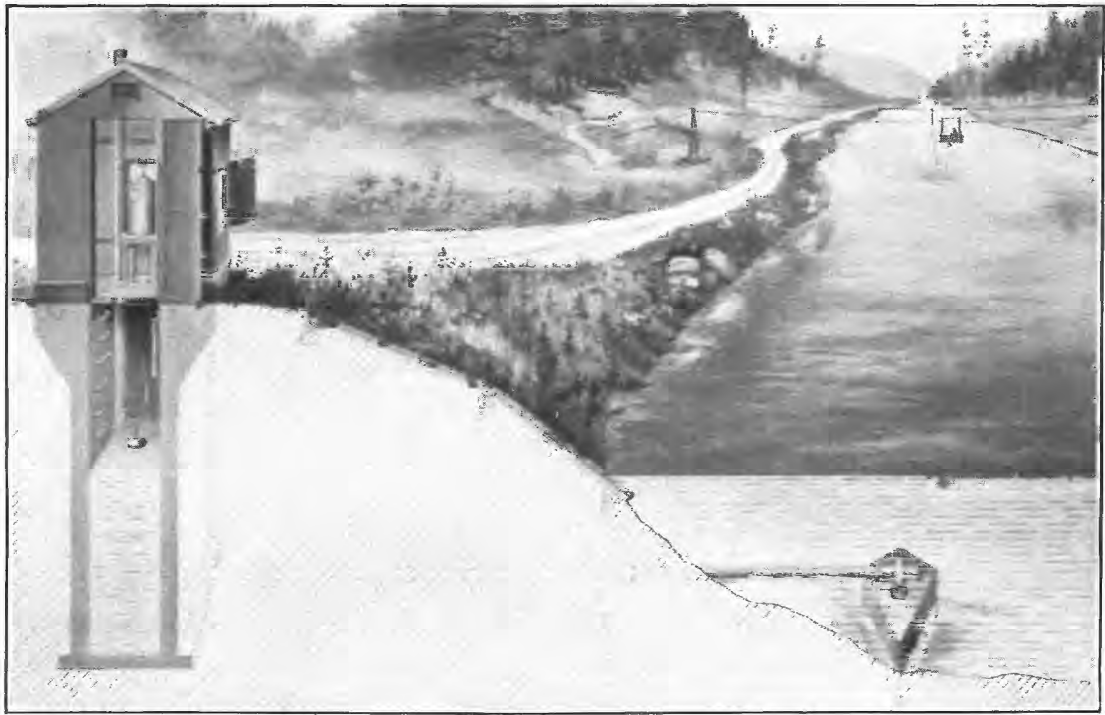

A. TYPICAL GaGing STATION, WITH aUtOMATIC GaGe.

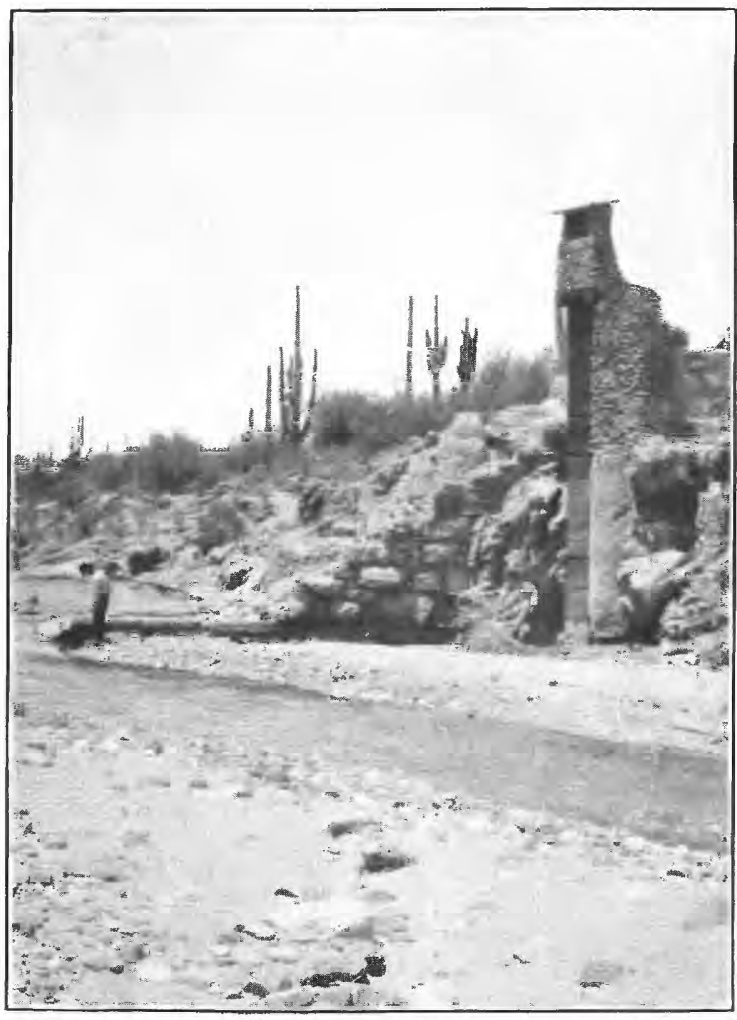

B. WELL WITH NO INTAKE AND WITH SHELTER OF BOX TYPE. Agua Fria River at Glendale, Ariz. 
The material suitable for lining the wells includes timber (usually treated with a wood preservative), brick, vitrified-tile pipe, concrete, plain or reinforced in mass, concrete rings, stone, cast-iron pipe, and galvanized wrought-iron culvert pipe. The general choice of the material to be used at any station depends on the probable length of the useful life of the station, more durable material being required at stations of expected long usefulness. The specific choice will. depend on the accessibility of the station and the availability of labor and material.

To fulfill its purpose of providing a free connection between the stream and the well, the intake should be placed in such position on the stream bed that it will always be covered by water.

For the ordinary station galvanized wrought-iron pipe makes the best intake and under usual conditions will last 10 or 15 years. For stations to be maintained permanently cast-iron pipe, which may be expected to last 40 or 50 years, makes the most durable and substantial intake. Two, three, or four inch pipe has been used, but 4-inch pipe is preferable for ordinary conditions; for heavy silting streams 10 or 12 inch corrugated iron pipe has been found advantageous. Intakes could also be built of vitrified tile, of spiral-riveted corrugated wrought-iron, or of universal or steel-banded wooden pipe.

If cast-iron intake pipe is used, the joints, which are under no great pressure, may be made tight by casting a strip of lead a quarter of an inch thick, an inch wide, and equal in length to the circumference of the pipe, and then driving it home cold with a calking tool. Intakes laid under water also may be sufficiently well calked by this method.

\section{METHODS OF CONSTRUCTION.}

TIMBER-IINED WELLS.

Excavations for well and intake are commonly made in one operation by the open-trench method, the material being dug out in benches and shoveled into wheelbarrows, which are then run out toward the stream and dumped. Shoring is put in wherever there is any possibility of caving, and as the excavation approaches the water surface the stream is kept out of the trench by a plank cut-off put at the river end, supplemented, if necessary, by sand bags and clay. The excavation must be carried down below lowest water, so that the intake will always be submerged. The well having been dug, the bottom should be leveled, and prepared to receive the floor of the well box.

Plans for a timber well box, $2 \frac{1}{2}$ by 5 feet inside dimension, are shown in Plate VI. Its longest cross-sectional dimension should be placed in the direction of the intake pipe. The sides are built of planks ( $T 1 T_{2} T 3, \mathrm{Pl}$. VI) at least 2 inches thick; spiked to the 
frames $W$ and $V$. The bottom $X$ is of similar material. The top of the well lining should be tied in by the collars $F J$. The pieces $F J N$ should be set level and flush with the top of the lining at the elevation of the bottom of the floor, which should be a few inches above the ground surface to facilitate drainage. The piece $F$ should be placed across the end of the well just below the pieces $J$. The 2 by 6 inch supports should be spiked or bolted below the pieces $F$, but along the sides of the well. The pieces mentioned, together with the sills $G$, placed on top of and at the ends of $F$, carry the shelter, which is bolted to them: It is essential that the floor of the building carrying the gage table should be rigidly attached to the well lining.

A ladder with side pieces of 2 by 4 inch material $(S 2)$ and 2 by 4 inch rungs $(S 3)$ should be spiked to the inside of the lining and arranged as shown, to give easy access to the hook gage and bottom of the well. The hook gage should be placed on the bed piece $U$, so as to be in the light entering the well from the trapdoor.

The timber used in the well should be treated with a preservative. A list of material for this timber well is given in Table 5 .

TABLE 5.-Bill of material for standard timber well box.

[Lettered items refer to Plate VI.]

LUMBER, ROUGH.

Item 1. Four pieces 2 by 4 inches by 14 feet ( 36 feet b. m.), from which cut-

Two pieces $F$, sills, 5 feet long.

'Two pieces $G$, sills, 6 feet long.

Twa pieces $N$, top frame inside, 2 feet long.

Two pieces $N 1$, top frame inside, 5 feet long.

Two pieces $J$, top collar outside, 6 feet long.

2. Four pieces 2 by 6 inches by 12 feet ( 48 feet $\mathrm{b}: \mathrm{m}$.), from which cut-

Two pieces $S$, supports, 6 feet long.

Six pieces $X$, floor of well.

3. Six pieces 2 by 6 inches by 10 feet ( 60 feet b. m.), from which cut floor boards and trapdoor.

4. Twenty-six pieces 2 by 6 inches by depth of well, being-

Twenty pieces $T 1$, sides.

Six pieces $T 2$, ends.

5. Four pieces $T 3$, ends, 2 by 8 inches by depth of well.

6. - pieces 4 by 4 inches by 14 feet, from which cut-

- pieces $V$, braces, 5 feet long.

- pieces $W$, braces, 2 feet long.

7. _- pieces 2 by 4 inches by depth of well, from which cut-

- pieces $S 2$, ladder poles.

- pieces $S 3$, ladder rungs.

Note.-The cutting scheme shown in the table should be followed carefully. It is customary in construction work in the field to make a reasonable increase in bills of lumber to allow for cuts, undersized pieces, and mistakes. 


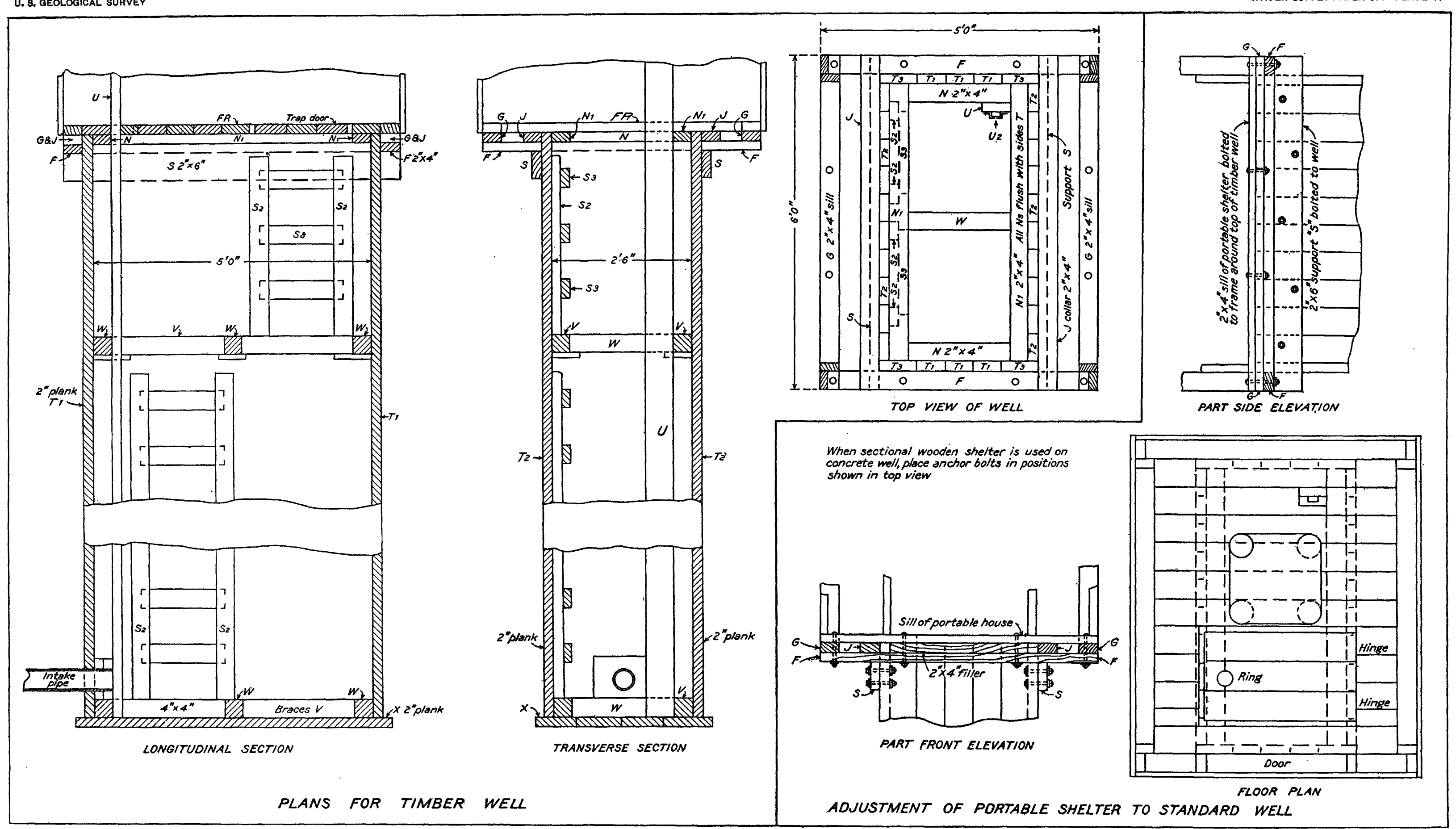

PLANS OF STANDARD TIMBER WELL BOX. 
HARDWARE.

Item 8. Hinges and lifting ring for trap door.

9. - pounds $4 \frac{1}{2}$-inch wire nails (30d.).

10. - pounds 4-inch wire nails (20d.).

11. Intake pipe, anchor, etc.

12. One standard gage table (Table 15, p. 38).

13. One standard hook-gage outfit (Table 1, p. 9).

The floor of the timber well box is placed in position first, with the lower braces $V W$ nailed to it, either before or after the floor is put in place. Then the sides, which have been built in separate sections, spiked to the proper cross braces, with the opening for the intake pipe ready, are lowered into their proper positions and all are fastened together. The outside joints of all timber well boxes should be battened to prevent silting. To keep out very fine silt it is desirable to place battens inside as $A$ well as outside.

In some places it is advantageous to have the well box built and treated with preservative at a carpenter shop and then hauled to the work, although shallow well boxes may be built on the bank and then lowered into the excavation in one piece. In lowering the well box a set of temporary shear legs, rigged with a tackle, should be used.

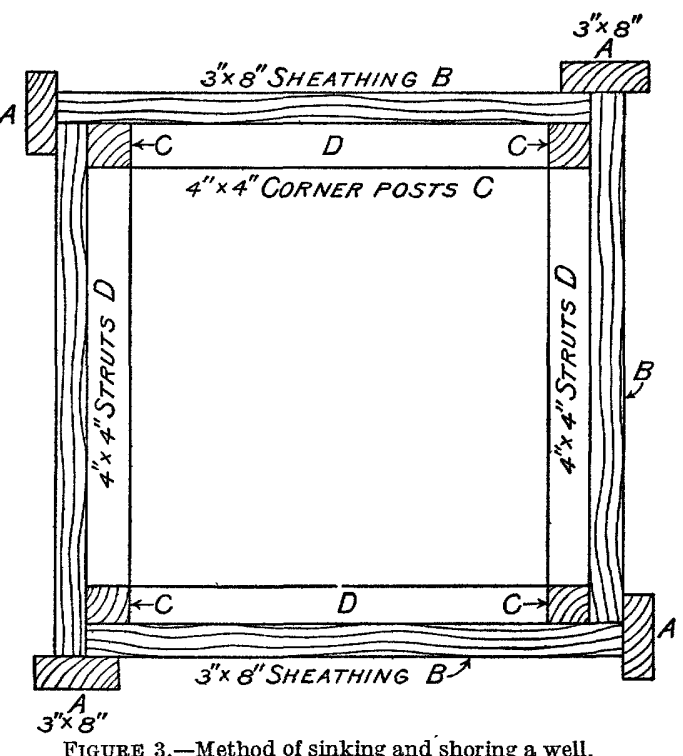

If the ground contains no bowlders, a timber well box may be built by the well-known open-crib foundation process. By this process the sides of the well are built in sections about 6 feet long and securely fastened together. A hole 2 or 3 feet deep is dug at the site selected and a section of the well lining is placed vertically in the hole. The material is then excavated from within the well, the lining sinking and new sections being added as the excavation progresses. Care must be taken to keep the structure plumb. This method obviates the necessity of shoring. The floor is placed at the proper depth, and the intake is built by the open-trench method.

A successful method of putting down a well box and at the same time providing adequate shoring is illustrated in figure 3. The excavation is started in the ordinary manner and the corner posts $A$ are $97886^{\circ}$-WSP $371-15-2$ 
driven in such a relation to each other that the sheathing pieces $B$ will form the lining of the completed well box. . One end of each piece $B$ abuts against post $A$, and is toenailed; the other end rests on the opposite post $A$, and is spiked to it. As the excavation progresses sheathing is added at the bottom until the well is of the desired depth, when corner pieces $C$ are inserted to finish the well box. If more than one section is required to attain the requisite depth, the

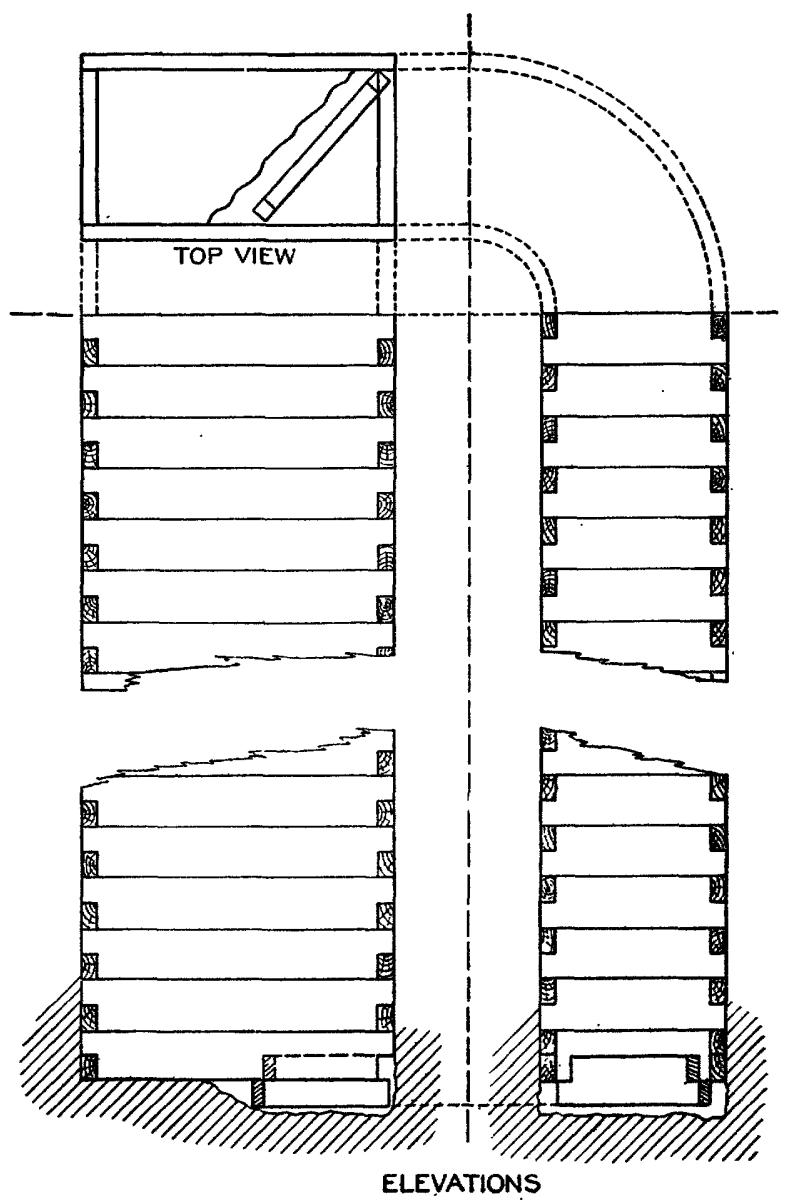

FIGURE 4--Method of sinking and shoring a well.

dimensions of the lower section should first be decided upon, and those of each upper section adjusted so as to encompass the section immediately below.

Another feasible method of constructing a timber well in earth, especially in places where it may be desirable to tunnel between the well and the stream, is shown in figure 4. By this method the shoring is applied section by section at the bottom of the well as the excava- 

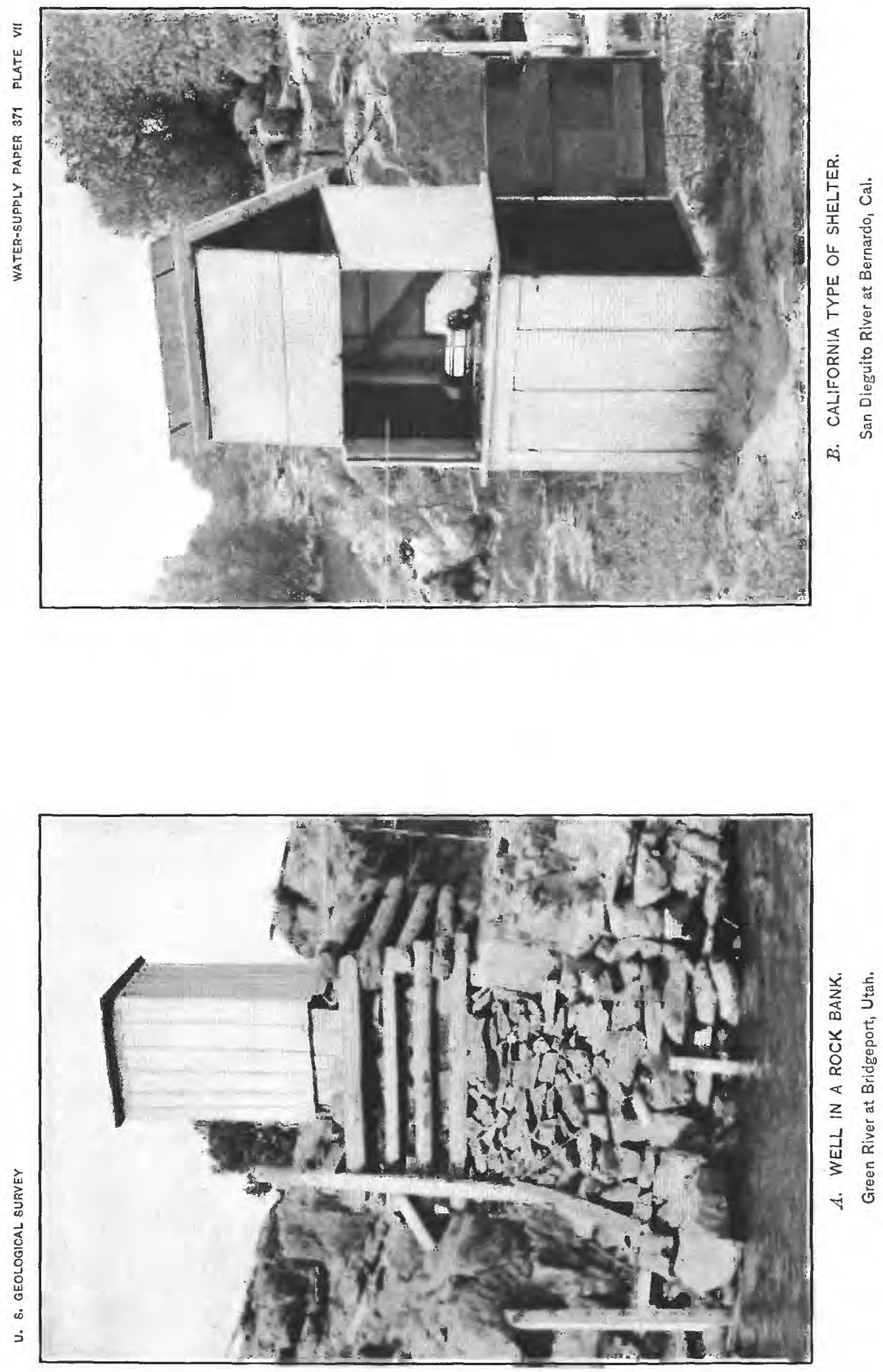
tion proceeds. The sections used are built of four pieces of plank sawed according to templets in the manner shown (fig. 4). The manner of placing three sides of the planks is evident; the fourth plank is placed by deepening the excavation by the width of half a plank and swinging the plank outward and then upward from below. The sections are held in place by the earth pressure, and the excavation at any stage need never be more than the width of half a plank ahead of the timbering. The vertical alignment is preserved by using a carpenter's level or a plumb bob. The well may be finished by spiking fast corner posts and putting in the middle braces and the usual ladder.

A successful method of constructing a well in a rock bank is shown in Plate VII, $A$.

ANCHORAGE FOR INTAKE PIPE.

In rivers carrying ice, logs, or drift the river end of the intake should be securely fastened to an anchorage to prevent its displacement. Deposits may be avoided by so shaping the anchorage that it will not decrease the velocity of the passing water.

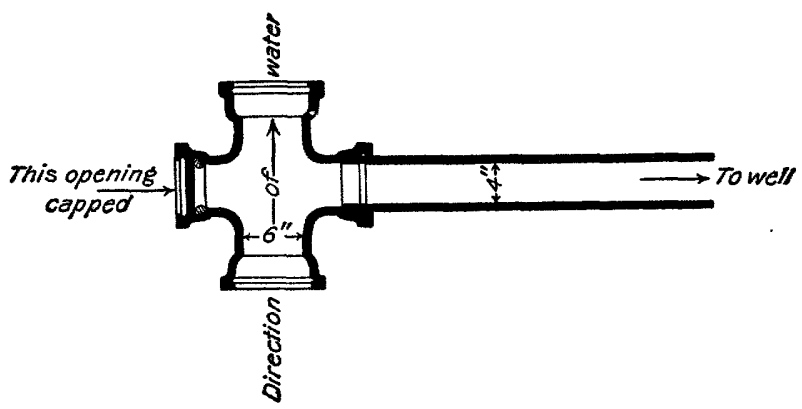

FIGURE 5.-Method of keeping intake clean.

The anchorage may be constructed at times of low water by depositing concrete under water in a simple box form on the stream bottom. No current should be allowed to flow through the form. It may be an advantage to incase quick-setting concrete in paper bags to prevent the cement from washing away.

Where it is necessary to use a cofferdam to install the anchorage the work should be done at favorable stages of the stream and completed as rapidly as possible, precautions being taken against a sudden rise. It is usually economical to provide a power pump at the beginning for removing the water from the cofferdam during construction.

In streams carrying silt, drift, or manufacturing wastes the end of the intake may be made to a certain extent self-cleansing by the method indicated in figures 5 and 6 . If the pipe becomes clogged it may be cleaned by means of jointed rods pushed through from the well end, or by a chain drawn back and forth, or by' a water jet. The 
river end of the intake pipe should be fitted with a $T$ or cross over the anchorage, as shown in Plate V, $A$ (p. 15), and in Plate VIII, and with a screen to prevent the entry of fish, and the well end should have a vatve or other means of closing the intake.

PLAIN AND REINFORCED CONCRETE WELLS.

Plain concrete is suitable for wells of moderate depth set well back in the bank. The plan on Plate VIII brings the length of the house along the line of the trench for the intake pipe, the width of the house being such that it can be built in practically the width of the trench. This design also allows room for the use of rods for cleaning the intake.

The well should be built to the surface of the ground to furnish a foundation for the shelter. The walls of the well should be of a

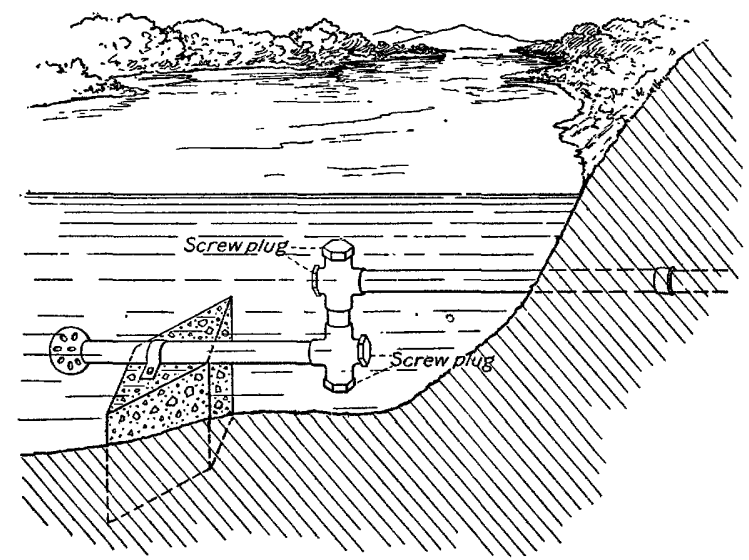

Figure 6.-Method of keeping intake clean.

proper thickness for the depth, due consideration being given to the nature of the material passed through. Three feet from the top of the well the sides should be corbeled out to the dimensions shown on the plan. In localities where the ground freezes to a great depth it may be advisable to begin corbeling at a greater distance below the frost line. If used with a standard timber shelter, the well should be finished to the dimensions shown in Plate IX, top view of well, and the necessary anchor bolts set as indicated.

To construct the plain-concrete well use the material specified in Table 6.

TABLE 6.-Bill of material for plain-concrete well supporting a standard timber shelter.

[Letiered items refer to Plate VIII.]

Item 1. 2.7 cubic yards 1-2-4 concrete for upper 3 feet of well, requiring-

17 bags cement.

$1 \frac{1}{4}$ yards sand.

$2 \frac{1}{2}$ yards stone. 


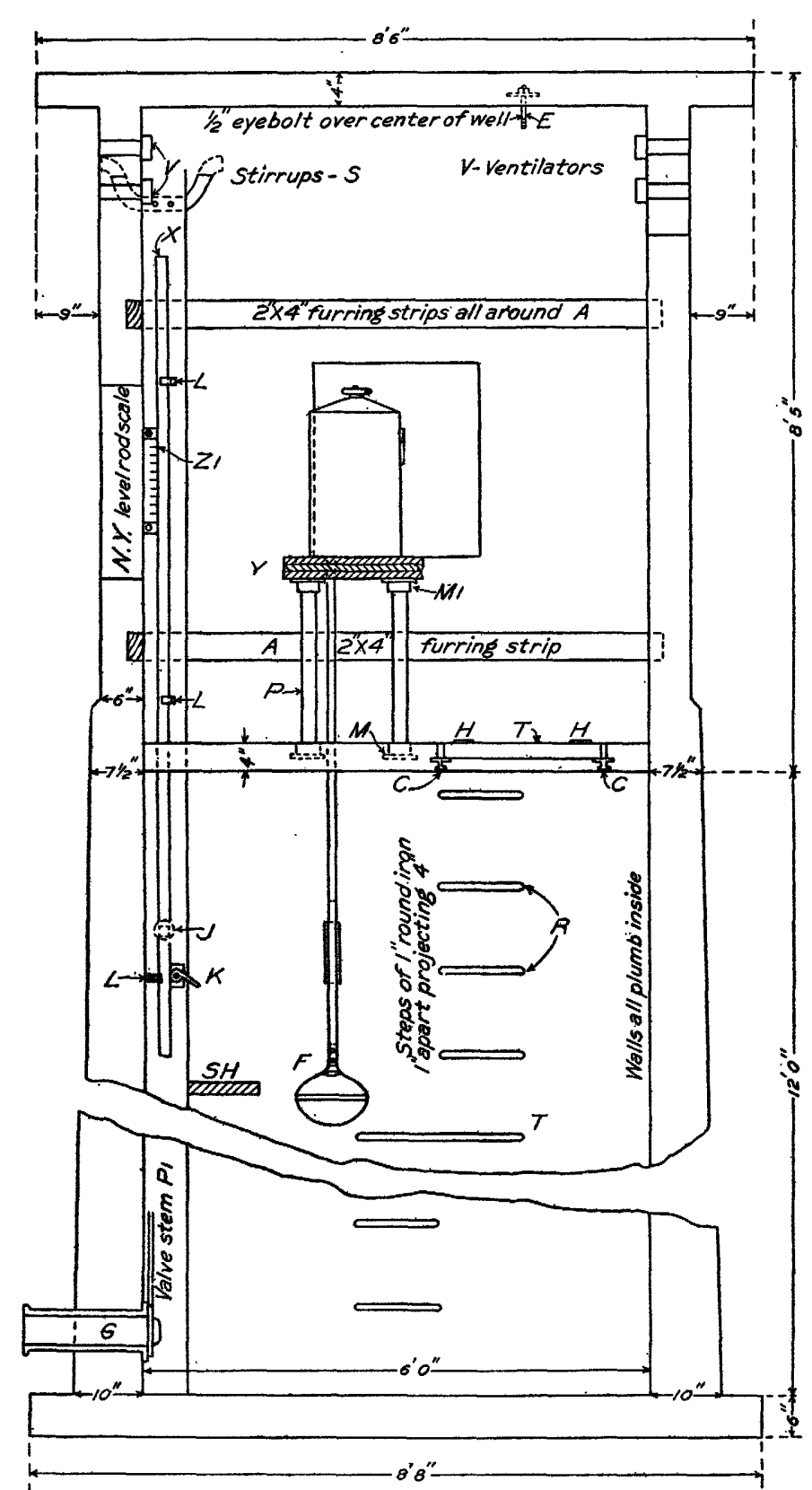

LONGITUDINAL SECTION ON CENTEA LINE

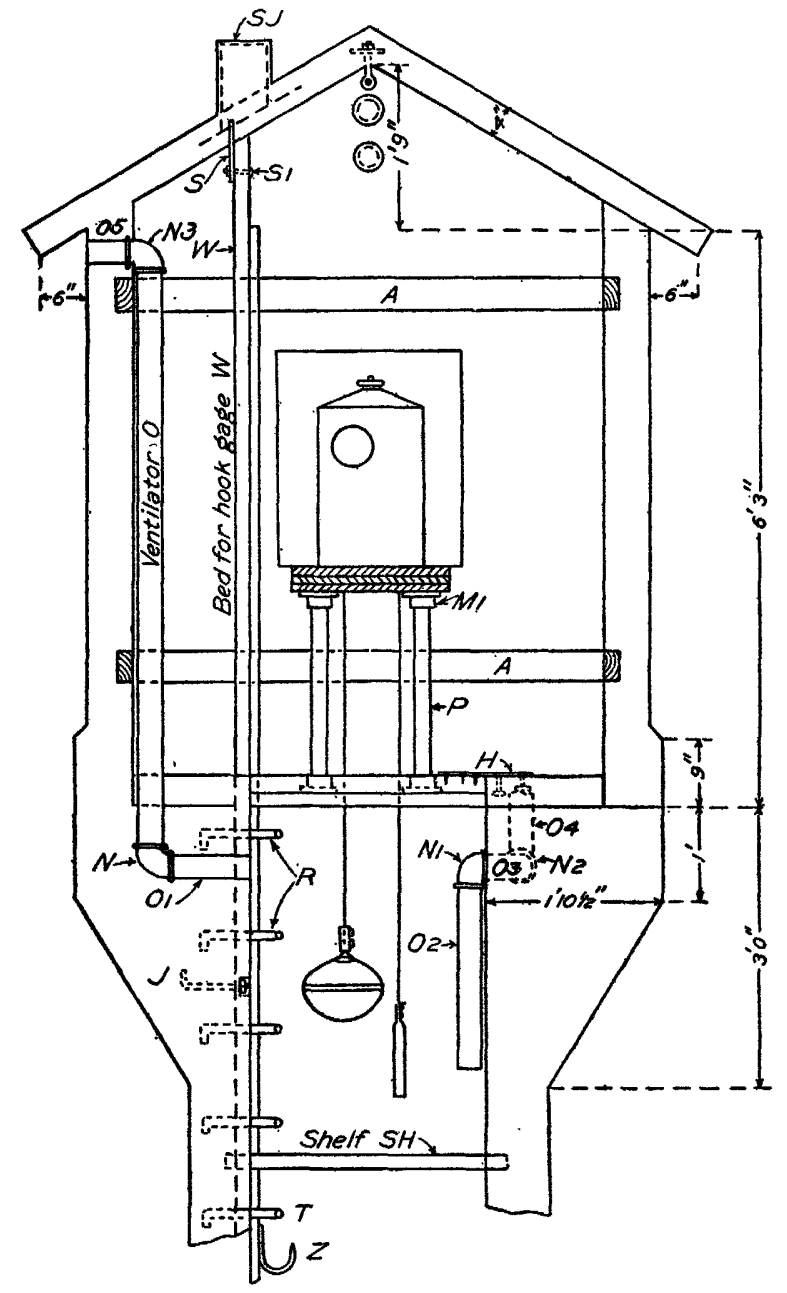

TRANSVERSE SECTION ON CENTER LINE

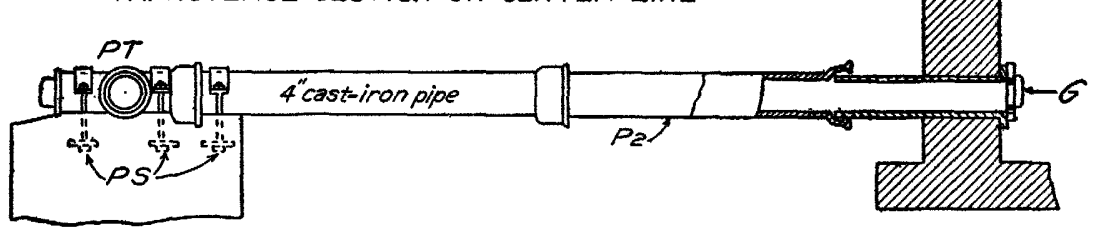

INTAKE PIPE AND ANCHOR

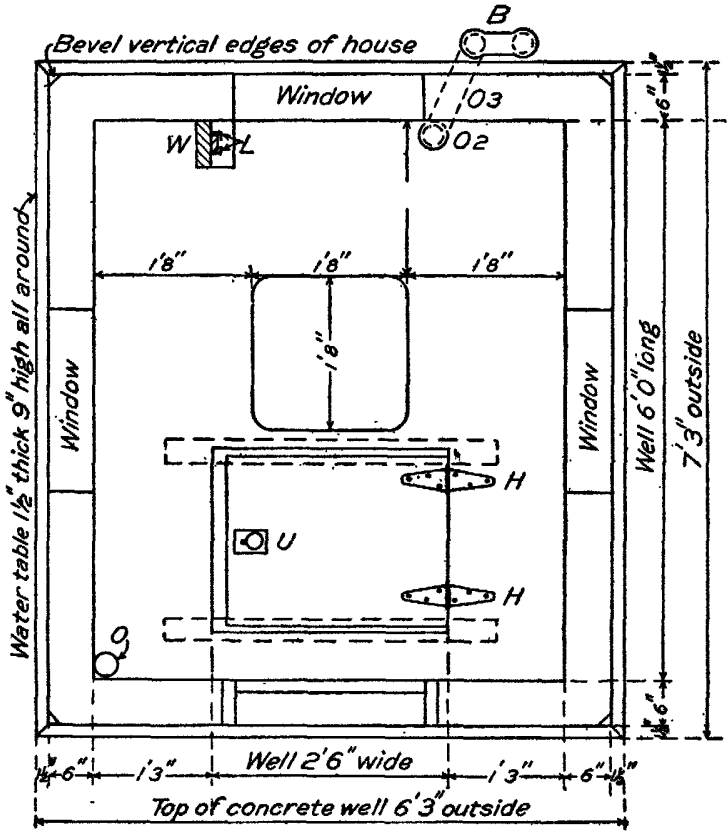

FLOOR PLAN

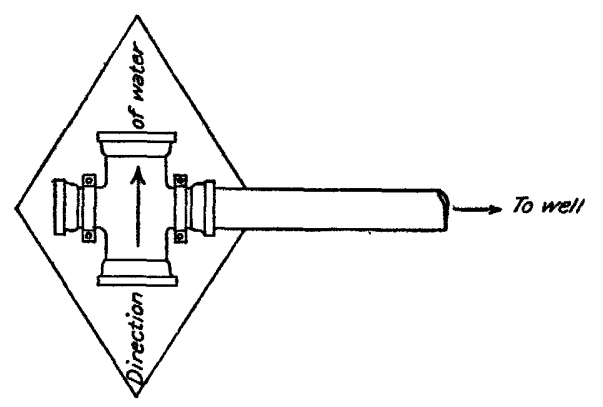

PLANS OF PLAIN-CONCRETE HOUSE AND WELL; SECTIONS AND DETAILS OF INTAKE ANCHORAGE. 
U. 8. GEDLOCACALL SUNVEY
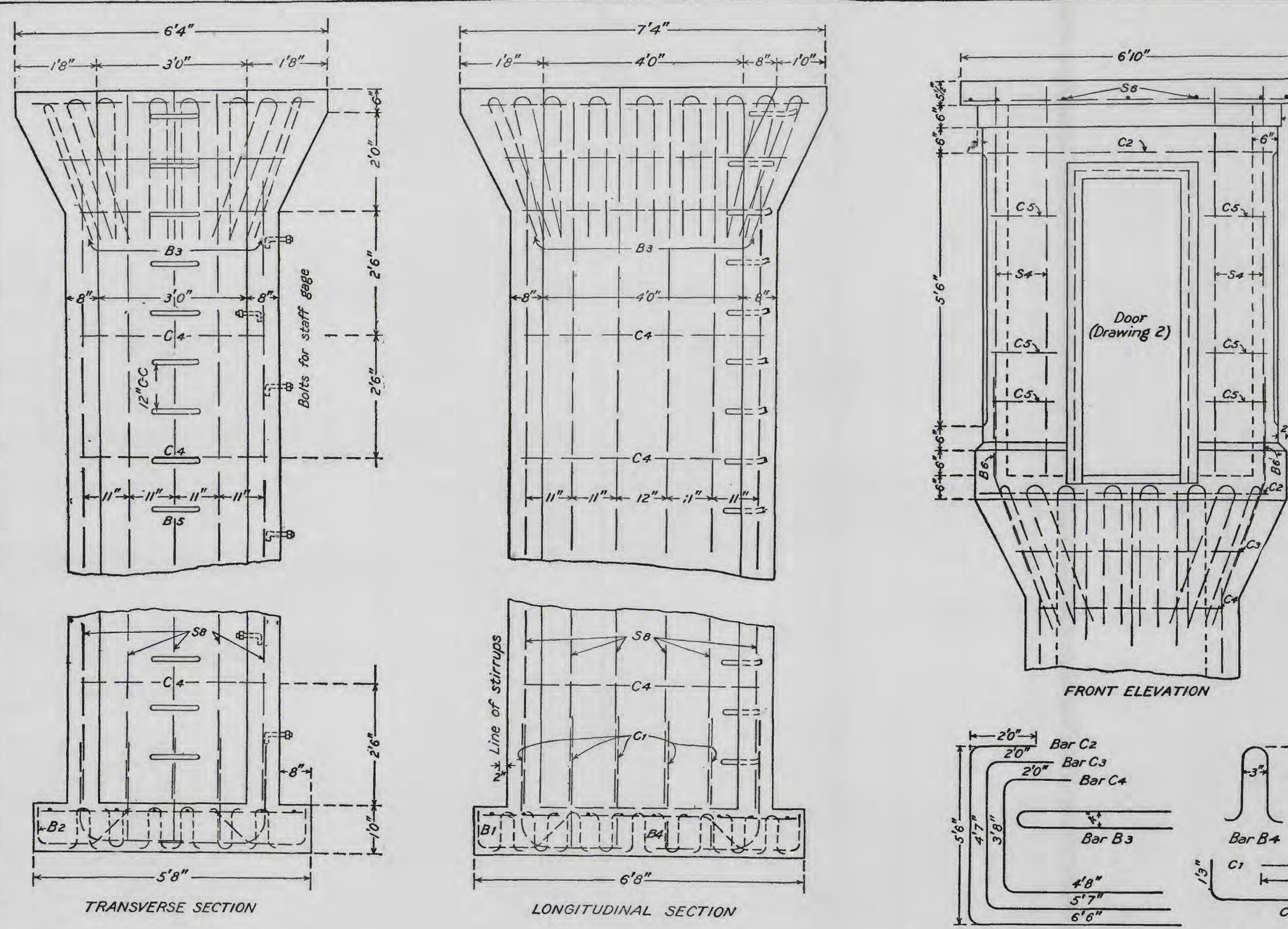

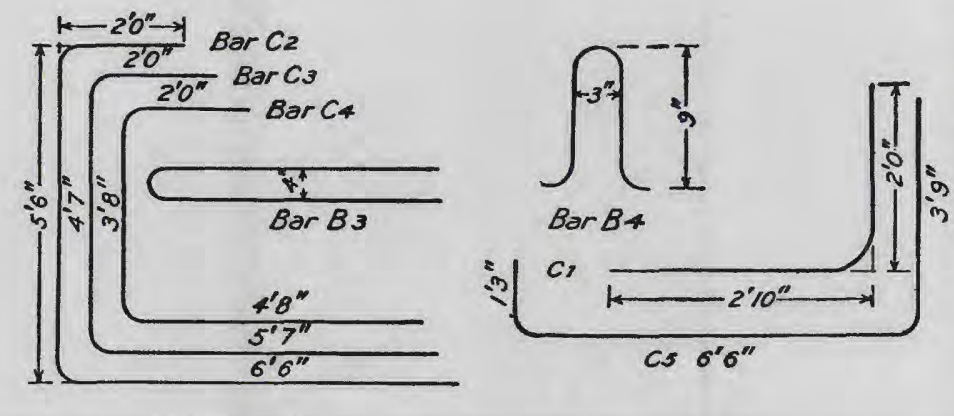

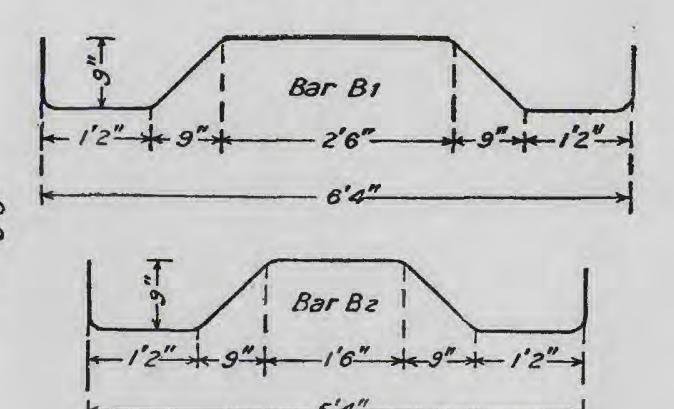
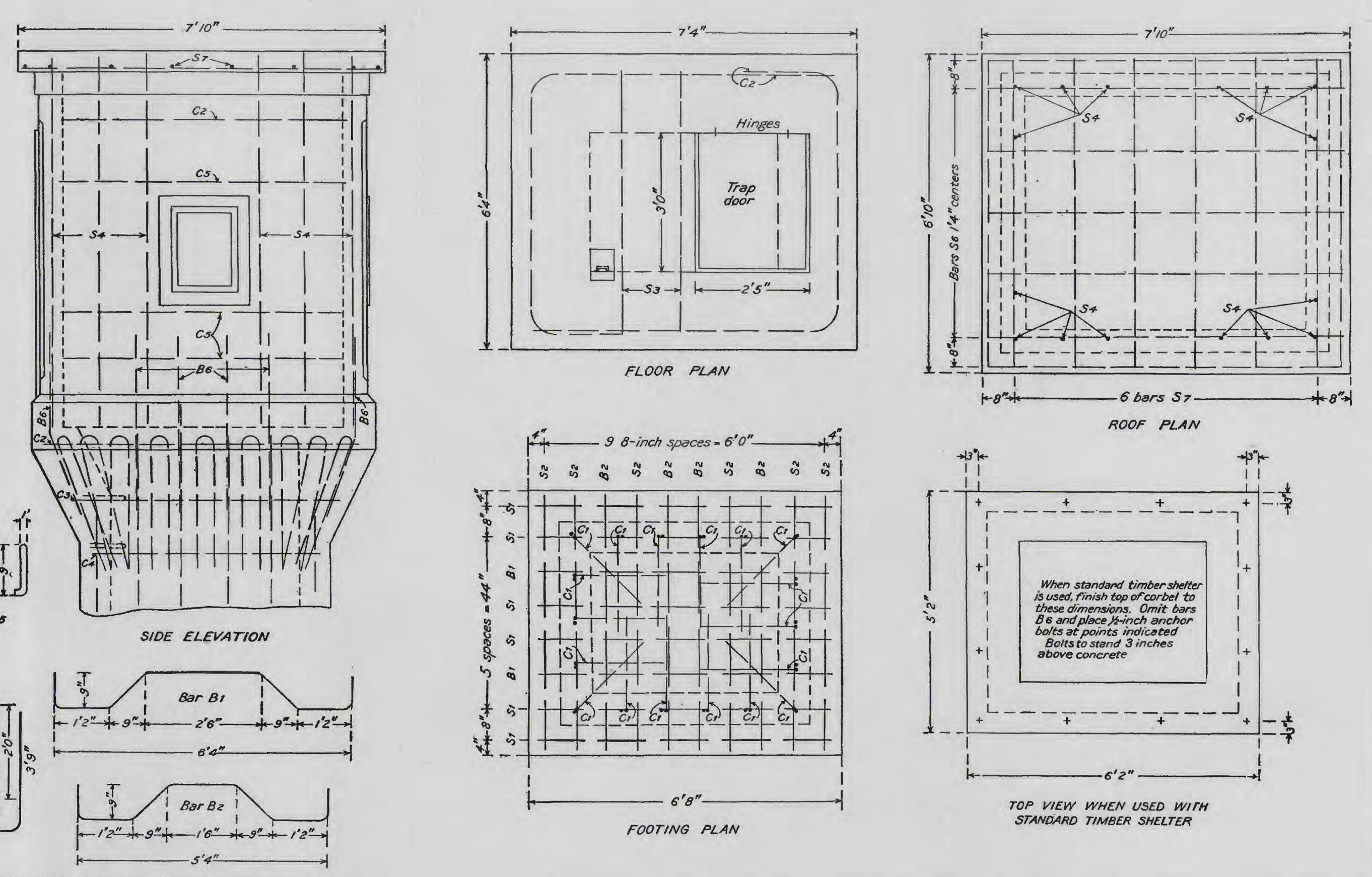
Item 2. 0.6 cubic yard (approximately) of 1-2-4 concrete in walls of well for each foot of depth below the first 3 feet. Each cubic yard requires-

6.4 bags cement.

0.45 yard sand.

0.90 yard stone.

3. 1.2 cubic yards 1-3-6 concrete in footing, requiring-

6 bags cement.

$5 \frac{2}{3}$ yards sand.

$11 \frac{1}{3}$ yards stone.

4. - square feet of wire reinforcement for reinforcing floor.

5. Two pieces light rail $C$, for door rest, each $3 \frac{1}{2}$ feet long.

6. One lifting ring $U$, for trap door, with screws.

7. One pair 6-inch strap hinges $H$, with 4-inch stove bolts for all holes.

8. —- pieces $R$, 1-inch iron 3 feet long, for steps, inner edge to set 3 inches from face of wall.

9. - - $\frac{1}{2}$-inch bolts $J$ with nuts and washers, to hold bed piece to wall.

10. Twelve anchor bolts $\frac{1}{2}$ by 10 inches, with 1 nit $t$ and 1 washer to fasten shelter to well.

11. One gallon carbolineum for treating gage rod, table, etc.

12. One piece lumber 2 by 6 inches by 14 feet, for trapdoor $T$.

13. One standard hook-gage outfit (Table 1, p. 9).

14. One standard shelter (Table 9, p. 26).

15. One standard gage table (Table 15, p. 38).

Note.-The separate items for the forms may be taken from Table 13 (p. 33).

The reinforced-concrete well shown in plan in Plate IX is suitable for use in exposed situations, such as is illustrated in Plate $\mathrm{X}, A$, where the sides of the well may have to withstand the impact of floating débris. A well of this type may be used also with a standard wooden or metal shelter, in which case the top dimension should be finished as noted on the plan, the necessary anchor bolts being set as indicated.

Under some conditions it may be necessary to provide ventilators for the well, hinges and lifting ring for the trapdoor, intake and valve, a gage table, and a standard hook-gage outfit.

In the construction of the reinforced-concrete well use the items specified in Table 7.

TABLE 7.-Bill of material for reinforced-concrete well with timber or metal shelter.

[Lettered items refer to Plate IX.]

Item 1. Three cubic yards 1-2-4 concrete in corbel and footing.

2. Twenty-four cubic feet of $1-2-4$ concrete per foot of well between bottom of corbel and top of footing.

(The quantity of cement, sand, and stone per yard of concrete is given in item 2 of Table 6, p. 20.)

3. Twelve anchor bolts $\frac{1}{2}$ by 10 inches with one nut and one washer, to fasten shelter to well. (See Pl. IX.)

4. - - $\frac{3}{8}$-inch hook bolts with nuts and one washer each to fasten staff gages to well.

5. One trapdoor of wood or sheet iron.

6. Lifting ring and hinges for trapdoor. (See Table 13, p. 33.) 
Item 7. One standard hook-gage outfit (Table 1, p. 9).

8. Intake and valve. (For items see Table 13, p. 33.)

9. One standard gage table (Table 15, p. 38 ).

10. Carbolineum or other wood preservative for treating gages and gage table.

11. Necessary ventilators.

\section{STEEL REINFORCEMENT.}

Item 1. Curved bars $C l$, in footing.

2. Ties $C 2$ and $C 3$, around corbel.

3. Ties $C 4$, around well.

4. Bent bars $B 1$, in footing.

5. Bent bars $B 2$, in footing.

6. Bent bars $B 3$, in corbel.

7. Bent bars $B 4$, in footing.

8. Bent bars $B 5$, steps in well.

9. Straight bars $S 1$ and $S 2$, in footing.

10. Straight bars $S 8$, in walls of well.

NotE.-The separate items for the forms may be taken from Table 16 (p. 40).

Neither plain nor reinforced concrete should be used if the waters of the stream are polluted by mining or industrial wastes that would cause it to disintegrate. It is highly essential that the sand and gravel entering into the concrete be clean.

CONCRETE COMBINATION WELL AND SHELTER.

A concrete well adapted to use on streams characterized by low banks and fluctuating little in stage is shown in Plate $\mathrm{X}, B$, and in plan in Plate XI. In the upper part of the well, which is carried above the surface of the ground about 3 feet, a gage table 12 inches wide is placed. This table is supported at each end by a 2 by 4 inch batten, to which it is securely fastened. The batten should be bolted to the wall of the well. The opening in front of the gage table is covered by a trapdoor $C$, which serves as an extension to the table, useful in the adjustment of the gage. The cover of the well is made of No. 10 steel plate, so arranged that it may be lifted clear of the well, and is prevented from sliding by two battens $S$, of 2 by 4 inch material riveted to its underside. Two hasps $H$, also riveted to the cover in position to engage corresponding staples placed in the concrete, afford a means of locking on the cover. This construction is fire and bullet proof-an important consideration at some stations. In this type of construction ample ventilation must be provided.

TABLE 8.-Bill of material for combination concrete well and shelter.

[Lettered items refer to Plate XI.]

Item 1 . One piece lumber 2 by 4 inches by 14 feet, from which cat-

Two pieces $S$, cleats, 3 feet 6 inches long.

Two pieces $D$, sills, 3 feet 6 inches long.

2. Two pieces 1 by 6 inches by 12 feet, T. G. \& S., from which make shelf $B$ and trapdoor $C$. 


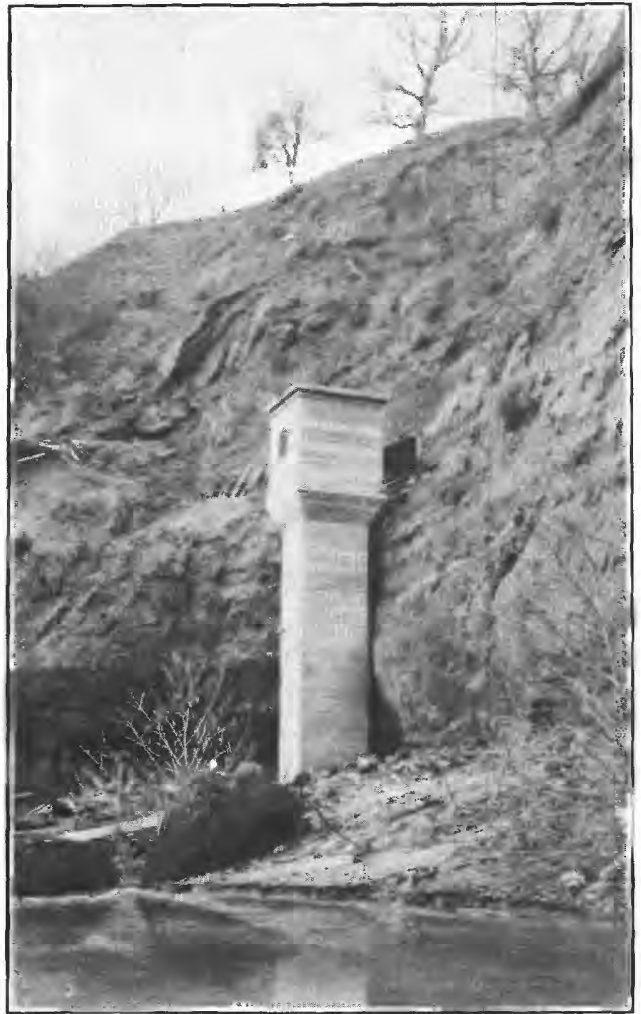

A. REINFORCED-CONCRETE WELL AND SHELTER.

American River at Fairoaks, Cal.

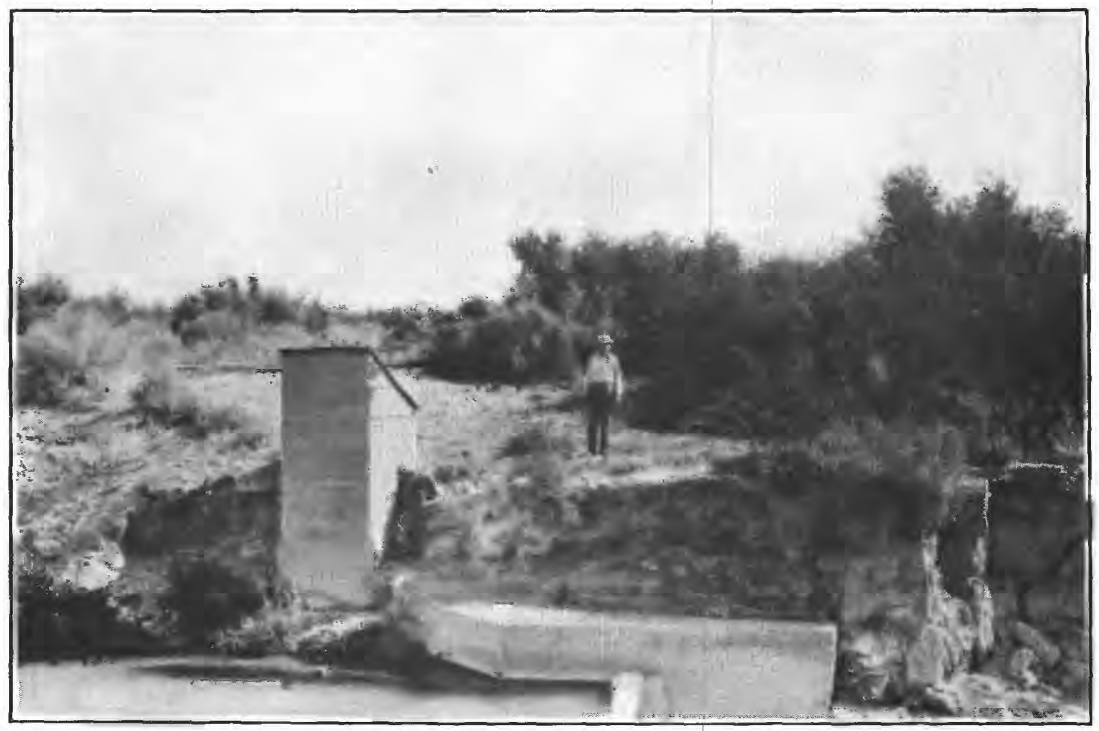

B. CONCRETE WELL AND SHELTER COMBINED.

Muddy River at Moapa, Nev. 

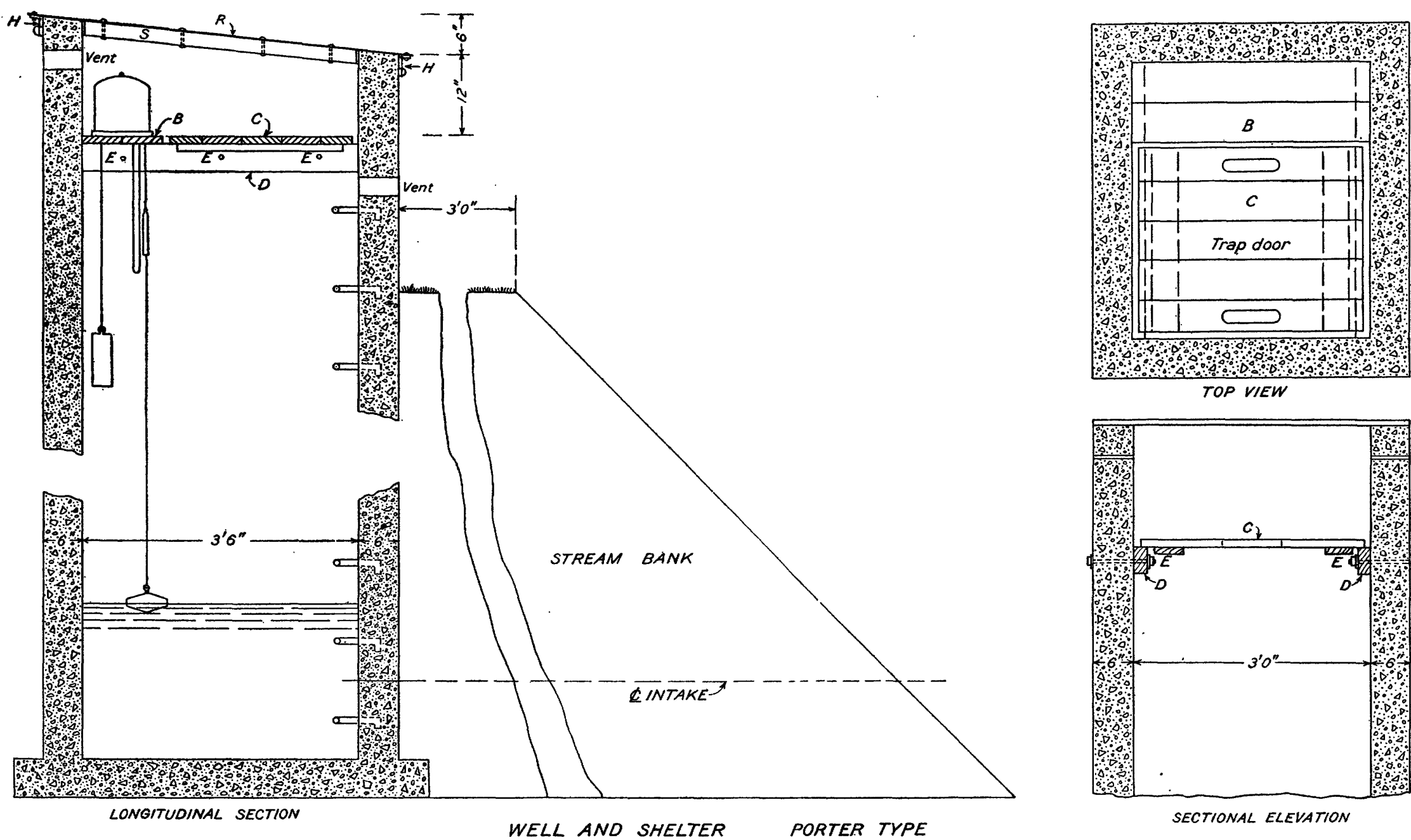

SECTIONAL ELEVATION

PLANS OF COMBINATION CONCRETE WELL AND SHELTER,

Bill of material given in Table 8, page 22. 
Item 3. Six machine bolts $E, \frac{1}{2}$ by 8 inches, with nuts and 2 washers each.

4. Two hasps $H$, riveted to iron cover and 2 staples with shield to go into concrete wall.

5. Two United States Geological Survey standard padlocks.

6. __ pieces 1-inch iron 3 feet long for steps, inner edge to be 3 inches from face of wall.

- 7. One piece No. 10 steel plate $R$, cover, 4 feet 2 inches by 4 feet 8 inches, with cleats $S$ riveted to it.

8. Three dozen F. H. wood screws, 2 inches by No. 10, for shelf and trapdoor.

9. The concrete footing contains 14 cubic feet of concrete.

10. The concrete walls contain 7.5 cubic feet per foot depth of well.

11. One or more intake pipes.

12. Standard hook-gage outfit (Table 1, p. 9).

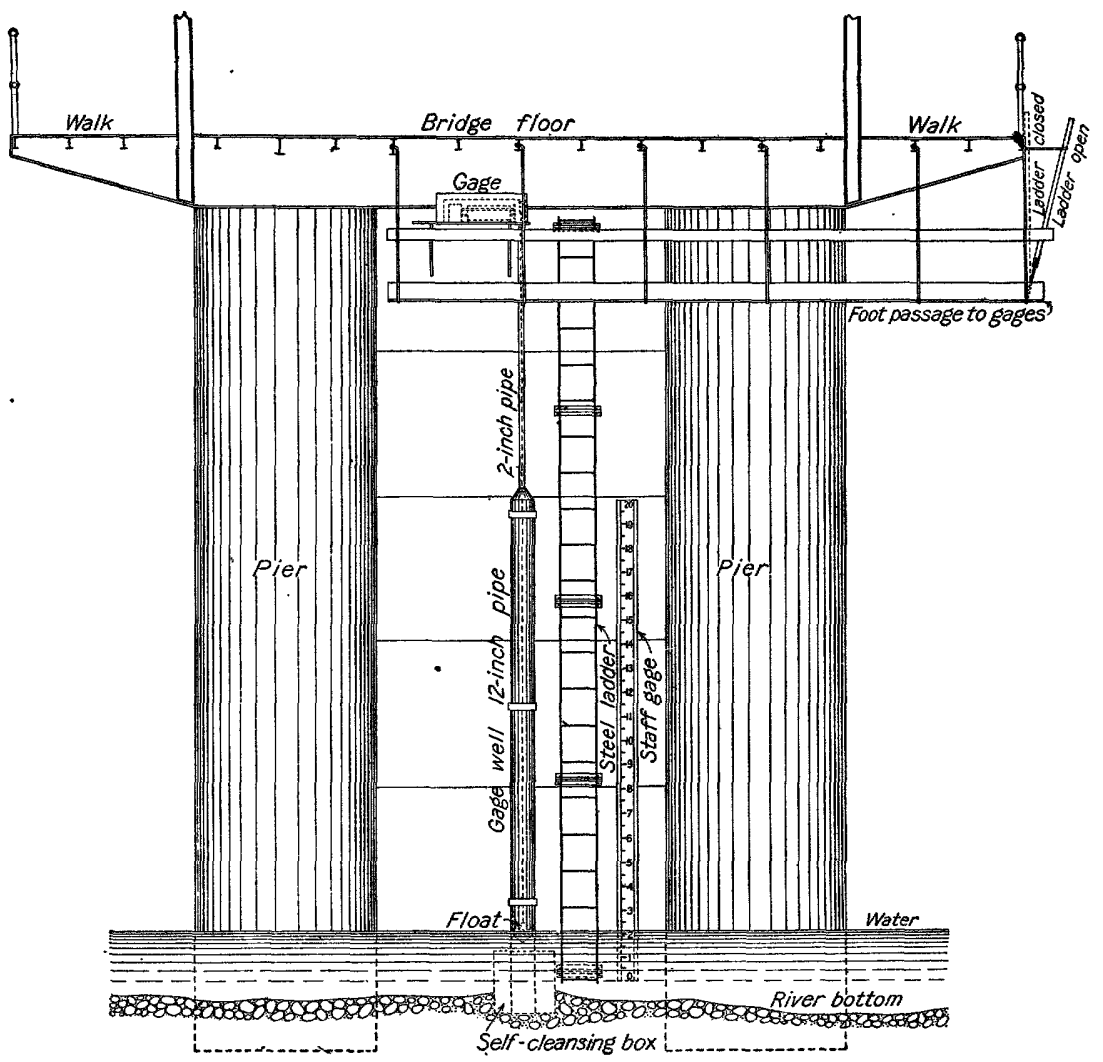

FIgURE 7.-Automatic gage on Cushing bridge piers.

MISCELLANEOUS DESIGNS.

The use of wells of standard design, described and illustrated in the preceding pages, is as a rule desirable, but a number of other types have been designed to take advantage of local conditions. Among these types is the well shown in Plate XII, $A$, and figure 7. This well is made of spiral riveted pipe fastened by steel straps to the web that joins two Cushing cylinders of a bridge pier. From the 
top of the well, which is above extreme high water, a smaller protecting tube for the float tape extends to the hanging platform on which the gage is placed. In installing work of this kind a chain drill is almost a necessity.

In some places cast concrete rings or pipe sections (Pl. XII, $B$ ), corrugated iron pipe (Pl. XVII, $B$, p. 31), and wood-stave pipe have been used for wells.

\section{PROTECTION FROM FREEZITG.}

In northern latitudes special precaution must be exercised to guard against the possible interruption of the record by freezing of the water in the well. In selecting one of the several methods avail-

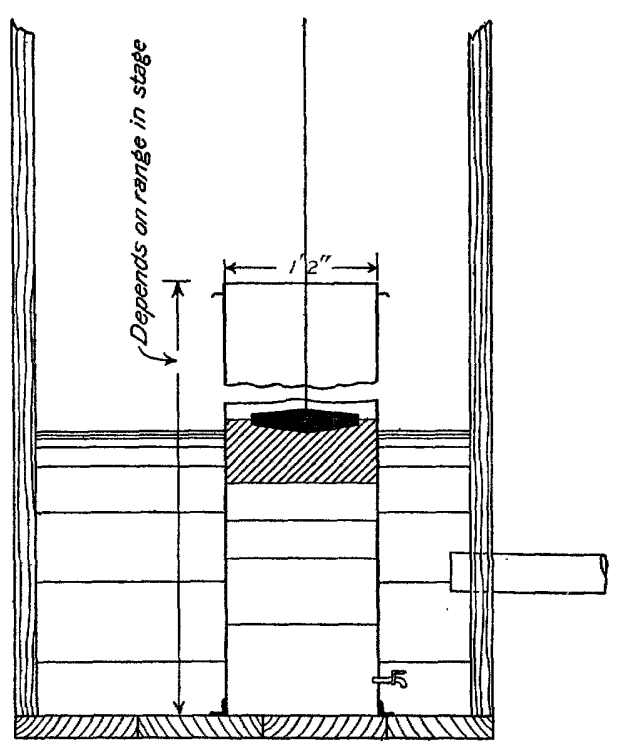

Figure 8.-Oil pipe for float, to prevent freezing.

able to prevent freezing, first cost and probable cost of operation must be considered. The most effective protection against freezing is obtained by placing the well back in the bank and so building the well box that the water surface in the well is at least. 2 feet below the frost line. This method is usually expensive. Where such construction does not seem advisable freezing may be prevented by applying an oil cover, using oil to a depth equal to the probable maximum thickness of ice, plus 2 feet. A device for reducing the quantity of oil required is shown in figure 8. An exposed well may be protected from freezing by building a jacket around it 8 feet above the water surface, leaving between the well box and the jacket a space of 2 feet, which is filled with manure, leaves, or some similar material. Where no other method seems feasible the well may be heated. At stations near a suitable electric circuit a 100-watt carbon light may be burned continuously in the well. An oil heater that may be used for heating the well is prepared by soldering near the top of a 14-quart iron kettle a circular tin plate into which is also soldered a lamp burner, on which a tin or mica chimney is used (fig. 9). The oil chamber holds 2 gallons, sufficient for three days' burning. The kettle heater is counterweighted, so that it will rise and fall with the water in the well. In extremely cold weather more than one such heater may be required. 


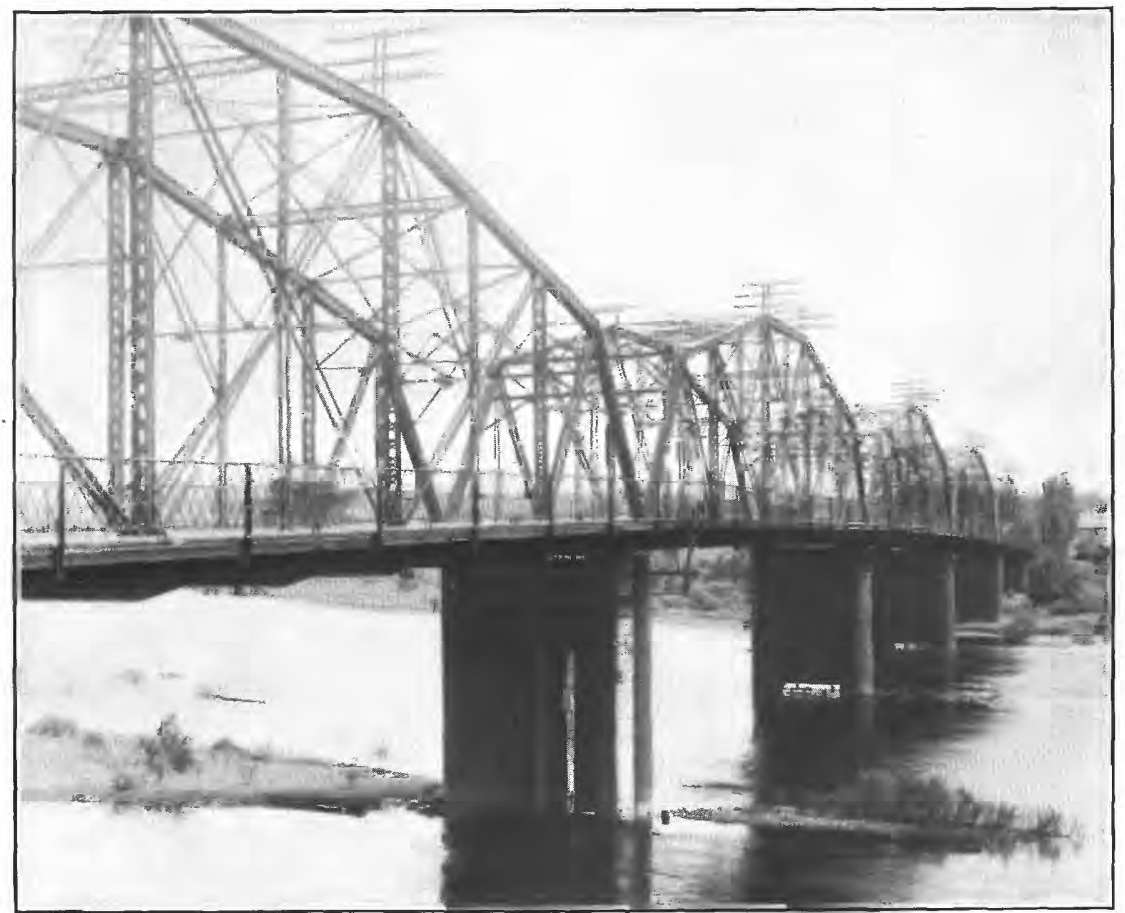

A. GAGES ON WEB OF CUSHING BRIDGE PIERS.

Chippewa River at Chippewa Falls, Wis.

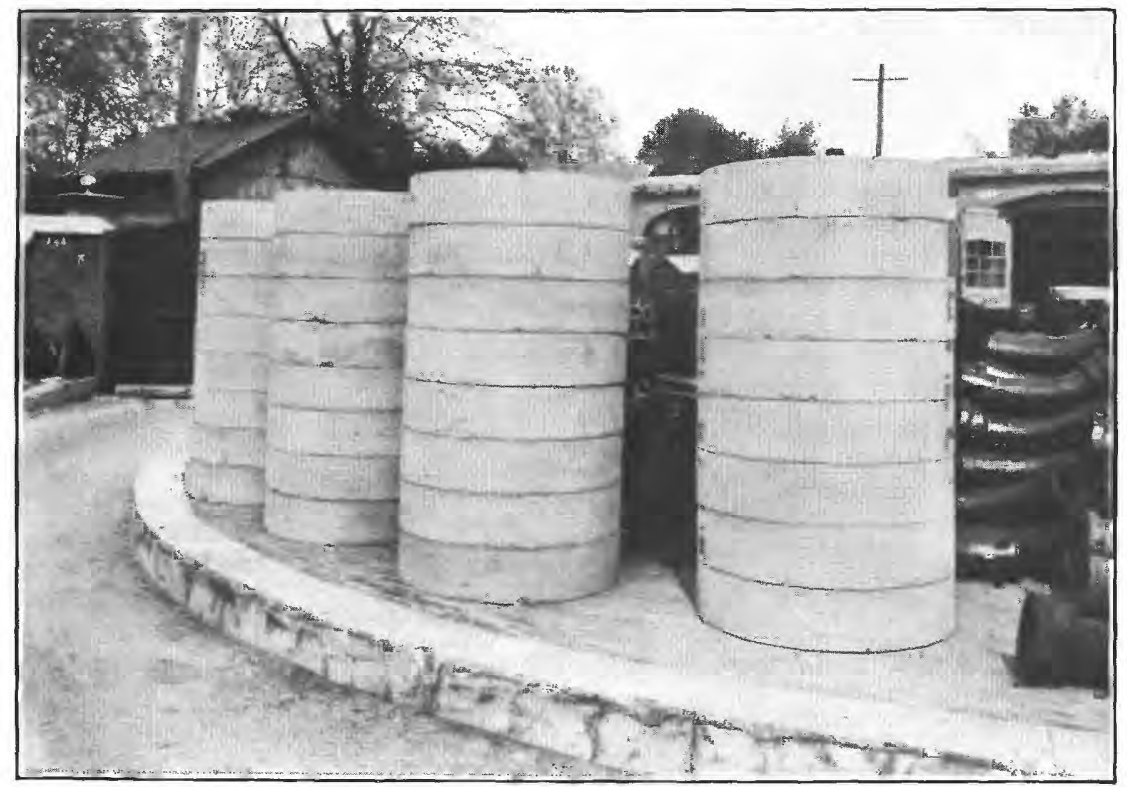

B. CAST CONCRETE RINGS. 
SHELTERS.

TYPES AVAILABLE.

The type of shelter to be used at any station is determined by considering the three elements-utility, safety, and appearancethe weight given to each varying with the location of the station. The types of shelters here illustrated and described are adapted to a wide variety of conditions, and each has proved satisfactory in its own field.

If a station is to be operated all year round the shelter must be large enough to allow the observer to go inside during inclement weather and to pass conveniently around the gage table while inspecting and adjusting the gage. Such shelters are shown in Plates IX (p. 20), XIII (p. 26), and XIX (p. 34).

In the arid regions, where rain is not likely to interfere with the inspection and adjustment of the gage, especially at stations operated during warm weather only, shelters of the types shown in Plates $\mathrm{XV}$ and XVI, $B$ (pp. 28, 30) have proved satisfactory. These shelters may be used on any of the standard wells. The combination shelter and. well shown in Plate XIV (p. 28) should be used only on shallow wells (Pl. VII, $B$, p. 18).

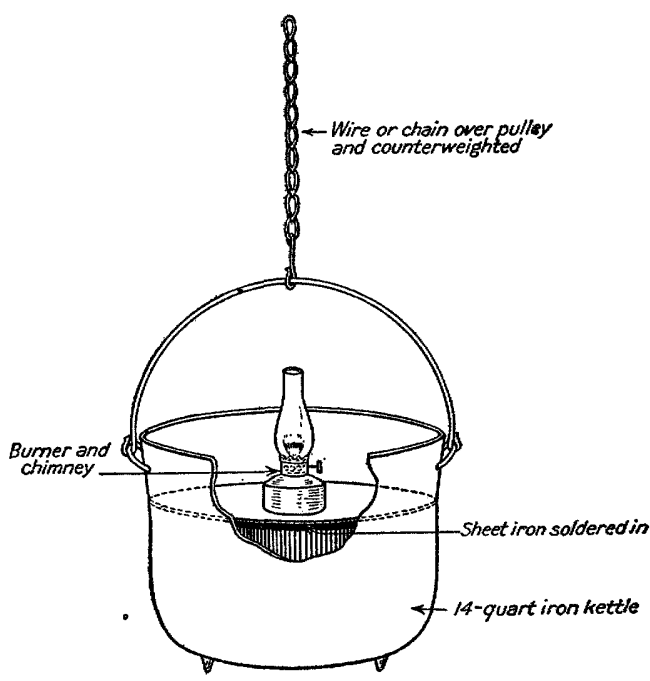

Figure 9.-Floating oil heater, to prevent freezing.

\section{SECTIONAL WOODEN SHELTERS.}

The shelter shown in Plate XIII and Plate XVI, $A$, is built in five sections, one roof section and four side sections, not too large to be carried on a wagon. The siding may be of car-siding, of tongued-andgrooved or of ship-lap lumber, with or without clapboards or shingles. If additional protection is required, the interior may be ceiled. The corner posts $A$ and $B$, the sills $C$ and $D$, and the plates $P 2$, together with the other posts and braces, are cut and spiked together, as shown in detail on the drawing. The siding is nailed to the separate frames, which are then bolted together, as indicated. The roof boards are nailed to the rafters in the proper position and are covered with roofing paper. The roof is then lifted into place and bolted to the side walls. The shelter is bolted to the top of the well, as shown in 
Plate XIII or Plate XXIV, $B$ (p. 40). Windows may be placed, one on each side and one in the rear of the building. Stock sashes with six lights of 8 by 10 inch glass are placed on the frames $E$ and are held in place by cupboard buttons, screwed to the frames $J$. The sashes are flush with the inside faces of the frames $E$ and $J$. Each window is protected by a wooden shutter, which is fastened on the inside by a screw hook and eye. A door, provided with hasp, staple, and lock, should be made to suit the style of shelter. For a wooden shelter ceiled inside and with siding outside, a standard door and frame, as shown on the plans for concrete shelter, may be used.

The floor should be of 2 -inch plank securely spiked to the sills. In constructing the trapdoor through which entrance is had to the well, ample allowance should be made for swelling, say an inch each side and at the end. The bed piece for the hook gage should be fastened to the frame of the well and to a horizontal piece of 2 by 6 inch material 5 feet long, fastened to the top of the frames $E$. To the bed piece standard lugs should be attached on each side of the hook-gage rod, spaced about 3 feet apart. Opposite the standard scale a sash latch should be provided to hold the gage at any desired position.

Where the change of stage is considerable it may be necessary to allow the hook gage to pass through the roof by using a small trapdoor or the same device as for concrete shelters.

The shelters should be kept well painted or should be treated with carbolineum. A bill of material and cutting scheme for timber shelters is given in Table 9.

TABLE 9.-Bill of material for standard wooden shelter.

[Lettered items refer to Plate XIII.] .

LUMBER.

Item 1. Four pieces 2 by 4 inches by 12 feet ( 32 feet b. m.), S $4 \mathrm{~S}$, from which cut-

Two pieces $A 2$, posts, 5 feet 10 inches long.

Two pieces $B 2$, posts, 5 feet 10 inches long.

Two pieces $C$, sills, 5 feet 4 inches long.

One piece $M$, lintel, 2 feet 6 inches long.

Four pieces $P 1$, braces, 1 foot long.

One piece $R 5$, rafter, 2 by 3 inches by 5 feet long.

2. Twelve pieces 2 by 4 inches by 10 feet ( 80 feet b. m.), S $4 \mathrm{~S}$, from which cut-

Two pieces $A 1$, sills, 7 feet long.

Two pieces $B 1$, sills, 7 feet long.

Two pieces $D$, sills, 5 feet long.

Four pieces $E$, sills, 5 feet long.

Two pieces $G$, door jambs, 7 feet long.

Six pieces $J$, window jambs, 2 feet 4 inches long.

Two pieces $P$, sills, 4 feet 8 inches long.

Two pieces $P 2$, plates, 5 feet long.

Two pieces $R 3$, rafters, 5 feet long. 


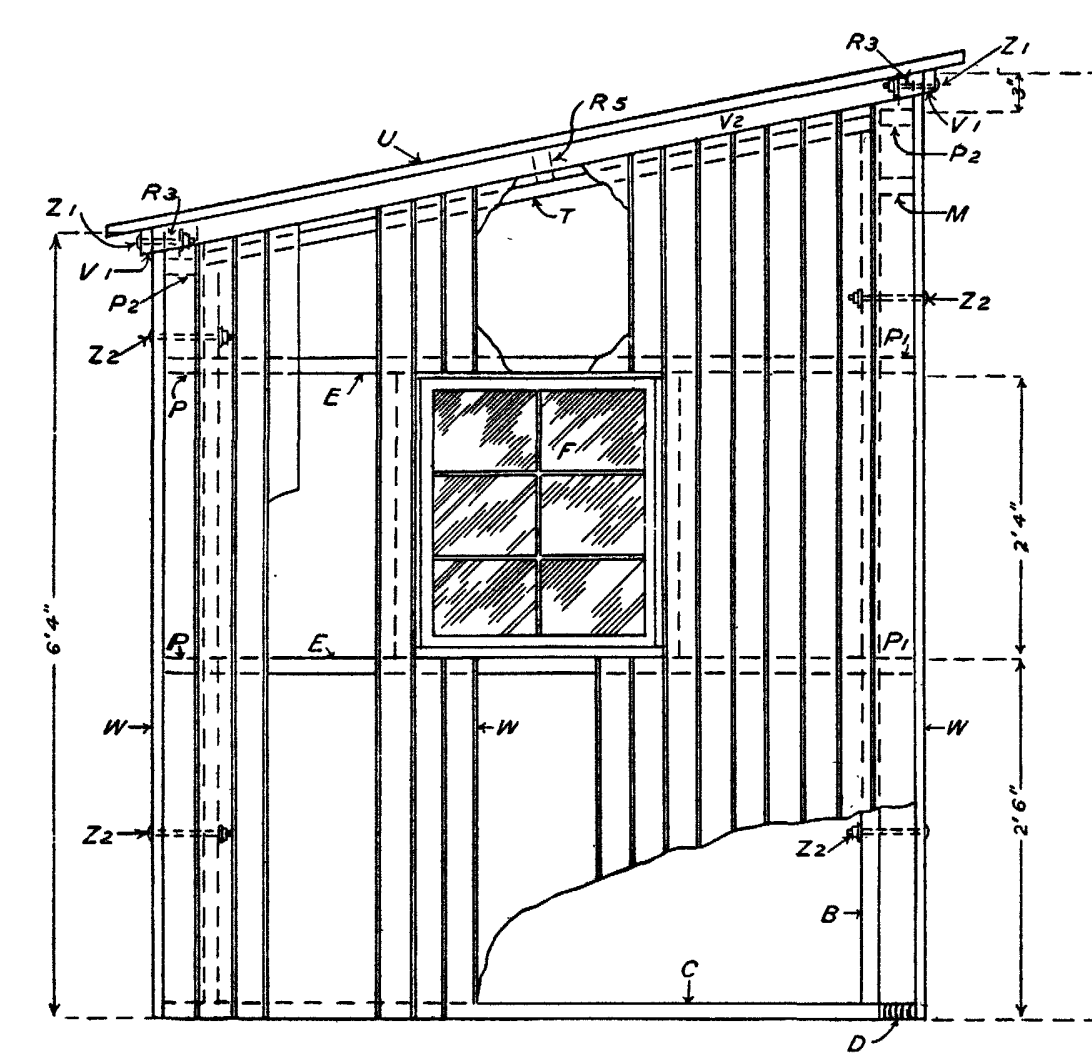

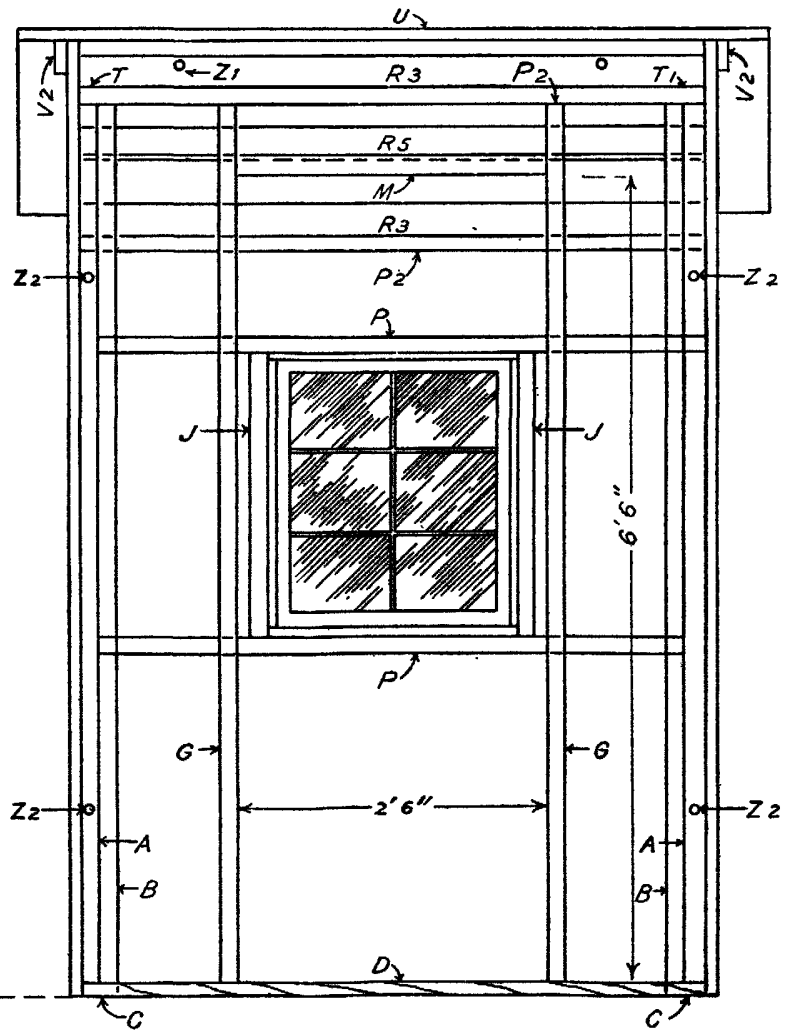

FRONT AND REAR

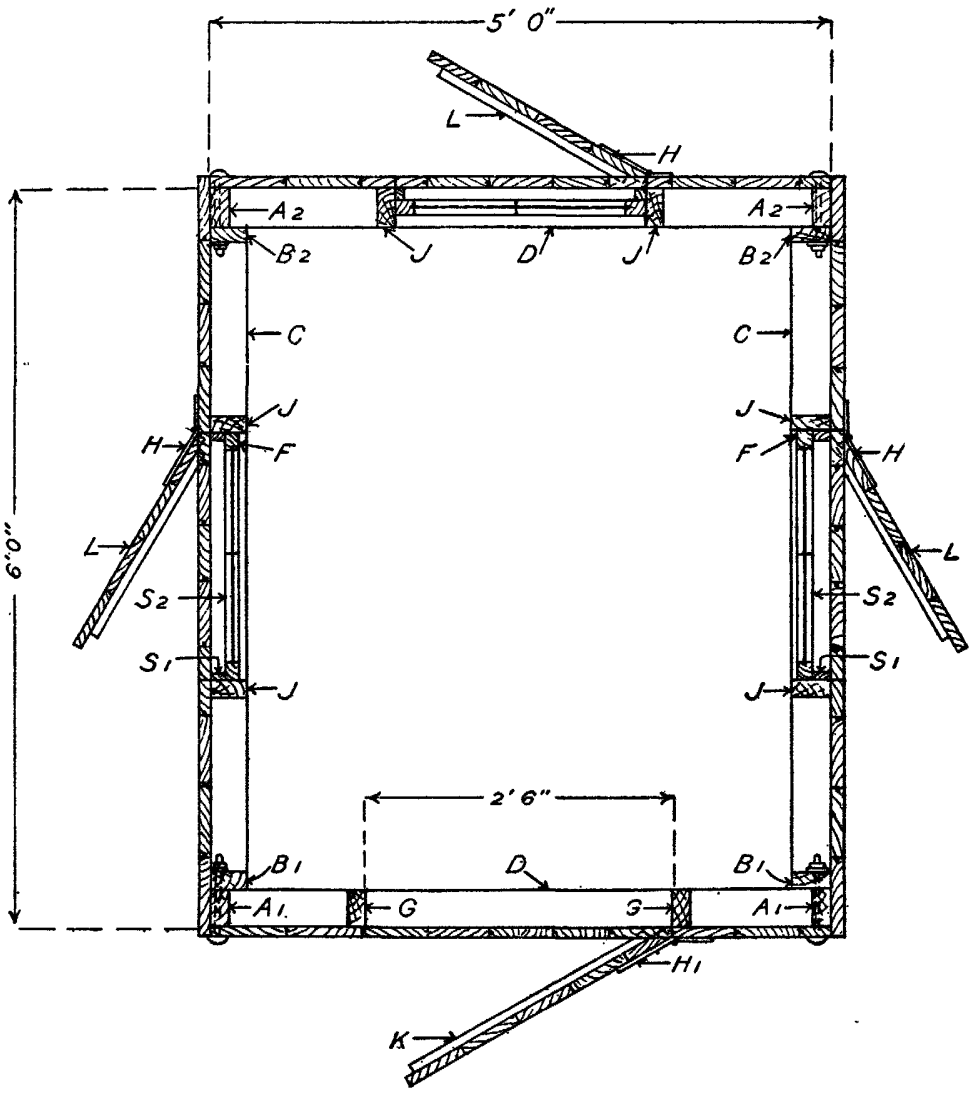

S.ECTIONAL PLAN

PLANS OF STANDARD WOODEN SHELTER. 
Item 3 . Four pieces 1 by 4 inches by 12 feet ( 16 feet b. m.), S $4 \mathrm{~S}$, from which cutTwo pieces $V 1$, battens, 5 feet 2 inches long.

Two pieces $V 2$, battens, 6 feet 4 inches long.

- battens on window shutters.

4. 1-inch boards for roof to be 7 feet long and sufficient in number to cover 6 feet of width (42 square feet net).

5. Boards on each side to cover 6 feet 2 inches of width and to be of proper height (87 square feet net).

6. Boards on rear 6 feet 4 inches long, to cover a length of 5 feet 0 inches (32 square feet net).

7. Boards on front 7 feet 7 inches long, to cover 5 feet of width-less doorway when stock door is used ( 34 square feet net).

8. Three window sashes $F$, each with 6 lights, 8 by 10 glass.

9. One stock door, 2 feet 6 inches by 6 feet 6 inches, with dead lock and hinges ready to hang.

Note.-The cutting scheme should be followed carefully. It is customary in construction work in the field to make a reasonable increase in bills of lumber to allow for cuts, undersized pieces, and mistakes.

HARD WARE.

Item 10. Three pairs 6-inch $T$ hinges $H$.

11. One pair 10-inch $T$ hinges $H 1$.

12. Six door buttons, 2 inches, to secure window sashes (Sargent \& Co., No. 10).

13. Four carriage bolts $\frac{3}{8}$ by $4 \frac{1}{2}$ inches, $Z 1$, with one washer each.

14. Eight carriage bolts $\frac{3}{8}$ by 7 inches, $Z 2$, with one washer each.

15. One safety hasp with staples and screws.

16. One United States Geological Survey padlock.

17. Five pounds 20d. (4-inch) nails.

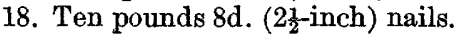

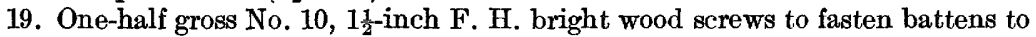
window shutters.

20. Four screw hooks and eyes for window shutters and door.

21. - waterproof roofing to cover 42 square feet net.

22. Four pounds No. 8 large-head barbed roofing nails.

23. Two gallons gray mixed paint.

CAIIFORIIA SHELTER.

This type of wooden shelter (Pl. VII, $B, \mathrm{p} .18$ ) is only large enough to contain the gage. Because of its low cost it is adapted to use on small streams and canals or for temporary purposes. When so used it may be mounted on the special well shown in Plate XIV if the well is shallow. The shelter consists of a base $G$, of 2-inch material, across which is laid a smooth floor, 1 inch thick, of tongued-andgrooved material. The sides $A$ and the back $B$ closely surround this floor and rise above it to the dimensions shown on the drawing. The sides and back are securely nailed to each other and to the floor $F$, as well as to the corner posts and battens $D$ and $E$. The roof $R$ is hinged at the back, and the front is also fastened by hinges to the roof, the shelter being opened as shown on the drawing. The roof of this shelter is ordinarily covered with No. 24-gage galvanized iron. The structure should be kept well painted. A bill of material is given in Table 10. 
TABLE 10.-Bill of material for California-type well and shelter.

[Lettered items refer to Plate XIV.]

LUMBER.

Item 1. Six pieces 1 by 6 inches by 14 feet ( 42 feet b. m.), T. G. \& S., from which cutSix pieces $F$, gage table, 2 feet 2 inches long.

Six pieces $G$, well cover, 3 feet 4 inches long.

One pieee $J$, batten, 1 by 2 inches by 3 feet 2 inches long.

One piece $J 1$, batten, 1 by 2 inches by 3 feet 4 inches long.

Two pieces $L$, battens, 1 by 2 inches by 2 feet 4 inches long.

Two pieces $M$, battens, 1 by 3 inches by 1 foot 4 inches long.

One piece $M 1$, batten, 1 by 3 inches by 3 feet long.

Two pieces $N$, battens, 1 by 3 inches by 2 feet 6 inches long.

Six pieces $R$, roof sheathing, 3 feet 6 inches long.

2. Four pieces 1 by 8 inches by 12 feet ( 32 feet b. m.), T. G. \& S., from which cut-

Six pieces $A$, sides of shelter, 2 feet 4 inches long.

Six pieces $B$, back and front of shelter, 2 feet 8 inches long.

Two pieces $C$, battens, 1 by 4 inches by 1 foot 5 inches long.

Two pieces $E$, corner braces, 1 by 4 inches by 1 foot 8 inches long.

Two pieces $K$, battens, 1 by 4 inches by 1 foot 10 inches long.

Three pieces $S$, door to well, 2 feet 2 inches long.

3. One piece 2 by 4 inches by 2 feet, S $4 \mathrm{~S}$, from which cut 2 pieces $D$, corner braces, 2 by 2 inches by 2 feet long.

4. - - pieces $O$, well frame, 2 by 4 inches by 2 feet long.

5. Two pieces $P 1$, well frame, 2 by 4 inches by 2 feet 6 inches.

6. - pieces $P$, well frame, 2 by 4 inches by 2 feet 4 inches.

7. Two pieces $Q$, door battens, 1 by 4 inches by 1 foot 11 inches.

8. Four pieces $T 1$, side of well, 2 by 6 inches by depth from surface of ground to bottom of well plus 6 inches.

9. Four pieces $T 2$, side of well, 2 by 6 inches by depth from surface of ground to bottom of well plus 3 feet.

10. Twelve pieces $U$, back and front of well, 2 by 6 inches by depth from surface of ground to bottom of well plus 3 feet.

11. Six pieces $V$, bottom of well, 2 by 6 inches by 2 feet 4 inches.

12. - pieces $X$, ladder rounds, 1 by 4 inches by 2 feet.

13. Two pieces $Y$, ladder poles, 2 by 4 inches by depth of well.

14. One piece $Z$, batten, 2 by 4 inches by 2 feet 4 inches $S 4$ S.

\section{HARDWARE.}

Item 15. One pair 3-inch butt hinges $H$, with screws.

16. One pair 5-inch $T$ hinges $H 3$, with screws.

17. One safety hasp, 6 inches, $H 1$, with screws.

18. One safety hasp, 6 inches, $H 2$, with screws.

19. One pair strap hinges, 6 inches, $T$, with screws.

20. Two pounds $4 \frac{1}{2}$-inch wire nails (30d.).

21. Eight pounds 4-inch wire nails (20d.).

22. Five pounds $2 \frac{1}{2}$-inch. wire nails ( $8 \mathrm{~d}$.).

23. Two pounds 2 -inch wire nails ( $6 \mathrm{~d}$.).

24. - gray mixed paint.

25. One sheet No. 24 galvanized iron, 36 inches by 45 inches, to cover roof.

26. Intake pipe, fittings, anchor, etc., as required.

NotE.-This bill of material is based on special well shown in Plate XIV. The cutting scheme shown above should be followed carefully. It is customary in construction work in the field to make a reasonable increase in bills of lumber to allow for cuts, undersized pieces, and mistakes. 


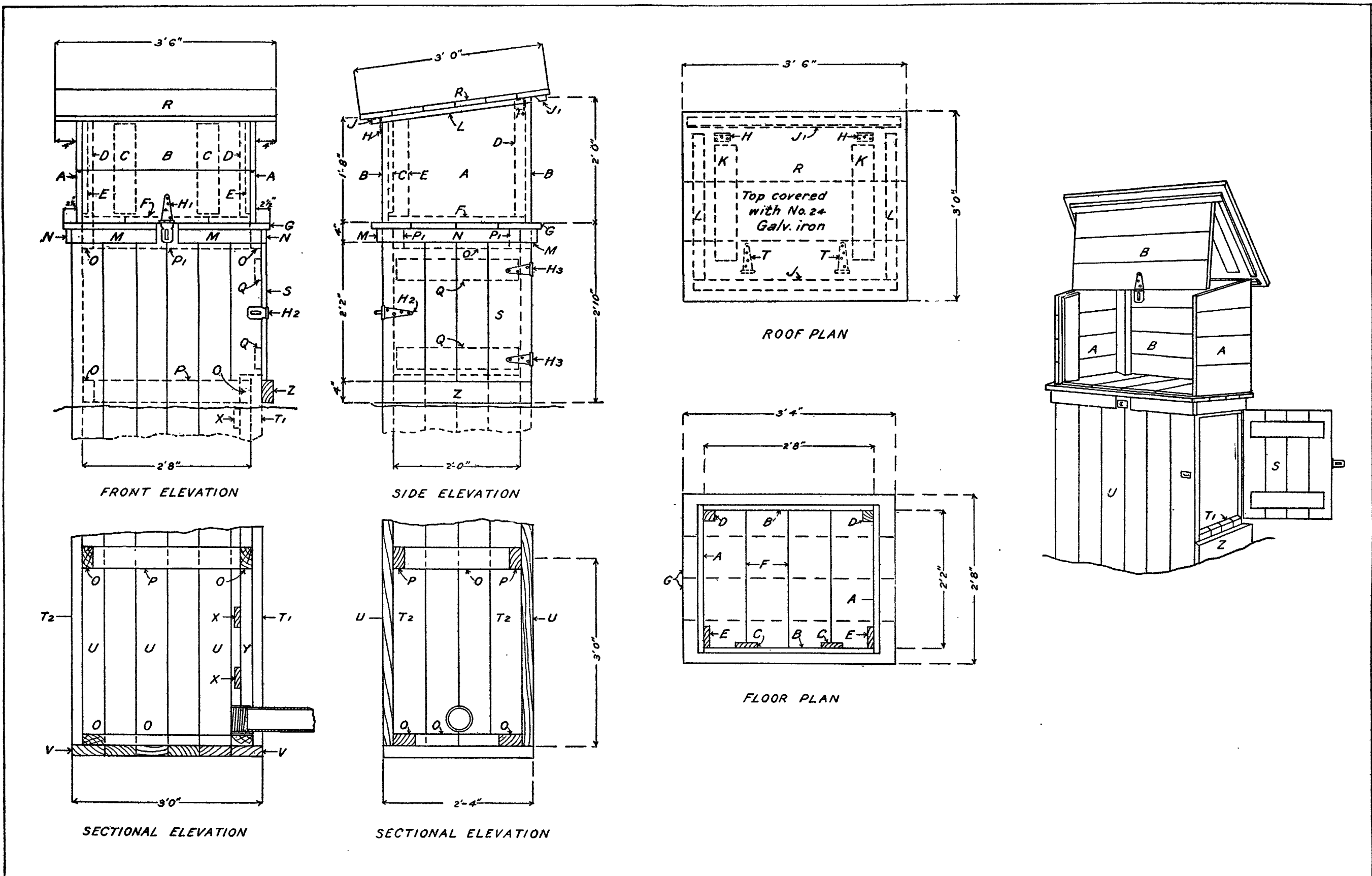




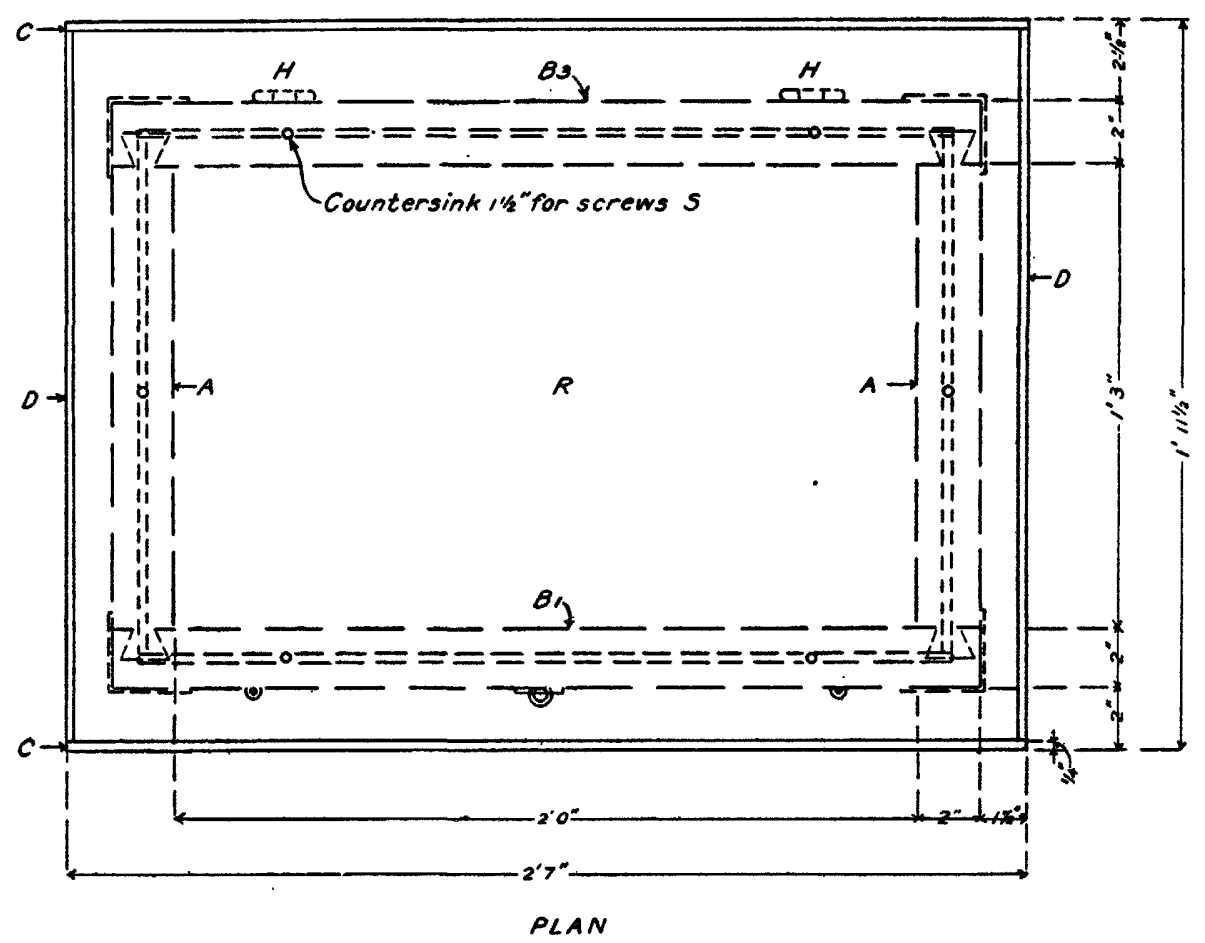

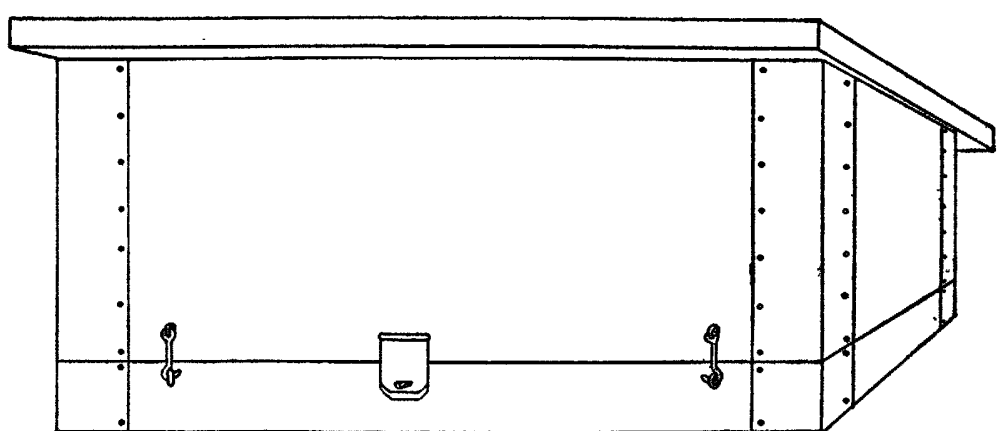

PERSPECTIVE VIEW

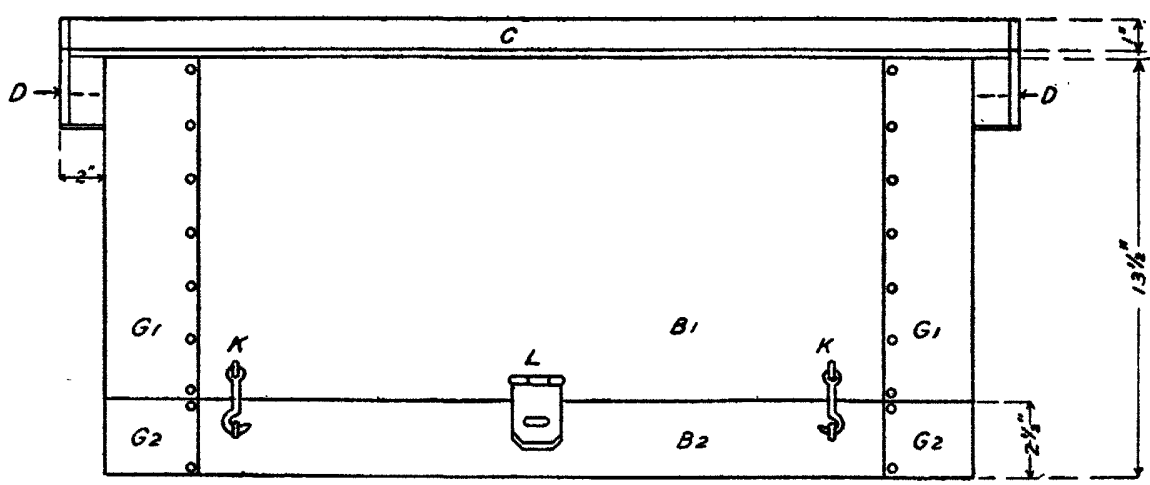

FRONT ELEVATION

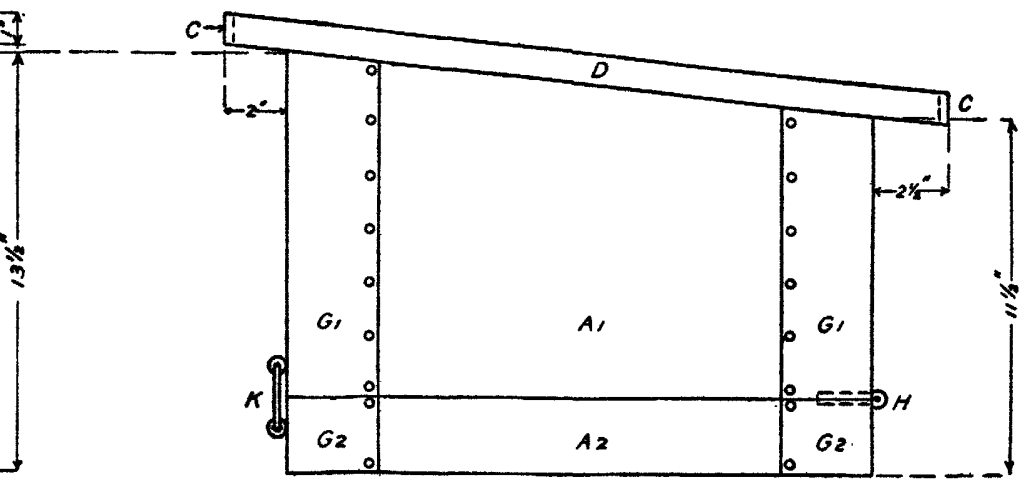

END ELEVATION 
BOX SHELTER.

A very simple and inexpensive shelter is shown in Plate XV. This type has been found useful in the arid regions in situations similar to those shown in Plate V, $B$ (p. 15).

The shelter is made of 2-inch material, the sides $A$ being dovetailed into the back and front $B$, the corners being bound with galvanized sheet iron and the top covered with the same material or roofing paper. The box is separated by a tongued-and-grooved joint into upper and lower parts, the tongue being on the pieces $A 2-B 2$, and the groove being on the upper part. The lower part, or base, is fastened to the top covering of the well by $2 \frac{1}{2}$-inch screws, countersunk into the pieces $A 2-B 2$. Hinges $H$ allow the cover to be turned back when inspecting the gage. If a gage of unusual dimensions is used, care must be taken to adjust the size of the box accordingly.

These shelters are made to best advantage in a woodworking mill. The parts may be crated and shipped into the field to be nailed together. They should be painted before being shipped. A bill of material is given in Table 11.

TaBLE 11.-Bill of material for box-type shelter.

[Lettered items refer to Plate XV.]

LUMBER.

Item 1. One piece 1 by 6 inches by 14 feet ( 7 feet b. m.), T. G. \& S., from which cut 6 roof boards $R, 1$ foot 11 inches long.

2. Two pieces 2 by 6 inches by 10 feet ( 20 feet b. m.), T. G. \& S., from which cut-

Four pieces $A 1$, ends, 1 foot 5 inches long.

Two pieces $A 2$, ends, 2 by 3 inches by 1 foot 5 inches long.

Two pieces $B 1$, front, 2 feet 4 inches long.

Two pieces $B 3$, back, 2 feet 4 inches long.

Two pieces $B 2$, front and back, 2 feet 4 inches long.

3 . Three pieces lath, $C$ and $D$, for binding edge of roofing.

4. Covering for roof. May be tar paper or No. 24 galvanized iron 24 by 36 inches.

HARDWARE.

Item 5. One piece No. 27 galvanized sheet iron, 30 inches wide by 11 inches long, from which cut--

Two pieces $G 1,6$ inches wide by 11 inches long.

Two pieces G3, 6 inches wide by $9 \frac{1}{2}$ inches long.

Four pieces $G 2,2 \frac{1}{2}$ inches wide by 6 inches long.

6. One pair 3-inch butt hinges $H$, with screws.

7. One safety hasp $L, 6$ inches, with screws.

8. One United States Geological Survey standard padlock.

9. Two screw hooks and eyes $K$.

10. Six wood screws, F. H., bright, $S$, fastening shelter to deck over well.

11. Two pounds $20 \mathrm{~d}$. (4-inch) wire nails.

12. One pound $1 \frac{1}{2}$-inch No. 6 gage wire nails to fasten corner plates.

13. One quart gray mixed paint.

Note.-The items above do not include the deck over the well. 
PORTABLE SHELTER.

A shelter that has been found useful in preliminary studies with automatic gages is shown in Plate XVII, $A$.

The.structure shown in plan in Plate XVIII consists of four standards of $\frac{3}{4}$-inch galvanized pipe, which are driven into the bed of the stream at a favorable site and to which is clamped the deck $D$. For convenience in transportation the pipe is cut into 2-foot sections, which are joined in the field by pipe couplings. The threads on the pipe should be cut long enough to permit the ends of the pipe to touch within the couplings when screwed up. A cap is placed on the top section to serve as a drivehead when the pipe is driven in. Wire loops are slipped over the pipe standards to prevent them from spreading as they are driven. After the pipes have been driven far enough into the stream bed to hold firmly, the deck is fitted on the standards, is made level, and is clamped in place. Hexagon nuts on the bolts and an $S$ wrench add to the ease with which the deck may be set. The holes in the clamps $C$ may advantageously be slotted. The slots should be 1 inch long to allow for adjustment.

The deck having been fastened in place, the galvanized side plates are next put on. These plates are cut from a stock sheet 36 inches wide and 96 inches long. The positions of all the holes should be carefully laid out on one plate, which is then drilled with holes just large enough to admit the end of the center punch. This plate is then retained as a templet, from which all other side plates are duplicated. The side plates are kept from bending by wooden stiffeners, $\frac{1}{2}$ by 1 inch in cross section and 18 inches long, with round-head stove bolts, $\frac{1}{4}$ by 1 inch, with a washer under the head and next the wood.

The side plates are joined together and fastened to the standards by stove bolts, $\frac{3}{16}$ inch by 4 inches, which may be bent readily in a vise, around a short piece of $\frac{3}{4}$-inch pipe. The heads of the bolts are sawed off and the ends threaded with a die (thread 10 by 24) held in a clamp that can be used in a bit stock.

For convenience in shipment the side plates, stripped of stiffeners, are placed between the sills $E$; and the deck, with plates, bolts, and all tools, are packed in the canvas cover. The pieces of pipe are tied together and shipped as a separate parcel.

Stove bolts, wing nuts, and washers should be bought by the box and prepared for use by the engineer before he goes into the field: 


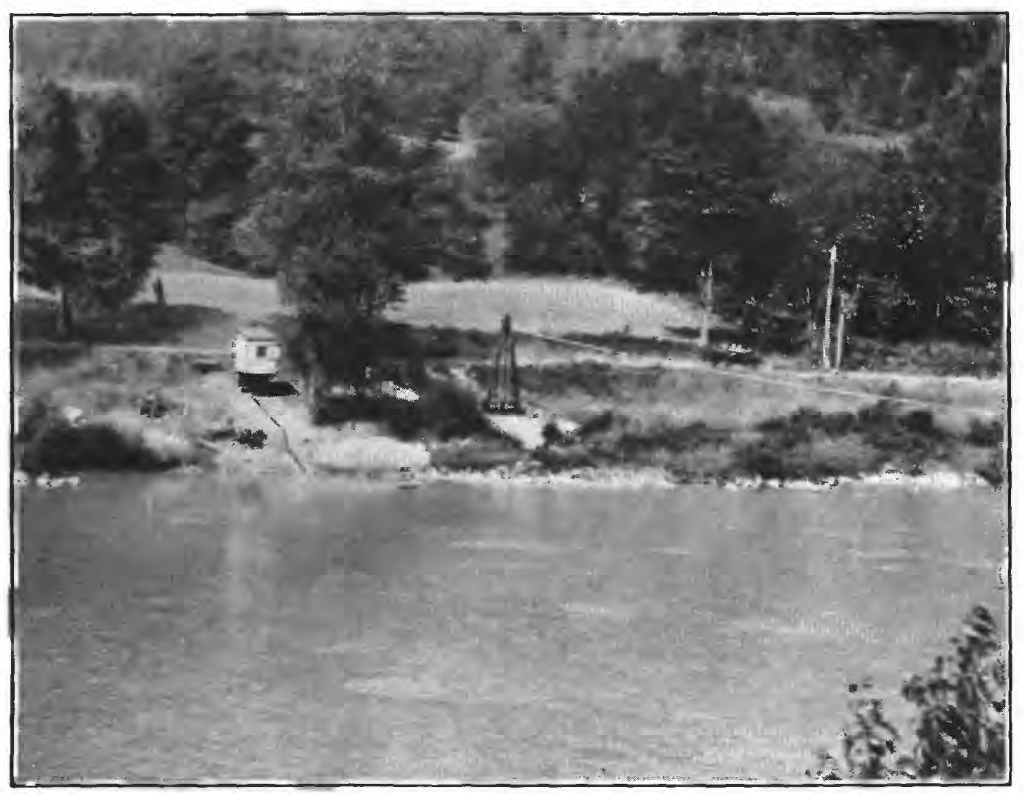

A. STANDARD WOODEN SHELTER.

Deerfield River at Charlemont, Mass.

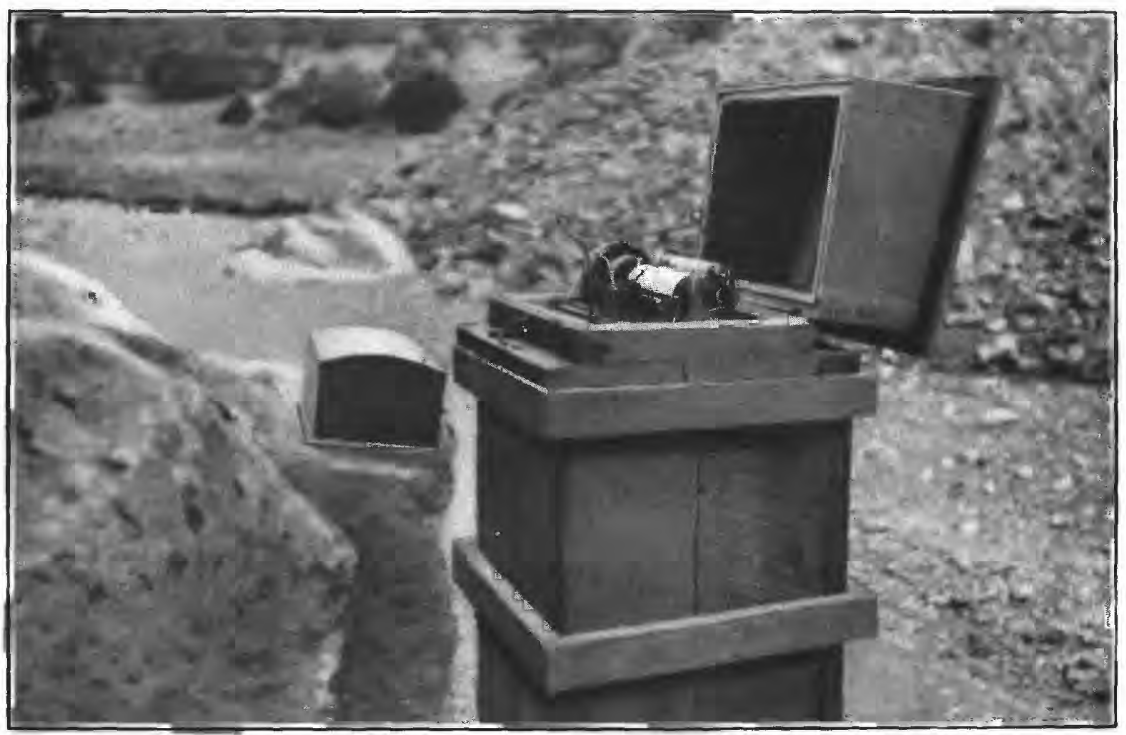

B. WOODEN-BOX SHELTER.

Arroyo Hondo at Santa Fe, N. Mex. 


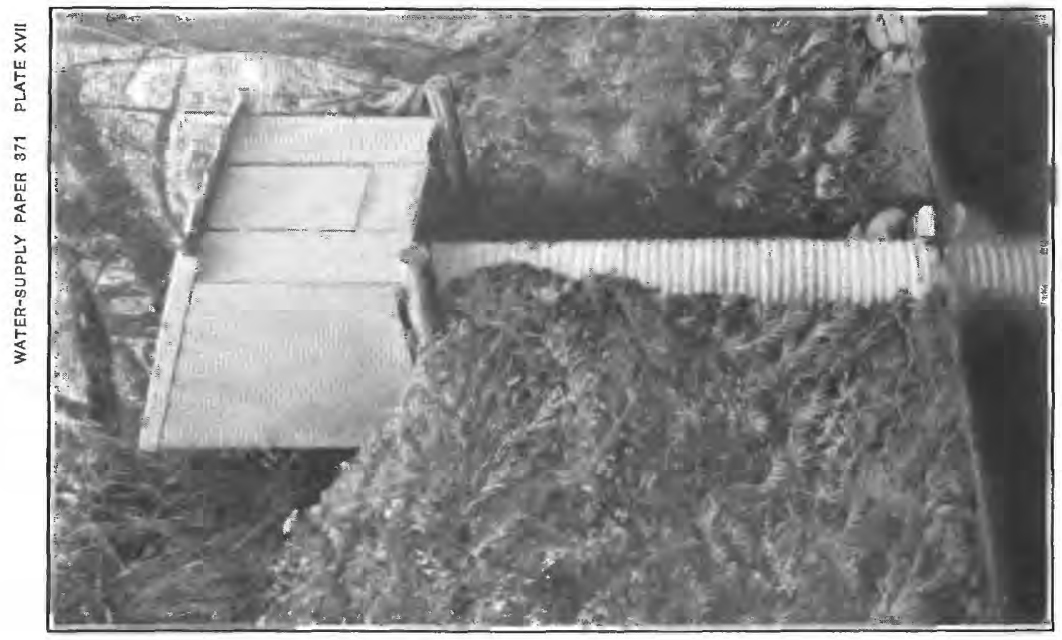

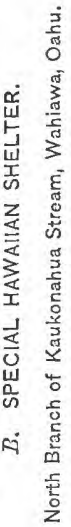

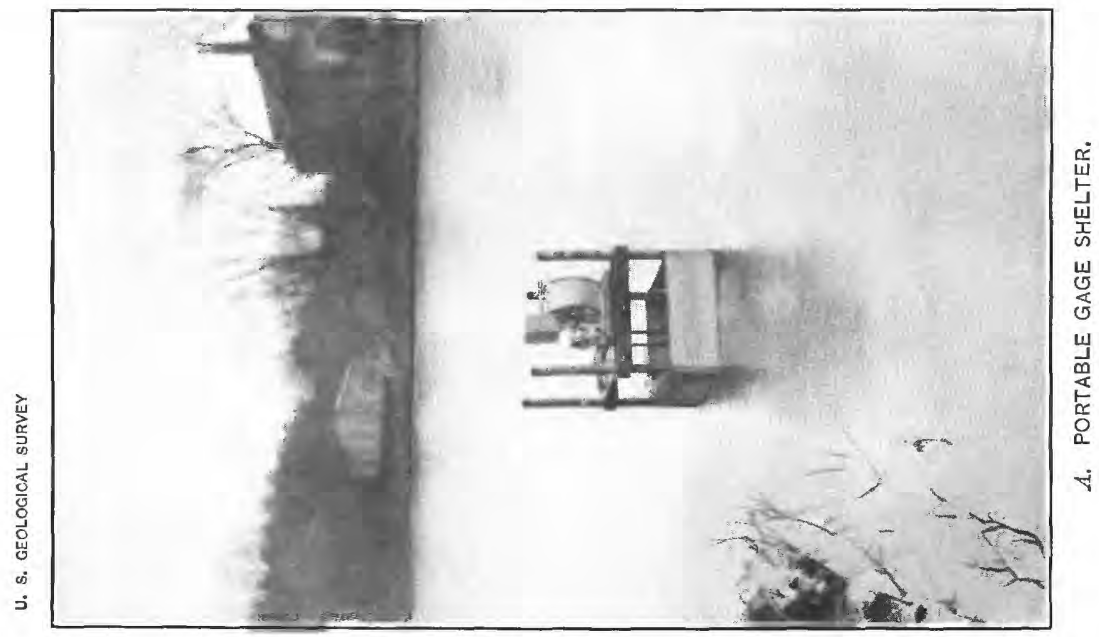


TABLE 12.-Bill of material for portable shelter.

[Lettered items refer to Plate XVIII.]

LUMBER.

Item 1. Two hardwood clamps $C, 1$ by 2 by 19 inches long.

2. Six pieces hardwood $F, \frac{1}{2}$ by 3 by 18 inches long, for deck $D$.

3. Two hardwood sills $E, 1$ by 2 by 19 inches long.

4. Four wooden stiffeners, $\frac{1}{4}$ by 1 by 18 inches long, for each section of plates.

5. Canvas cover of 18-ounce brown duck, 19 by 21 inches, height depending on kind of gage used, with holes for hasp staples, the openings protected with thin galvanized plates riveted to the canvas.

HARDWARE.

Item 6. - sections, each 4 pieces, of $\frac{3}{4}$-inch heavy galvanized wrought-iron pipe $P$.

7. Four couplings, $\frac{3}{4}$-inch, galvanized, for each section of pipe.

8. Four caps, 3 -inch, heavy, galvanized, for top section.

9. Four plates, $13 \frac{1}{2}$ by 18 inches, of No. 24 galvanized iron, with $\frac{1}{4}$-inch holes placed as shown on drawing.

10. Two hasp staples $H$, with screws, for fastening canvas cover.

11. Four carriage bolts $A, \frac{1}{2}$ inch by $4 \frac{1}{2}$ inches, with one washer and one hex nut.

12. Eight stove bolts, $\frac{3}{16}$ inch by 4 inches, with 16 washers $\frac{1}{4}$-inch and 16 wing nuts $\frac{8}{16}$ inch, for each section of plates.

13. - R. H. stove bolts, $\frac{1}{4}$ by $\frac{3}{4}$ inch, for fastening sections together and for fastening on stiffeners, with $\frac{1}{4}$-inch washers.

14. Two United States Geological Survey standard padlocks.

15. Two 8-inch Stillson wrenches.

16. One $S$ wrench to fit nuts on $\frac{1}{2}$-inch bolts.

17. One screw driver.

18. Four brass stove bolts to fasten gage to deck.

19. Three-fourths inch $F$. H. bright wood screws, for fastening deck to sills $E$.

PLANY-CONCRETE SHELTER.

The arrangement of the concrete shelter is clearly shown on Plate V, $A$ (p. 15). It should be noted, however, that in order to show the greatest number of details in the cut, the longer axes of the house and well have been turned parallel to the stream. As actually constructed the longer dimension of the well is placed at right angles to the stream and the shorter dimension parallel to the stream.

The dimensions in plan (Pl. VIII, p. 20) give ample but not excessive room inside the shelter to allow the gage to be inspected and adjusted without discomfort. In fact, it is desirable to have a clear passage all around the gage table.

The 2 by 4 inch furring strips placed in the walls afford means for fastening cupboards, etc., or for placing hooks to carry various pieces of minor equipment necessary for the operation of the station. Directly over the center of the door a half-inch eyebolt set into the concrete for carrying a pulley and rope is useful for a number of 
purposes, such as bailing the well. The stirrup to which is fastened the bed piece for the rod gage should be set into the concrete and attached by means of $\frac{1}{4}$-inch bolts. Two pieces of 2-inch pipe for ventilator should be inserted in the back and front of the walls of the house. Pipe caps should be provided to close these vents. A 3 -inch ventilator runs through the building in one corner and passes out under the eaves. In cold weather it is desirable in some localities to close all vents to prevent the water in the well from freezing.

Where the variation in stage is great it may be necessary to lift the hook gage so high that the gage rod must pass through the roof. To meet this condition a smoke jack of galvanized iron, 6 inches in diameter, may be placed directly over the gage rod and set into the roof and covered by a close-fitting cap. If necessary for the protection of the apparatus, this pipe may be locked by riveting a short piece of chain to the cover and locking it to the bed piece.

The door and window frames are shown in detail in Plate XIX. The door and window frames should be placed flush with the outside of the walls and the jambs set as shown in the details. When this has been done the 1-inch angles on the iron door and shutters will fit closely against the jambs, which will afford desirable protection against storms and cold. The windows have $1 \frac{3}{8}$-inch stock sashes, each with four lights of 8 by 10 inch glass. Stops should be screwed at the top and bottom of sash. The door should open inward and should be hung on 3 -inch butts and provided with an ordinary lock set.

In erecting the forms, care should be taken that all door and window frames are properly set and are true to shape and dimensions. The hooks for the iron door and shutter hinges should be carefully placed. As shown on the plan, these hooks have a collar welded on, which fits flush with the outside wall, and the inside is provided with a nut and an ogee washer.

A top form is necessary for the roof slab. The form for the overhanging eaves can be made of not more than two boards carried on a series of brackets nailed to the uprights supporting the forms for the walls. The uprights may be wired together to preserve the line of the walls. The pouring of the walls should be a continuous operation up to within about a foot of the top. The walls for the remaining distance and the top slab should be poured at one operation. Small holes and other defects in the face should be filled with mortar after the forms are removed. Ridges or rough places may be smoothed down with a stick of carborundum. The entire face may be painted with a coat of thin mortar. 


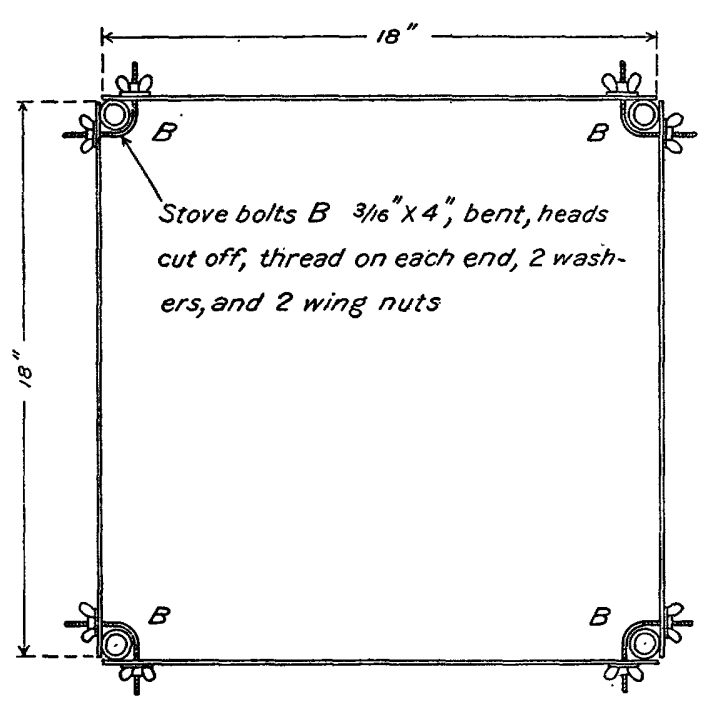

CROSS SECTION

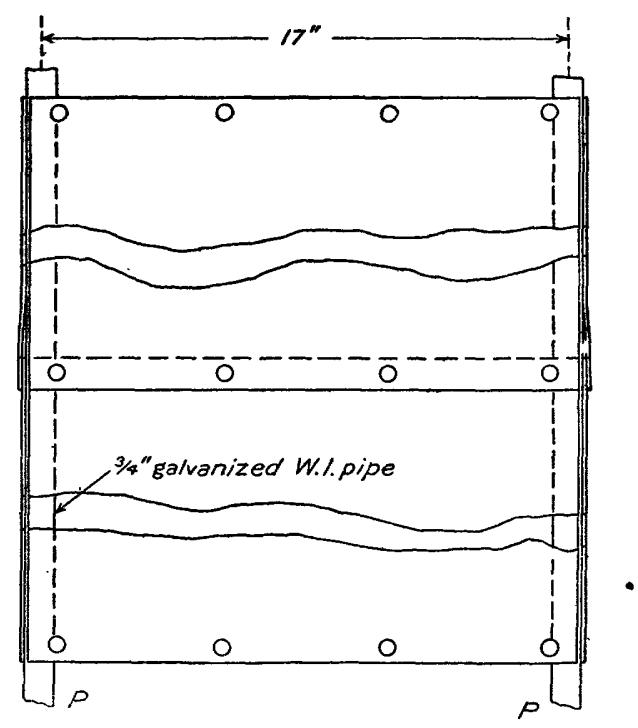

PART ELEVATION, SIDES AND ENDS

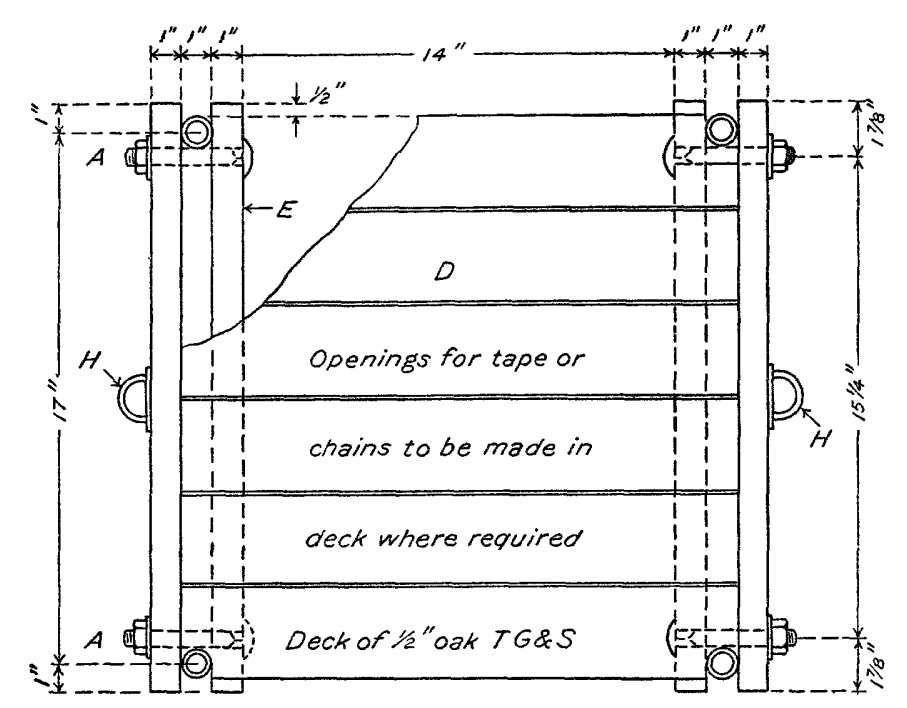

PLAN OF DECK

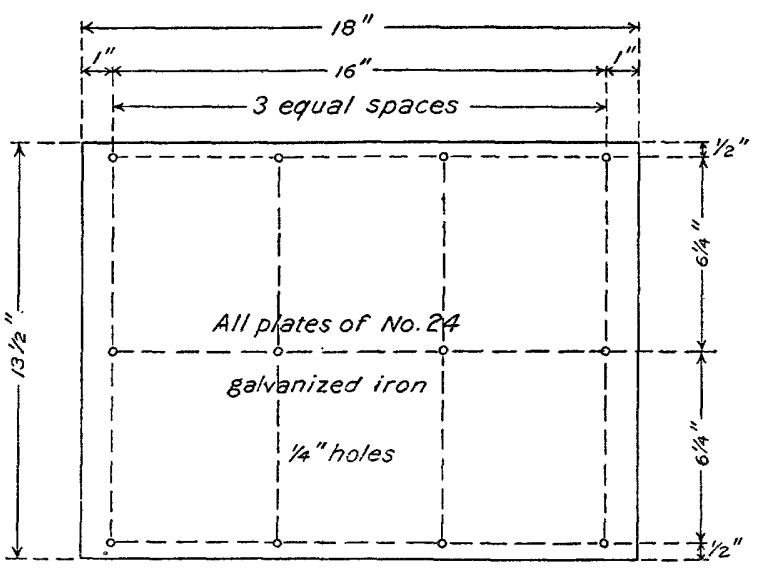

SIDE AND END PLATES

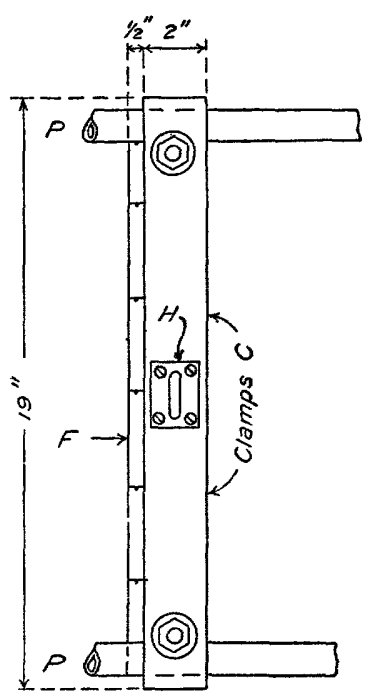

ELEVATION

PLANS OF PORTABLE SHELTER.

Bill of material given in Table 12, page 31. 
ThBLE 13,-Bill of material for concrete well and shetter for automatic recording gage.

[Lettered items refer to Plate VIII, p. 20.]

CONCRETE.

Item 1. 3.7 cubic yards 1-2-4 concrete in shelter, including floor, requiring-

22 bags cement.

$1 \frac{1}{2}$ yards sand.

3 yards $\frac{3}{4}$-inch stone or gravel.

2. 2.7 cubic yards 1-2-4 concrete for upper 3 feet of well, requiring-

- 17 bags cement.

$1 \frac{1}{4}$ yards sand.

$2 \frac{1}{2}$ yards stone.

3. 0.6 cubic yard (approximately) of 1-2-4 concrete in walls of well for each foot of depth below first 3 feet. Each cubic yard requires-

6.4 bags cement.

0.45 yard sand.

0.90 yard stone.

4. 1.2 cubic yards 1-3-6 concrete in foundation, requiring-

6 bags cement.

$5 \frac{2}{3}$ yards sand.

$11 \frac{1}{3}$ yards stone.

5. $62 \frac{1}{2}$ square feet Clinton wire cloth or substitute for reinforcing roof and floor.

6. One wooden doorframe $D 1$, with door complete, with lock set, hinges, and four lights of glass.

7. One iron door $D 2$, as shown on drawing, painted with one coat of Dixon's graphite paint, complete, with two staples for padlocks.

8. Eight hooks $H 1$, fitted to hinges, with collars welded on, and furnished with nuts and ogee washers.

9. Three window frames $Q$, with sashes, complete.

10. Three iron shutters $D Z$, as shown on drawing, painted with one coat Dixon's graphite paint, with 6 staples for padlocks.

11. Four United States Geological Survey standard padlocks.

12. One lifting ring $U$, for trapdoor, with screws.

13. One pair 6-inch strap hinges $H$, with 4-inch stove bolts for all holes.

14. Two pieces light rail $C$, for door rest, each $3 \frac{1}{2}$ feet long.

15. 1 pound $1 \frac{1}{2}$-inch ( 6 d.) nails, for trim.

16. Six pieces 3 -inch galvanized wrought-iron pipe for ventilator, cut as follows:

One piece 6 feet 3 inches long, $O$, threaded one end.

One piece 1 foot long, 01 , threaded one end.

One piece 2 feet long, 02 , threaded one end.

One piece 1 foot long, 03 , threaded both ends.

One piece 2 feet long, 04 , threaded both ends.

One piece 7 inches long, 05 , threaded one end.

17. Four 3-inch galvanized elbows $N N 1 N 2 N 3$.

18. One 3-inch galvanized return bend $B$.

19. Four pieces 2 -inch galvanized wrought-iron pipe $V, 8$ inches long, threaded one end, with four 2-inch galvanized caps, or else grid ventilators, if desired.

20. One 6-inch smoke jack $S J$, with cap, as shown, over hook gage. (Use where hook gage rises above roof.)

21. One piece $\frac{1}{4}$ by 2 inches iron, 2 feet long, $S$, for stirrup.

22. One eyebolt $E$, $\frac{1}{2}$ by 6 inches, with nut and 4 by 4 by $\frac{3}{8}$ inch square washer. 97886 ${ }^{\circ}$ W S $371-15-3$ 
Item 23. — pieces $R$, 1-inch iron 3 feet long, for steps, inner edge to set 3 inches from face of wall.

24. - one-half inch bolts $J$, with nuts and washers, to hold bed piece to wall.

25. Two machine bolts $S 1, \frac{1}{4}$ by $3 \frac{1}{2}$ inches, with washers to fasten bed piece to stirrup.

26. 1-gallon carbolineum for treating gage rod, table, etc:

27. 1 gallon gray mixed paint for door, window, etc.

MATERIAL FOR CAST-IRON INTAKE PIPE, ANChORAGE, ETC.

Item 28 . One 4 by 4 by 4 inch C. I. T, $P T$, for intake.

29. 1 square foot $\frac{1}{2}$-inch mesh galvanized-iron wire screening.

30. 5 feet No. 10 galvanized wire.

31. One-half pound oakum and 5 pounds lead for each joint to be calked.

32. - bags cement for concrete for intake anchorage.

33. - cubic yards sand for concrete for intake anchorage.

34. - cubic yards gravel or broken stone for concrete for anchorage.

35 . One 4-inch sluice valve $G$, with body of proper length.

36. - feet $\frac{1}{2}$-inch galvanized pipe $P 1$, for valve stem.

37. - lengths 4-inch standard-weight cast-iron pipe $P 2$, for intake pipe.

38. Five straps and 10 anchor bolts $P S$, with nuts for holding intake to anchor.

Note.-When wrought-iron pipe is used, omit oakum and lead.

LUMBER.

Item 39. One piece lumber 2 by 6 inches by 14 feet, for trapdoor $T$.

40. Two pieces lumber 2 by 4 inches by 12 feet, for furring strips $A$.

41. Two pieces lumber 2 by 4 inches by 14 feet, for furring strips $A$.

Note.-All lumber throughout the building and well shall be the best of the several kinds, thoroughly seasoned, free from large or unsound knots, saps, shakes, wanes, dry rot, or other imperfections impairing its strength or durability or affecting its appearance for the purpose for which it is to be used.

42. One standard gage table. (See Table 15, p. 38.)

43. One standard hook gage. (See Table 1, p. 9.)

FORMS.

[See p. 38.]

For a well 12 feet from bottom of floor to top of footing:

Item 44. Forty pieces 2 by 6 inches by 16 feet ( 640 feet b. m.), from which cut-

Four pieces 8 feet 5 inches long, frames under bottom of house, outside.

Four pieces 7 feet 5 inches long, frames under bottom of house, outside.

Eight pieces 8 feet 3 inches long, outside frames for house.

Eight pieces 7 feet 3 inches long, outside frames for house.

Five pieces 5 feet 10 inches long, inside frames for house.

Ten pieces 4 feet 10 inches long, inside frames for house.

- jack rafters to support edge form on roof.

Six pieces 2 feet 4 inches long, beams under floor.

Two pieces 8 feet 5 inches long, top outside corbel frame.

Two pieces 7 feet 5 inches long, top outside corbel frame.

Two pieces 8 feet 5 inches long, middle corbel frame.

Two pieces 6 feet 3 inches long, middle corbel frame.

Fourteen pieces 5 feet 4 inches long, outside well frame.

Fourteen pieces 8 feet 10 inches long, outside well frame.

Eighteen pieces 2 feet 4 inches long, inside well frame. 


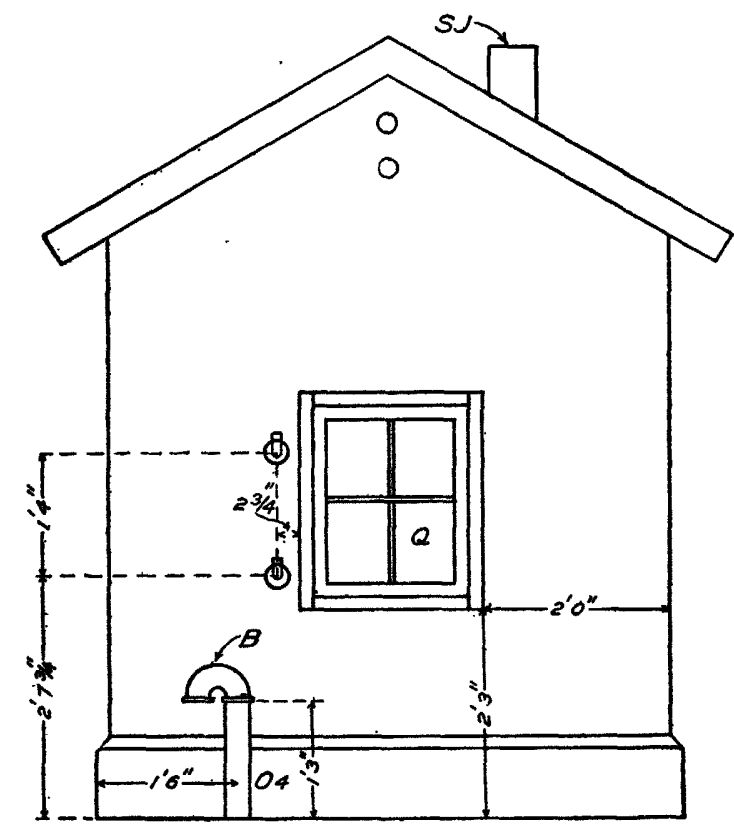

REAR ELEVATION

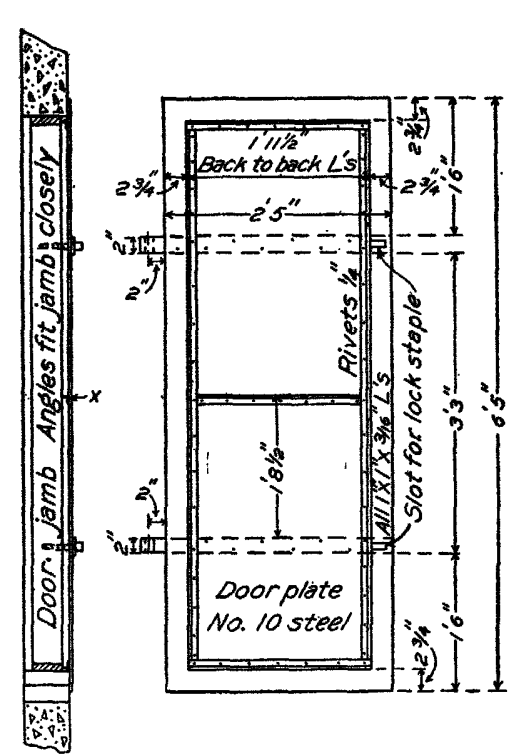

DETAILS OF IRON DOOR DZ

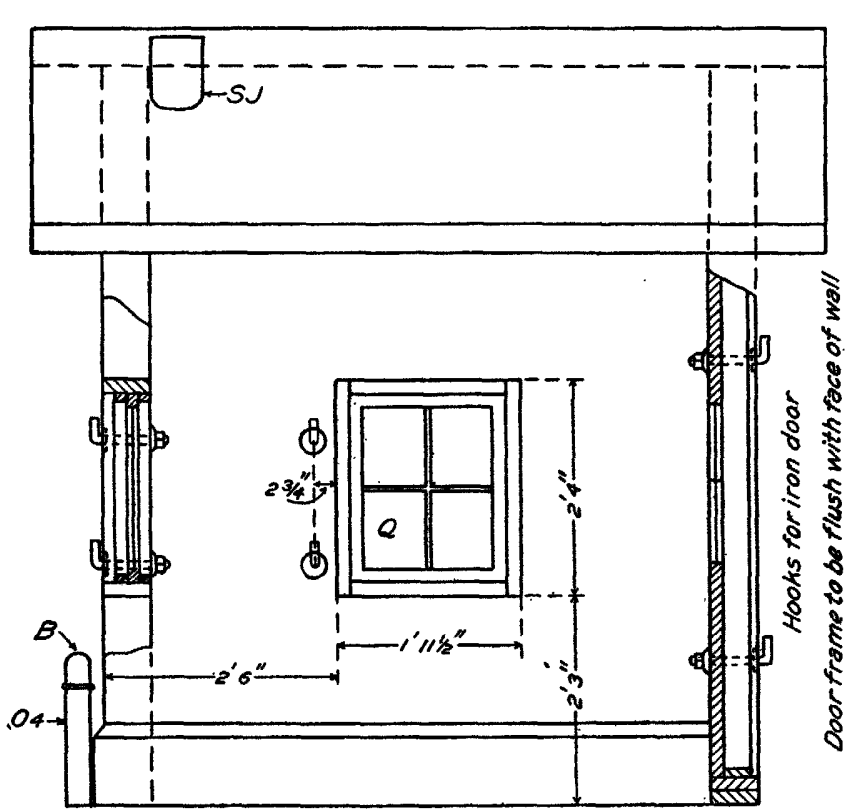

SIDE ELEVATION
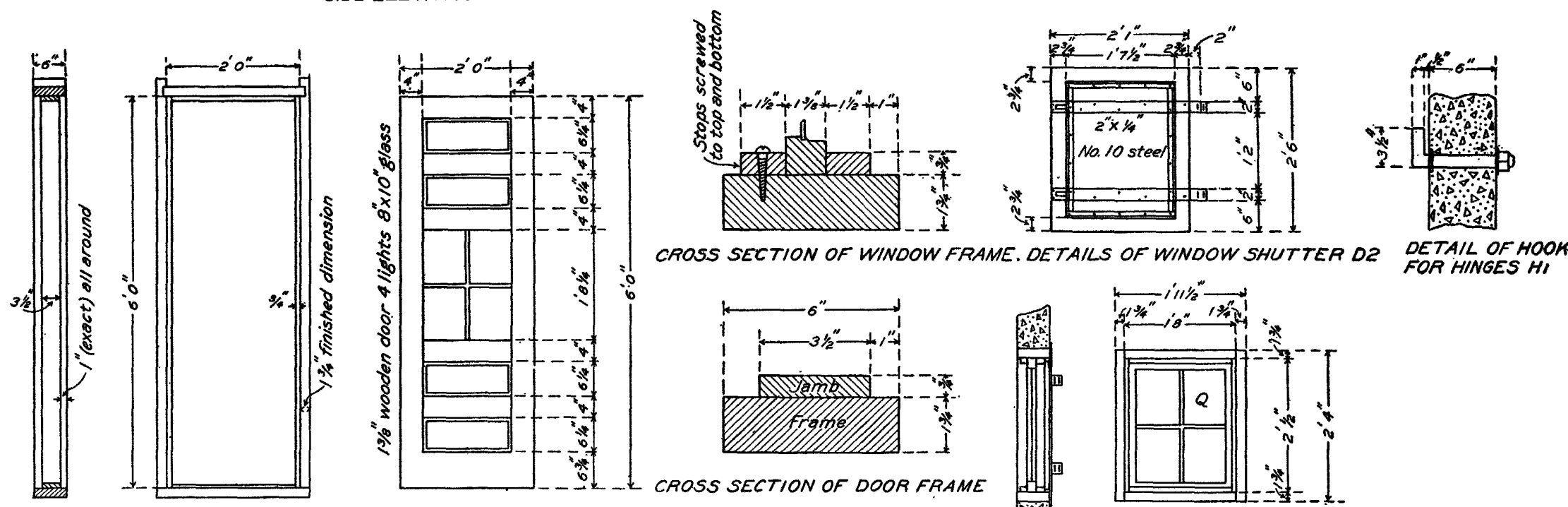

CROSS SECTION OF WINDOW FRAME. DETAILS OF WINDOW SHUTTER DZ
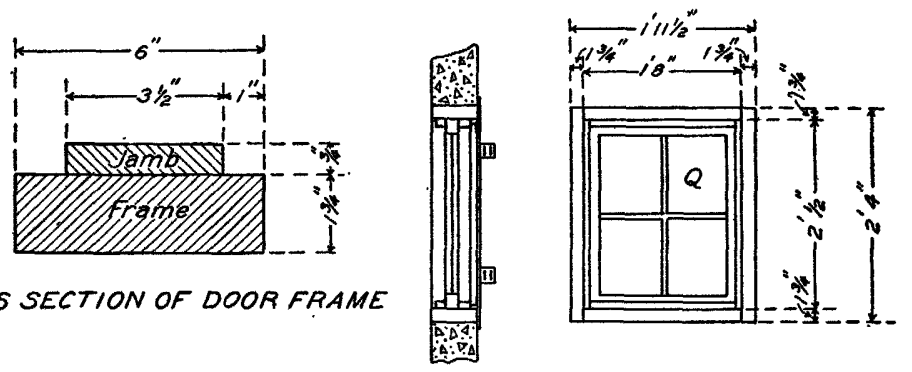

WINDOW DETAILS

PLANS OF PLAIN-CONCRETE HOUSE, SHOWING ELEVATIONS, DETAILS OF DOOR AND WINDOW SASHES, AND IRON DOOR AND SHUTTERS. 
Item 45 . Sixteen pieces 2 by 6 inches by 12 feet (192 feet b. m.), from which cutFive pieces 5 feet 10 inches long, inside frames for house.

Nine pieces 5 feet 10 inches long, beams under roof forms.

Eighteen pieces 5 feet 10 inches long, inside frames for well.

46. Four pieces 2 by 4 inches by 12 feet ( 32 feet $\mathrm{b}$. $\mathrm{m}$.), from which cut-

Four pieces 3 feet long, inside cleats bottom of roof.

Four pieces 5 feet long, outside cleats bottom of roof.

Two pieces 5 feet 10 inches long, cleats under floor beams.

47. 1,100 feet b. m. 1-inch T. G. \& S. or S. L. S. sheathing.

48. Braces and cleats in forms for footing.

49. - telephone wire to tie forms together.

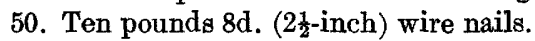

51. Five pounds $20 \mathrm{~d}$. (4-inch) wire nails.

52. For each additional foot of depth of well increase item 43, 1-inch sheathing, by 50 feet $\mathrm{b}$. m., and dimension lumber according to depth.

Note.-In these forms the sheathing for both well and house is placed vertically on the 2 by 6 inch framing pieces, which are placed horizontally. If necessary, 6 by 8 inch wale pieces, placed vertically, may be used to preserve the alignment of the forms.

SUMMARY OF LUMBER IN FORMS FOR A 12-FOOT WELL.

In well:

Feet b. m.

1-inch sheathing.

620

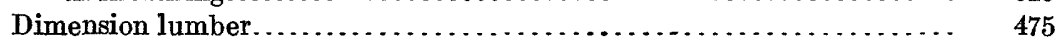

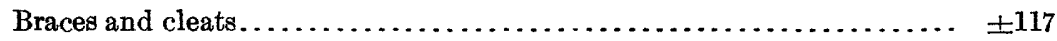

In shelter:

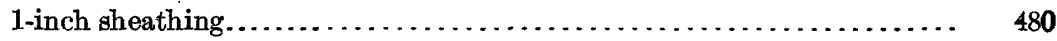

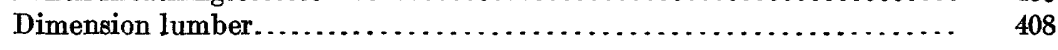

$\pm 2,100$

NoтE.-This bill includes a reasonable allowance for cuts, undersized pieces, and mistakes, but the cutting scheme shown in the table should be followed carefully.

RERTFORCED-CONCRETE SHELTER.

If a reinforced-concrete shelter is desired, it should be built according to the plans shown in Plate IX (p. 20), in which all dimensions are given. The window frames (Pl. X, $A, \mathrm{p} .22$ ), which are of metal and contain wire screens, may be obtained from stock at builders' supply houses. Ventilators of pressed steel of a style similar to the window frames may also be obtained. A suitable fireproof door may be made by covering with block tin an ordinary door built of planks.

General directions for building the necessary forms are given on page 38. 
TABLE 14.-Bill of material for reinforced-concrete shelter for automatic recording gage.

[Lettered items refer to Plate IX, p. 20.]

CONCRETE.

Item 1.7 .9 cubic yards of 1-2-4 concrete, in shelter, corbel, and footing, requiring50 bags Portland cement.

4 cubic yard clean sharp sand.

8 cubic yard clean gravel or broken stone.

2. 23.8 cubic feet of concrete for each linear foot of well between bottom of corbel and top of footing course. Each cubic yard of concrete requires-

6.4 bags of Portland cement.

0.45 cubic yard of clean sharp sand.

0.90 cubic yard of clean gravel or broken stone.

STEEL REINFORCEMENT.

Use half-inch square deformed bars, unless otherwise specified. A lap.of 2 feet is allowed to develop full strength of bars.

Item 3. Eighteen bars $C 1,4$ feet 10 inches long, joining walls to footing.

4. Four bars $C 2,14$ feet long, two at base of house and two over door.

5. Two bars $C 3,12$ feet 2 inches long, in corbel at top of well.

6. Two bars $C 4,10$ feet 4 inches long, in corbel at top of well.

7. - bars C4, 10 feet 4 inches long, in well, spaced as depth of well may require.

8. Six bars $C 5,11$ feet 6 inches long, in side walls of house.

9. Two bars $B 1,8$ feet 6 inches long, placed lengthwise in footing.

10. Four bars $B 2,7$ feet 6 inches long, placed crosswise in footing.

11. Thirty-four bars $B 3,7$ feet long, in corbel at top of well.

12. Thirty-four bars $B 4$, three-eighths inch square, 2 feet long, stirrups in footing.

13. - bars $B 5$, three-fourths inch round, 3 feet long, for steps, set 12 inches on centers, and with inner edge 3 inches from face of wall.

14. Fifteen bars $B 6,4$ feet long, to tie house to well.

15. Seven bars $S 6,7$ feet 8 inches long, placed lengthwise in roof.

16. Eight bars $S 7,6$ feet 8 inches long, placed crosswise in roof.

17. Sixteen bars $S 4,7$ feet 10 inches long, placed vertically in walls.

18. Two bars 6 feet 8 inches long, with ends hooked, placed over doors, back of $C 2$.

19. One bar 6 feet 8 inches long, bent into four lengths and placed in doorstep.

20. Two bars $S 3,6$ feet long, crosswise in floor over well.

21. Six bars $S 1,6$ feet 4 inches long, lengthwise in footing.

22. Six bars $S 2,5$ feet 6 inches long, crosswise in footing.

23. Eighteen bars $S 8$, of proper length, placed vertically in walls of well.

24. - $\frac{3}{8}$-inch hook bolts with nuts and one washer each to fasten staff gages to well.

25. One United States Geological Survey standard padlock.

26. Lifting ring and hinges for trap door. (See Table 13.)

27. Intake and valve. (For items see Table 13.)

28. One standard gage table (Table 15).

29. One standard hook-gage outfit (Table 1).

30. Carbolineum or other wood preservative for treating gages and gage table.

31. Necessary ventilators. 


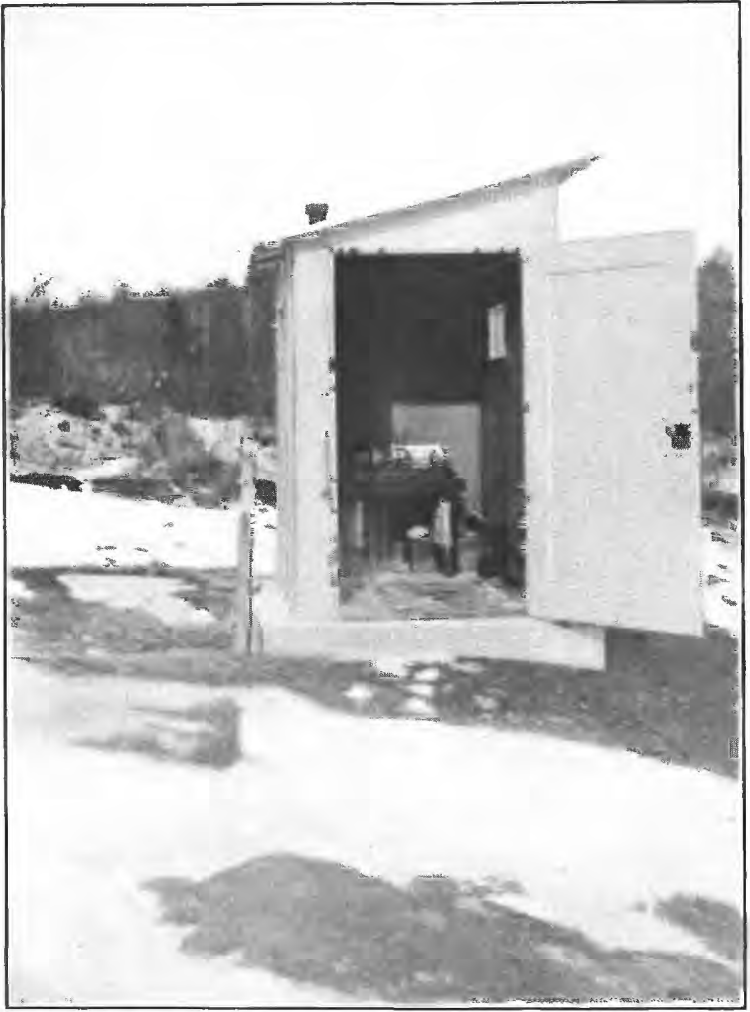

A. METAL SHELTER ON CONCRETE WELL.

Raquette River at Piercefield, N. Y.

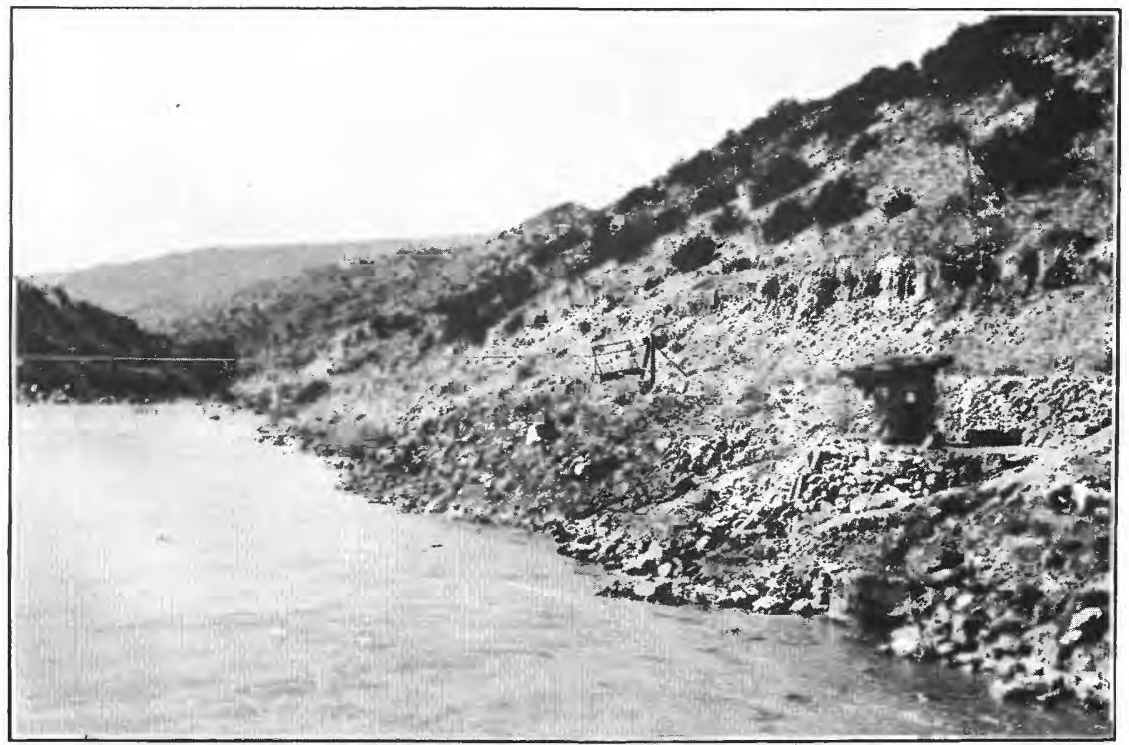

$b$. SPECIAL SHELTER OF STONE.

Rio Grande at Embudo, N. Mex. 


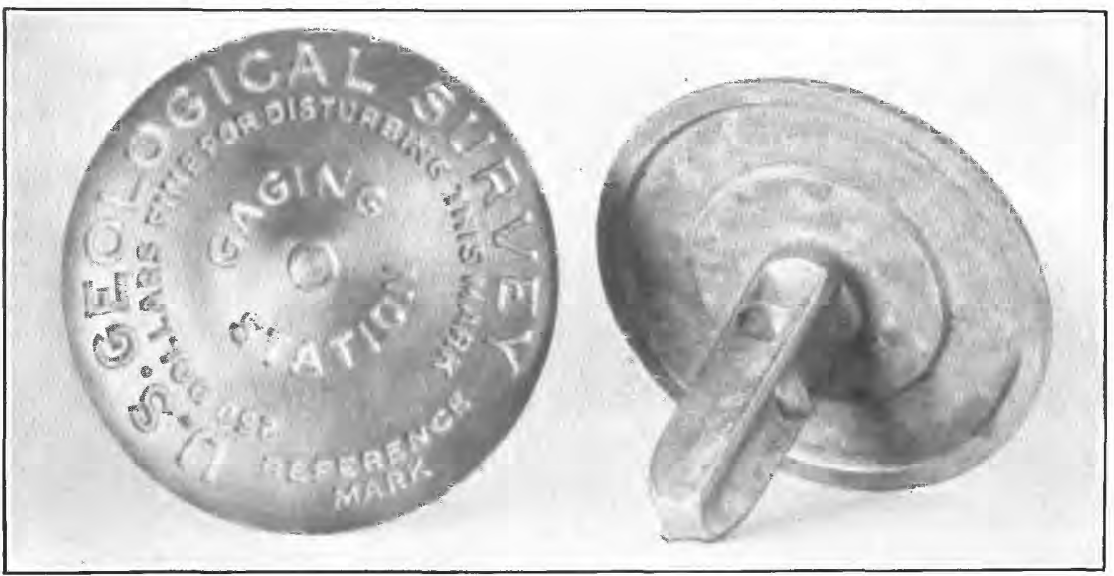

A. WATER RESOURCES BENCH-MARK TABLET.

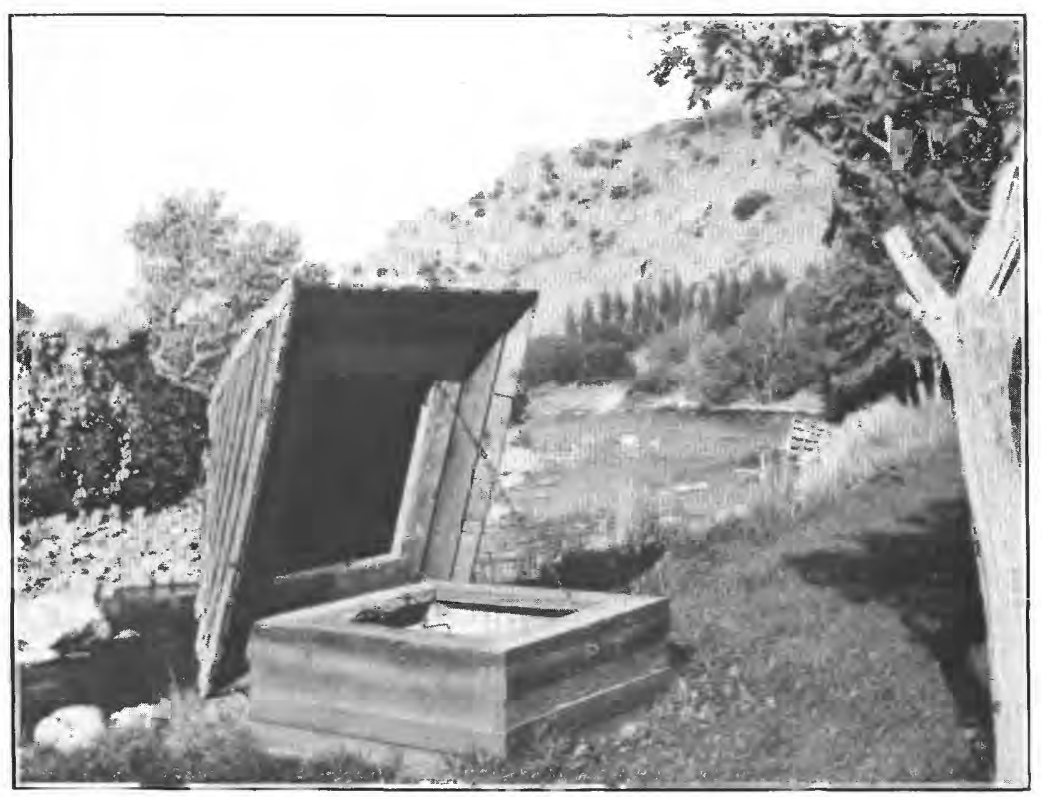

B. LOW SHELTER.

Logan River at Logan, Utah. 
It is occasionally necessary to use local material, such as stone, brick, or wood-stave pipe, for building the shelter. The shelter shown in Plate XX, $B$, is built of stones backed by concrete. The roof is made of tile to avoid damage by fire from locomotive sparks. The wooden door is covered with tin, which is painted. In building the house, forms were made for the inside and mortar was poured between them and the stone wall. The resulting wall, which was fairly smooth, was painted with a finishing coat of thin grout. The well beneath this shelter is lined with concrete. A circular ventilating opening, 6 inches in diameter, is carried up through one of the walls and opens into the air about 2 feet below the roof.

A shelter that has proved satisfactory in Hawaii is shown in Plate XVII, $B$ (p. 31). The frame, which is built of pine, is of standard dimensions and is covered with rubberoid roofing paper. At one station the wood-stave pipe used as the well lining was carried above the ground to form the shelter.

The combination of a concrete-lined well with either a wooden or a metal shelter, as shown in Plate XX, $A$, may be made to advantage.

A special form of shelter is shown in Plate XXI, $B$, under the tree to the left of the tailrace of the power station.

Shelters of other types are shown in Plates XXII, XXIII, and XXIV.

VENTILATION.

Excess moisture has caused inconvenience and in some places difficulty in automatic-gage shelters.

In warm weather the moisture rusts tools or iron parts and also distorts the hydrograph paper. At stations where the temperature is above freezing throughout the year the excess moisture may be prevented by making openings on all sides near the top, at the base, and under the eaves of the shelter, thus maintaining free circulation of air across the top of the well and through the shelter. The openings may be protected with a woven-wire, metal, or wooden-slot screen. Dust should be kept out of the shelter by stretching a piece of cheesecloth or thin muslin over the ventilators in the house.

Where the station must be maintained during cold weather the problem is more difficult. The well is then relatively warm and the air in it is saturated with moisture; the house under ordinary circumstances is relatively cold. Whenever saturated air from below enters the shelter it loses its surplus moisture on cooling, sometimes depositing frost on the tape operating the gage mechanism, causing the tape to freeze to the frame of the machine, and thus giving an erroneous record. To permit free circulation of air when the temperature is below freezing is out of the question, for the water in 
the well will freeze when exposed. If, on the other hand, the temperature in the shelter is higher than the temperature in the well, air which is saturated at the well temperature will not be saturated at the higher temperature of the shelter. The remedy in this case will be to have the temperature in shelter at least as high as that in the well, a condition that may be attained by building for warmth or by heating, or both, according to the prevailing winter temperature at the station. Though air circulation is desirable, frequent changes of air in cold weather and the consequent cooling of the temperature of the house will defeat the purpose sought. The ventilators in wells and shelters used in both hot and cold weather should therefore be so arranged that they may be freely used in warm weather and closed tight in cold weather.

\section{GAGE TABLE.}

The gage table is best made of three layers of 1-inch material, the middle layer running across the top and bottom layers, both of which run in the same direction. The three layers should be fastened together by $1 \frac{1}{2}$-inch screws, passing from the middle layer into the top and from the bottom layer into the middle, thus leaving a smooth top surface on which to set the gage. In placing the screws the location of the chain openings should be kept in mind.

The adjustable standard legs for the table are made of pieces of $1 \frac{1}{2}$-inch galvanized pipe 24 to 30 inches long, threaded on both ends, the threads being cut long and to a tight hand fit. One thread must have a left-hand and the other a right-hand thread. These threads fit into $1 \frac{1}{2}$ by 5 inch floor flanges, four of which are fastened to the floor and four to the under side of the gage table. One set of four flanges must have left-hand threads.

\section{TABLE 15.-Bill of material for standard gage table.}

[Lettered items refer to Plate VIII, p. 20.]

Item 1. Four floor flanges $M, 1 \frac{1}{2}$ by 5 inches, with right-hand thread.

2. Four flanges $M 1,1 \frac{1}{2}$ by 5 inches, with left-hand thread.

3 . Four pieces $1 \frac{1}{2}$-inch galvanized wrought-iron pipe $P, 24$ inches long, with one right-hand and one left-hand thread on each. The threads are to be cut 2 inches long and are to be fitted in the shop to a tight hand fit.

4. One-half gross F. H. No. 14 wood screws, 2 inches long, for screwing flanges to table and for making trapdoor.

5. One-half gross F. H. No. 10 wood screws, $1 \frac{1}{2}$ inches long, for making gage table.

6. Two pieces cypress, or other wood, 1 by 6 inches by 12 feet, for gage table $Y$.

\section{FORMS.}

In building concrete wells forms for both outside and inside will ordinarily be necessary. In some places a single board on each side, against which the back filling is made, may serve as the outer form, 


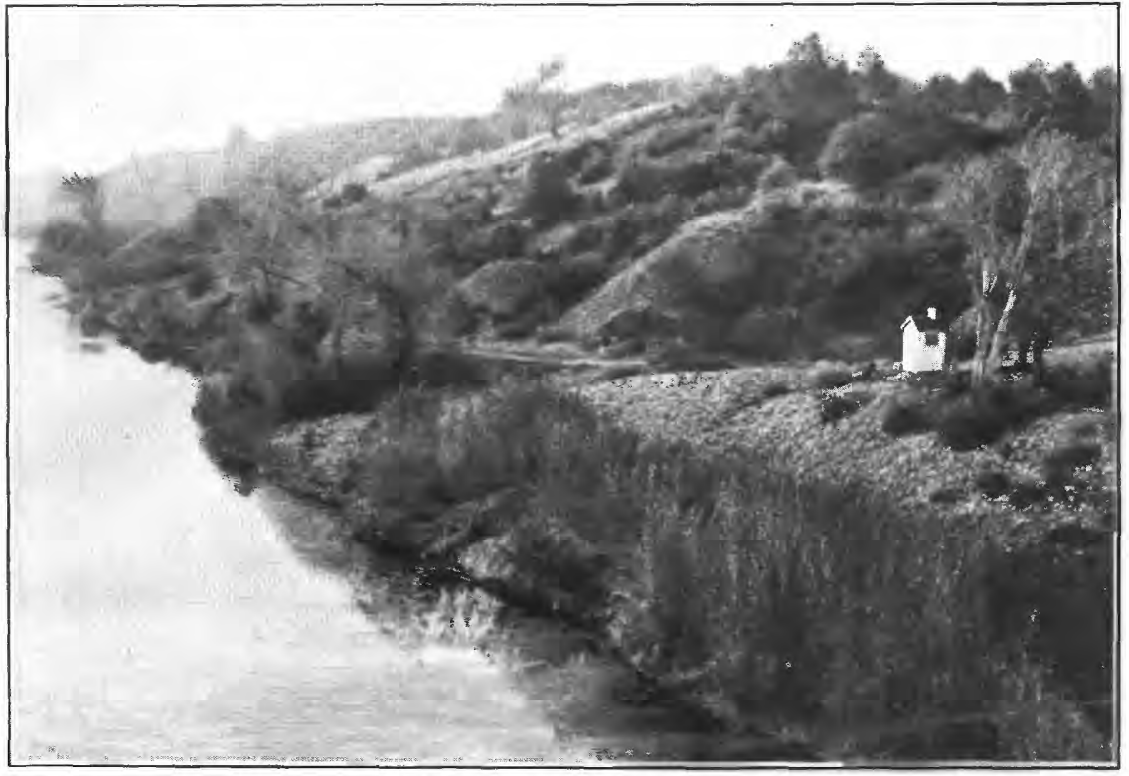

A. FEATHER RIVER AT OROVILLE, CAL.

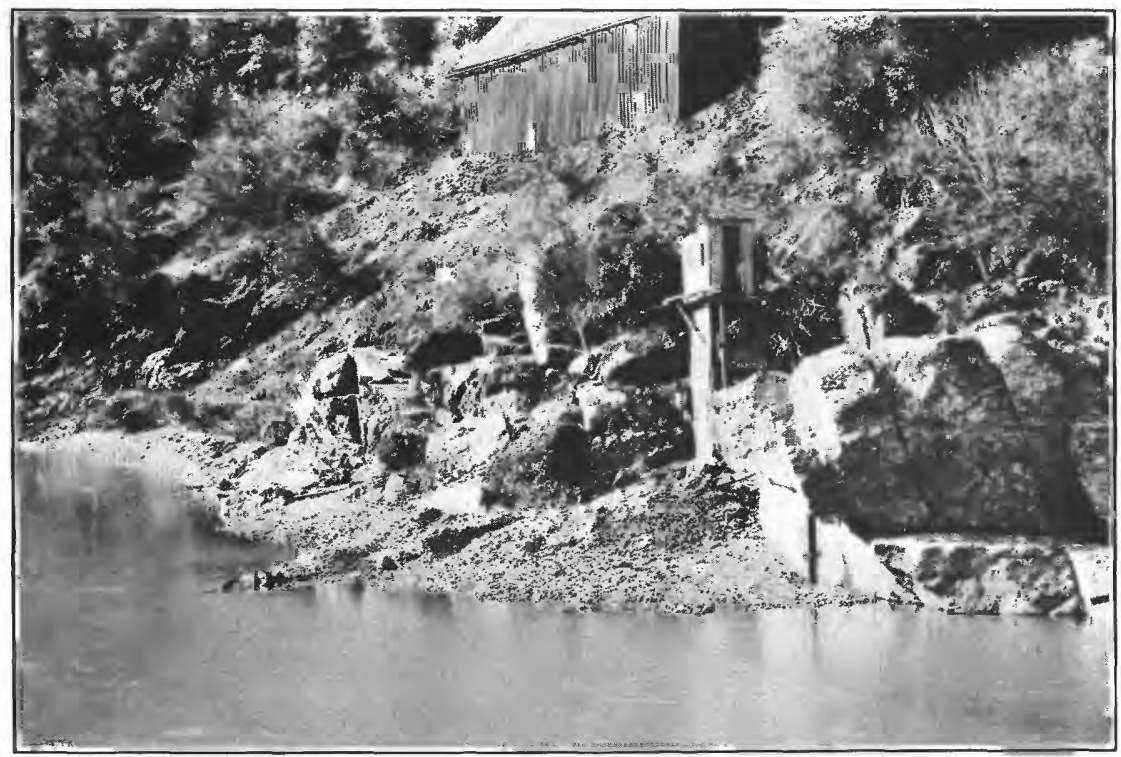

B. NORTH FORK OF AMERICAN RIVER AT COLFAX, CAL.

AUTOMATIC-GAGE SHELTERS. 


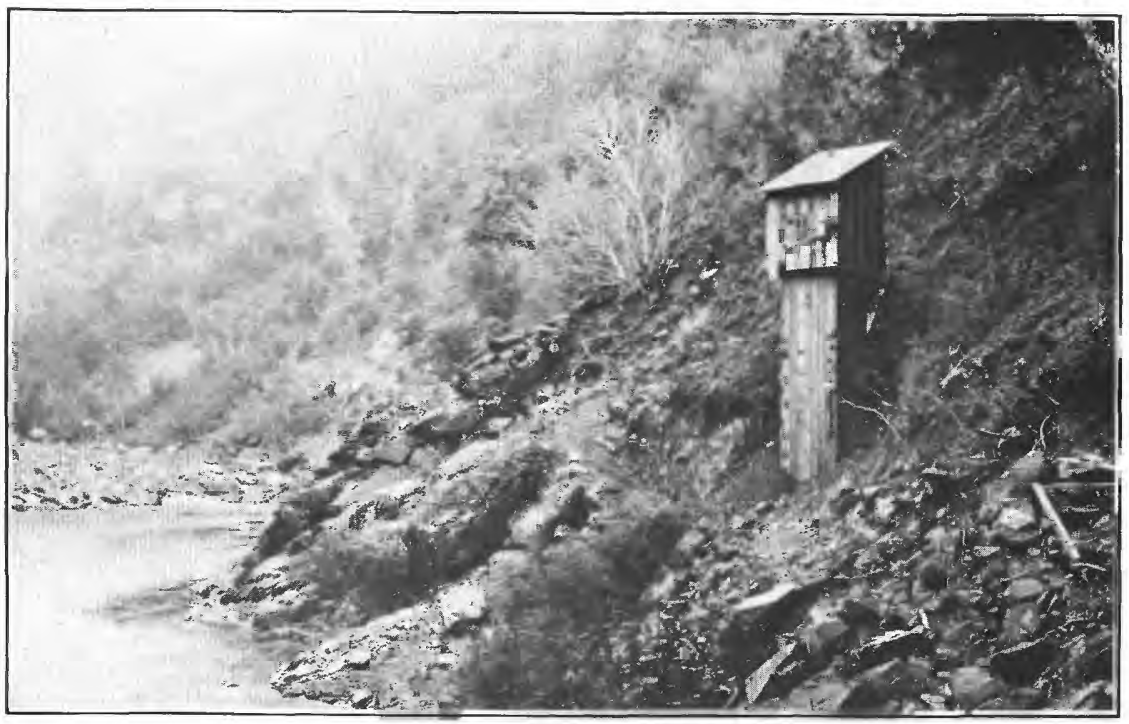

A. TUOLUMNe RIVER AT GROVELAND, CAL.

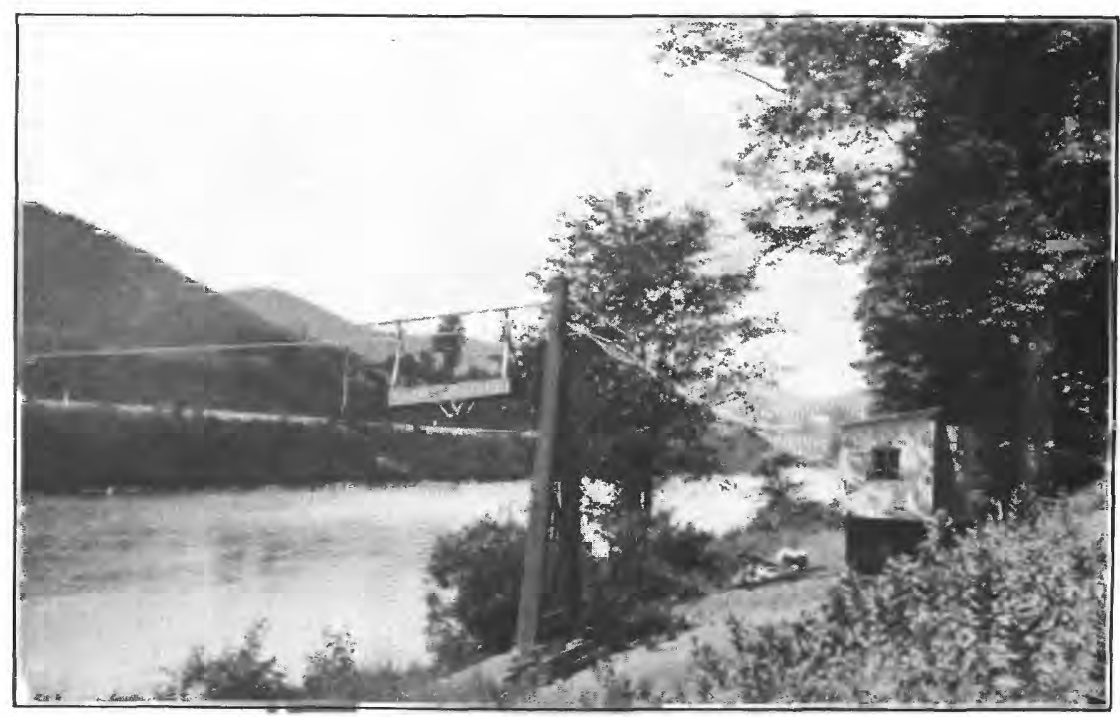

B. DEERFIELD RIVER AT CHARLEMONT, MASS.

AUTOMATIC-GAGE SHELTERS. 
the boards being drawn up as the work progresses. It is highly essential that the forms used should be tight; that is, the lumber used for the forms should contain no large checks or knot holes. Rough, cheap lumber may, however, be made into smooth forms by covering it with building paper. If reinforcing bars are used, care should be exercised to preserve the alignment of the bars while the forms are being filled. If expanded metal screen is used, the stone of the aggregate should be small enough to pass the mesh of the expanded metal; otherwise the stones will arch behind the metal and the concrete will be coarsely porous. A paddle made of 1 -inch board may be used to urge the concrete into angles and recesses.

The floor of the shelter may be finished smooth with a trowel or moderately rough with a float, which may be made. In pouring the floor and the roof, care should be taken to use only material of a pasty consistency. The use of material that is soupy will result in a slippery slime. When the concrete has set before the forms have been filled it is necessary, before the work is continued, to remove all laitance down to unquestionably good concrete, to wash the surface with clean water, and then to paint it with rich grout. The exterior of the shelter may be finished smooth by the use of carborundum finishing bricks, which are purchasable in any supply house.

The sluice valve and the iron steps must be placed in the inside forms. The use of narrow boards, with joints at the steps if possible, will facilitate the removal of the forms. Bolts half an inch in diameter, placed at 4-foot centers, should be provided for the attachnent of the bed piece for the hook gage. They should project such a distance from the wall that they will not reach the surface of the bed piece, which should be countersunk for the nuts. Expansion bolts of the anchor type will be found convenient. A line of furring strips similar to those shown in the shelter (P1. VIII, p. 20) would be convenient if placed around the well about 3 feet below the floor. A hook should also be provided in the wall over the sluice valve to hold the valve stem, which should have a handle at its upper end. A very satisfactory valve stem may be made of half-inch galvanized pipe, with a forked end for fastening to the valve welded to one end and a handle welded to the other.

Openings necessary for ventilation should be provided for during construction.

The following designs for forms have been prepared for slow filling, as by hand from a small mix. Where conditions are such that the forms may be filled rapidly, as from a power mixer, the collars around the sheathing should be placed closer together to prevent bulging.

For the footing an outside form is built of sheathing braced against the pit. 
The outside forms for the well box consist of frames of 2 by 6 inch piece laid flat, nailed together, and sheathed on the inside edges with planed 1-inch tongued-and-grooved or ship-lap boards placed vertically. The inside well forms are made of frames of material of the same size as used in the outside forms, the sheathing being in this case on the outside of the form. The alignment of the well forms is preserved by the use of 6 by 8 inch vertical waling strips.

The panel effect on the outside of the walls of the house is obtained by nailing strips of proper thickness to the 2 by 6 inch vertical studding before applying the sheathing horizontally. The 6 by 8 inch pieces are placed horizontally as collars around the forms for the house.

The first stage in pouring the concrete consists in bringing the walls and corbels up to the top of the floor, finishing the top surface, and leaving the tie rods $B 6$ sticking up out of the concrete.

The forms are then built for the walls and roof, after which they are poured in one uninterrupted operation.

For the bottom of the floor of the concrete house the form consists of 1 -inch sheathing nailed to 2 by 4 inch beams, resting on other 2 by 4 inch cleats, which are nailed to the sheathing for the well form. Forms for the roof are built of 1-inch sheathing supported by 2 by 6 inch beams nailed to the studs of the wall forms.

\section{TABLE 16.-Bill of material for concrete forms for reinforced-conerete well and shelter.}

This bill of material for lumber for forms is prepared for a well measuring 12 feet from the bottom of the corbel to the top of the footing.

Item 1. Twenty-three pieces 2 by 6 inches by 14 feet ( 322 feet b. m.), from which cutEighteen pieces 3 feet $10 \frac{1}{2}$ inches long, frames inside of well.

Eighteen pieces 2 feet $10 \frac{1}{2}$ inches long, frames inside of well.

Fourteen pieces 6 feet 8 inches long, frames outside of well.

Fourteen pieces 5 feet 8 inches long, frames outside of well.

2. Twenty-two pieces 2 by 6 inches by 16 feet (352 feet b. m.), from which cut-

Twenty-two pieces 8 feet long, studs outside of house.

Eighteen pieces 7 feet 6 inches long, studs inside of house.

Five pieces 5 feet long, under roof.

3. Two pieces 2 by 4 inches by 16 feet ( 21 feet b. m.), from which cut-

Two pieces 8 feet 2 inches long, frame outside of corbel.

Two pieces 7 feet 2 inches long, frame inside of corbel.

4. Three pieces 2 by 4 inches by 14 feet ( 28 feet $\mathrm{b}$. $\mathrm{m}$.), from which cut-

Two pieces 7 feet 2 inches long, frame outside of corbel.

Two pieces 6 feet 2 inches long, frame outside of corbel.

Three pieces 3 feet long, under floor.

5. Twelve pieces 6 by 8 inches by 14 feet ( 672 feet b. m.), from which cut-

Six pieces 8 feet long, waling strips outside of house.

Six pieces 9 feet long, waling strips outside of house.

Six pieces 4 feet long, waling strips inside of house.

Six pieces 5 feet long, waling strips inside of house. 


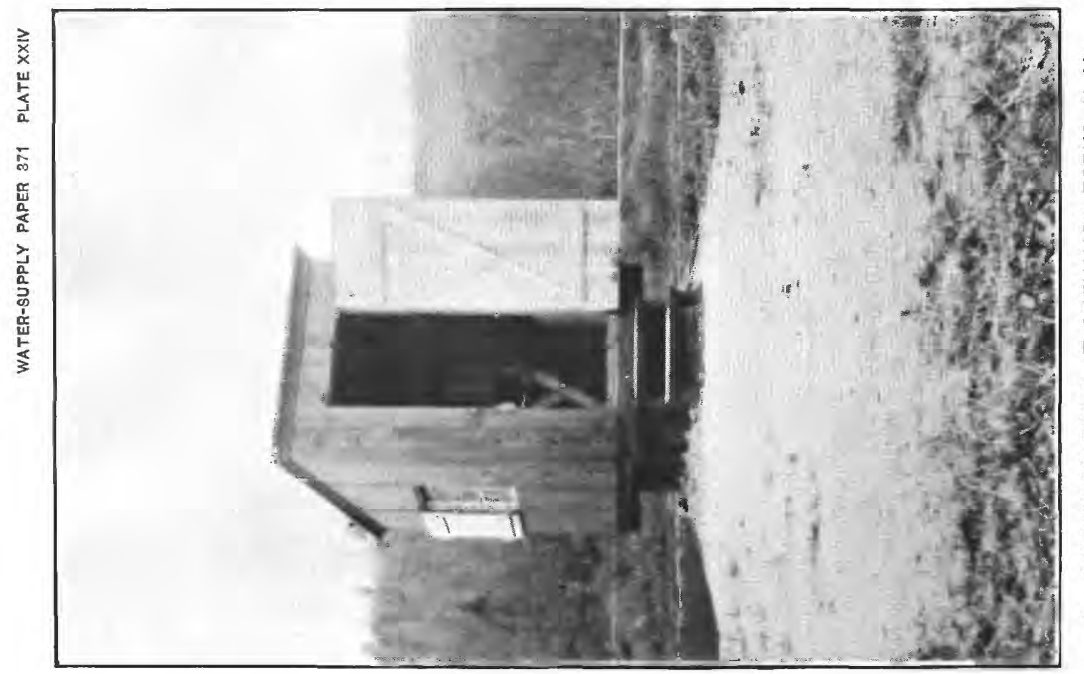

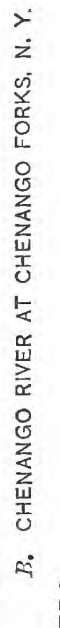

它

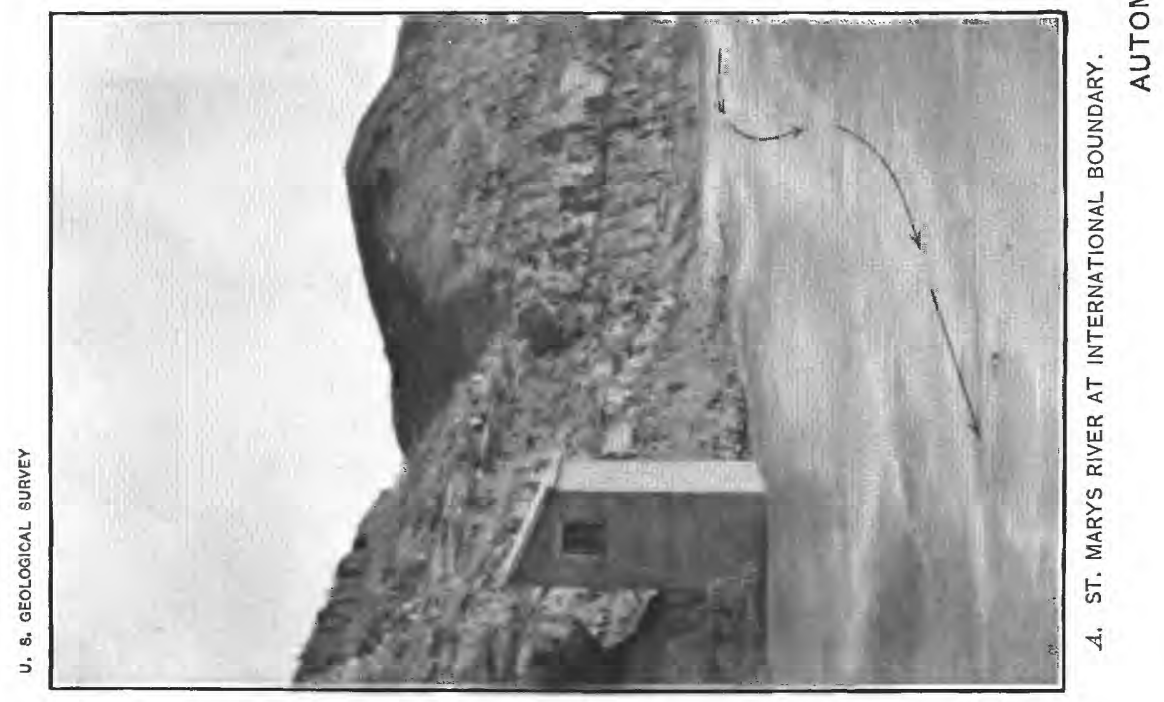


Item 6. Eight pieces waling strips on well.

7. 1,150 feet b. m. 1-inch T. G. \& S. or S. L. S. 6 by 8 inches by 12 feet sheathing (384 feet b. m.).

8. Braces, cleats, and sheathing in forms for footings.

9. Twenty-four $\frac{3}{4}$-inch bolts, 13 inches long, to bolt house walers together.

10. - telephone wire to tie well forms.

11. 10 pounds $8 \mathrm{~d}$. ( $2 \frac{1}{2}$-inch) wire nails.

12. 5 pounds $20 \mathrm{~d}$. (4-inch) wire nails.

13. 1 pound finishing nails for bevel pieces.

14. For each additional foot of depth of well increase the bill of 1-inch T. G. \& S. lumber by 40 feet $\mathrm{b}$. $\mathrm{m}$. and of dimension lumber according to depth.

In well:

SUMMARY OF LUMBER IN THE ABOVE BILI.

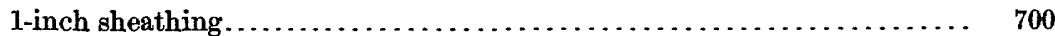

Dimension lumber...................................... 800

In shelter:

1 -inch sheathing........................................... 450

Dimension lumber................................ 075

3,025

Note.-This bill includes a reasonable allowance for cuts, undersized pieces, and mistakes, but the cutting scheme shown in the table should be followed carefully.

\section{BENCH MARKS.}

Too much care can not be taken to insure the permanence of the relation between the zero of the gage and the station bench marks.

Two independent bench marks at each station are desirable. At bridge stations at least one bench mark should be apart from the structure. A track spike with the front edge of the head upturned, driven into a tree, makes a useful bench mark. In a locality without timber the Water Resources bench mark (Pl. XXI, $A$, p. 37) may be used. To set it dig a small hole well below frost line with a posthole digger. Fill the hole with concrete and into this set the benchmark tablet. Always place the tablet with the axis of the stem vertical, so that the cross marking the elevation is actually the highest point of the bench mark.

Avoid placing bench marks on new or unstable structures. Wherever possible place the bench mark so that the gage may be reached in one set up.

\section{STRUCTURES USED IN MAKING DISCHARGE MEASURE- MENTS.}

\section{ESSENTIAL PARTS.}

A structure to support the engineer while measuring velocity and depth, on a stream that is too large to permit making measurements by wading, is necessary at current-meter stations. Such a structure may be (1) a cable for carrying a car, or (2) an existing or specially constructed bridge, or (3) a boat held in position by a cable or guy line. 
The equipment and appurtenances for a cable station consist of the cable and its accessories, the supports and anchorages for sustaining it, and a car for carrying the observer.

\section{CABLE EQUIPMENT.}

\section{SUPPORTS.}

Standard designs for A frame supports from 8 to 20 feet in height are shown in Plates XXV, XXVI, XXVII, and XXVIII. Plate XXIX, $A$, shows a typical support in place. These standards represent the most approved type of construction. In Plate XXVI is shown another method of hanging the sheave which may be used where desired. A spacing block should be used either above or below the sheave.

In determining the height of frame consideration should be given the highest stage of water, the clearance required below the foot rest of the car, the distance between foot rest and car pulleys, and the loaded sag of the cable. The sizes of posts for frames of any height should be fixed by the requirements of the load, which varies with the length of span. A bill of material is given for three or more post sizes for each frame height illustrated.

In all designs the main posts should be framed with a 1 in 5 batter, the distance across the top of the frame should be three-fourths inch less than the length of the top plate, and the spread at the bottom should be as shown in the drawings. The inside dimensions of frames are fixed by the height of frame, the use of the larger sizes of posts increasing only the outside dimensions. The longer crosssectional dimension of the post should be placed parallel to the cable.

The frames should be supported on mud sills, concrete piers, or other foundations that will distribute the load satisfactorily.

When concrete or other piers are used, provision should be made for fastening the frames to the piers. Such fastening may be accomplished by pairs of $\frac{3}{4}$-inch bolts set into the concrete 1 foot inside the posts, the bolts of each pair being spaced far enough apart to allow the sill $A$ to pass between them. An iron strap $\frac{1}{2}$ inch by 2 inches, bored to receive the bolts, should be placed on the sill and screwed down to the bolts to hold it in place.

To prevent the A frame from falling forward, a backstay of proper size should be carried through a turnbuckle to the anchorage. The backstay may be attached either to the eyebolt carrying the sheave or to a $U$ bolt of 2 -inch spread and sufficient length to pierce the posts 3 inches below the top plate. A Crosby clip is placed on the cable just back of the sheave to prevent the frame from falling backward.

A ladder for gaining access to the cable car is made by using iron telephone steps in one of the posts $B$, as shown in Plate XXVI. 


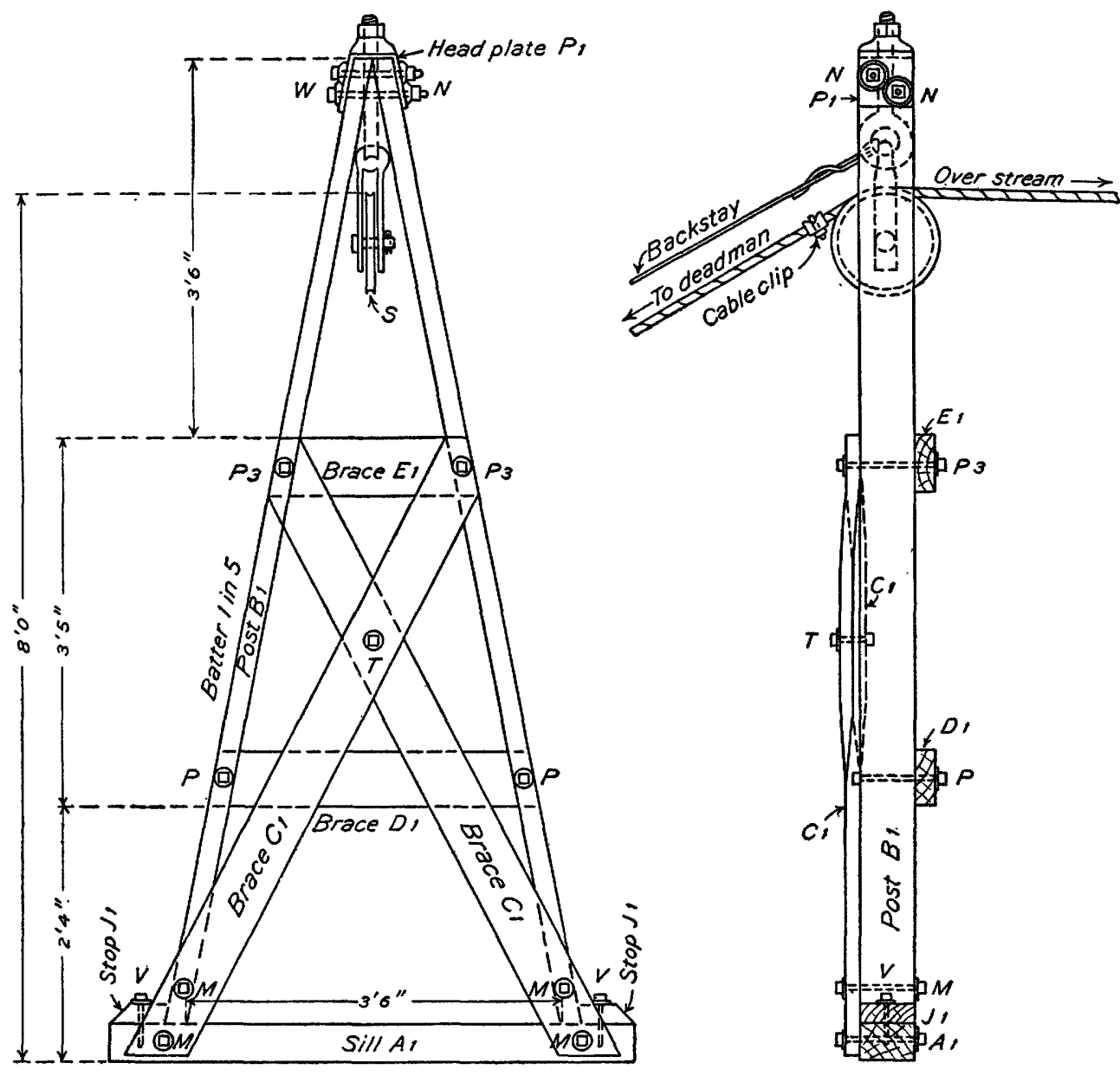

PLANS OF 8-FOOT "A" FRAME.

Bill of material given in Table 19, page 44. 

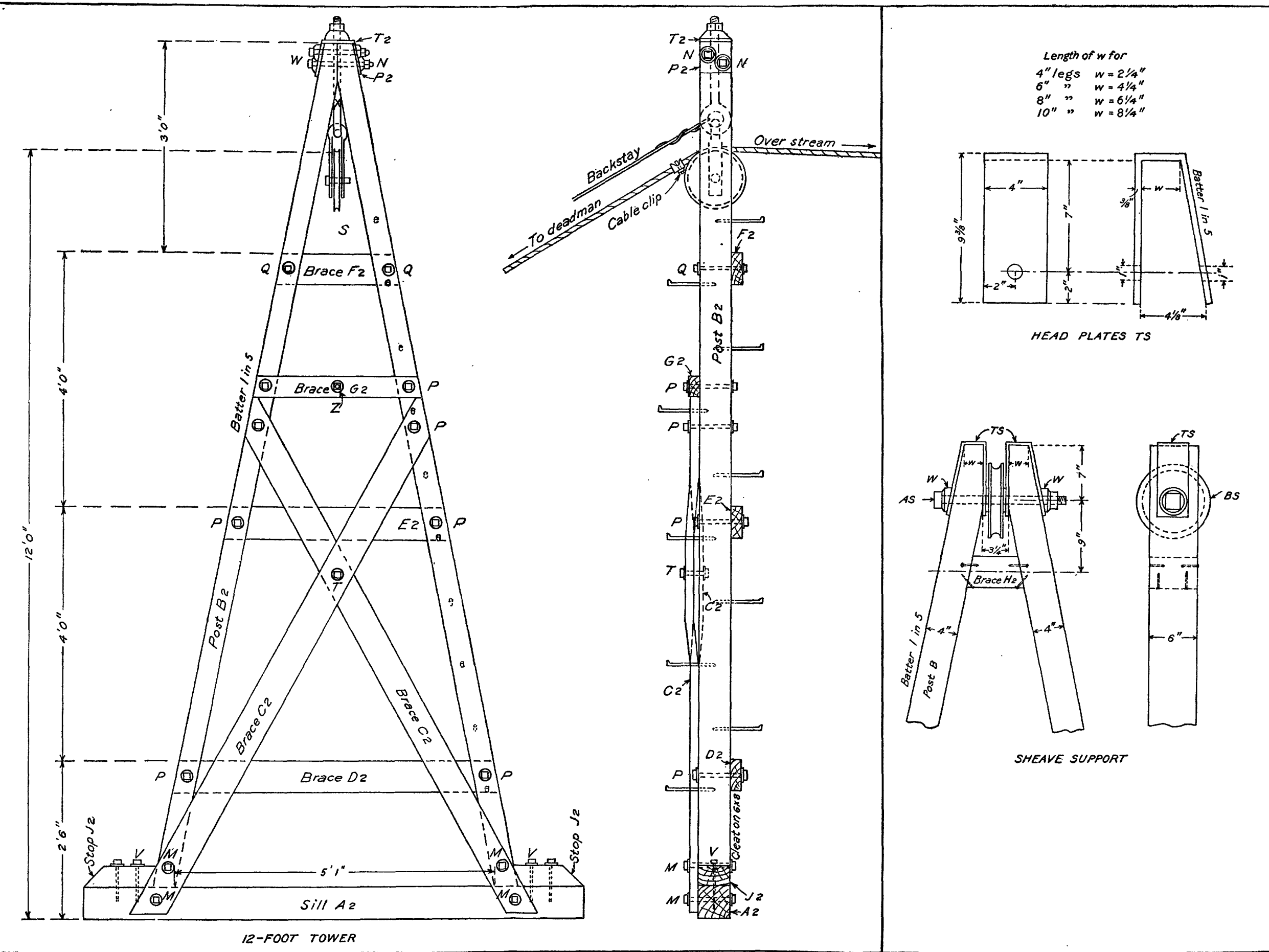

PLANS OF 12-FOOT "A" FRAME.

Bill of material given in Table 20, page 45 . 


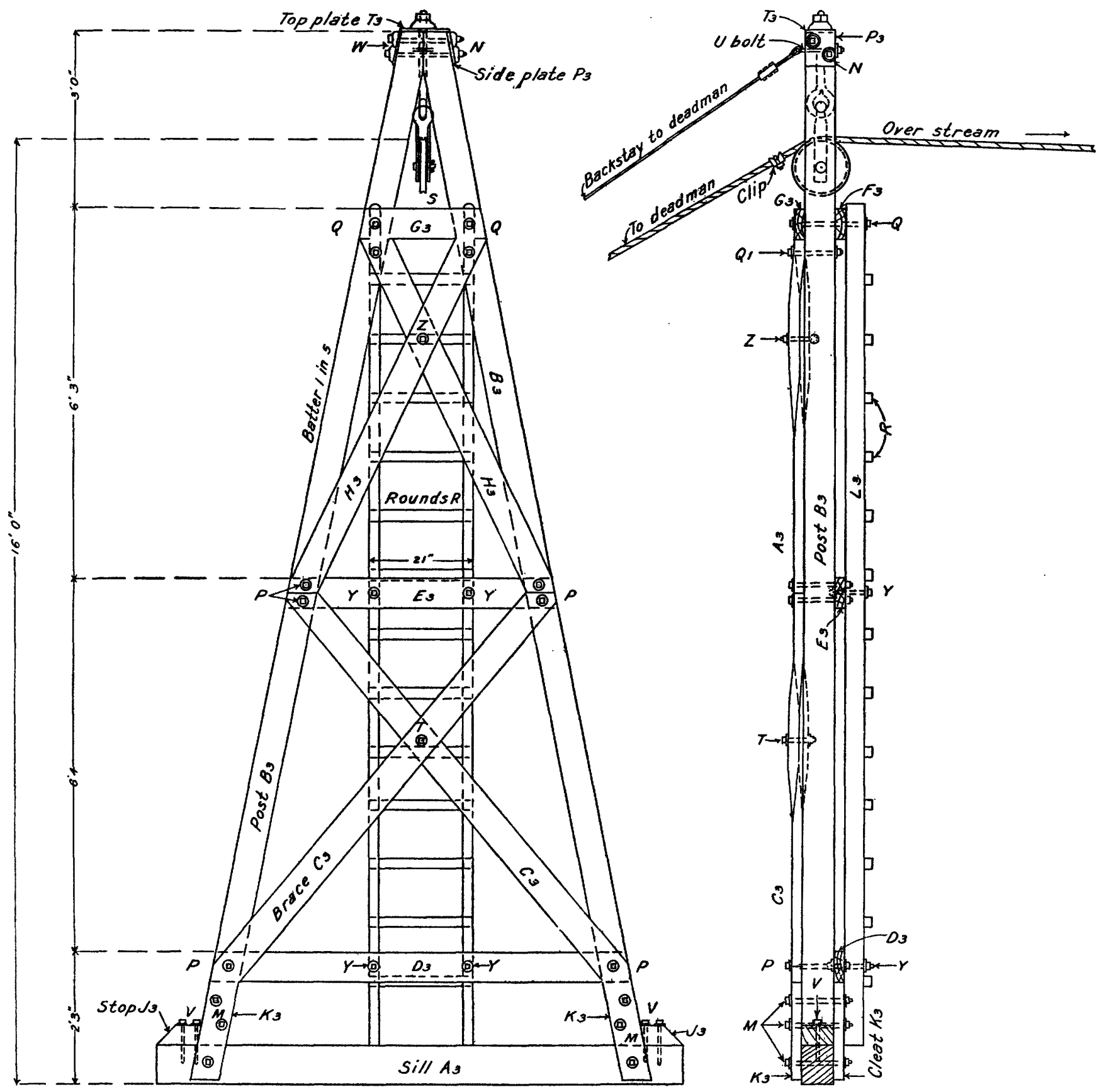

STANDARO 16' A FRAME 


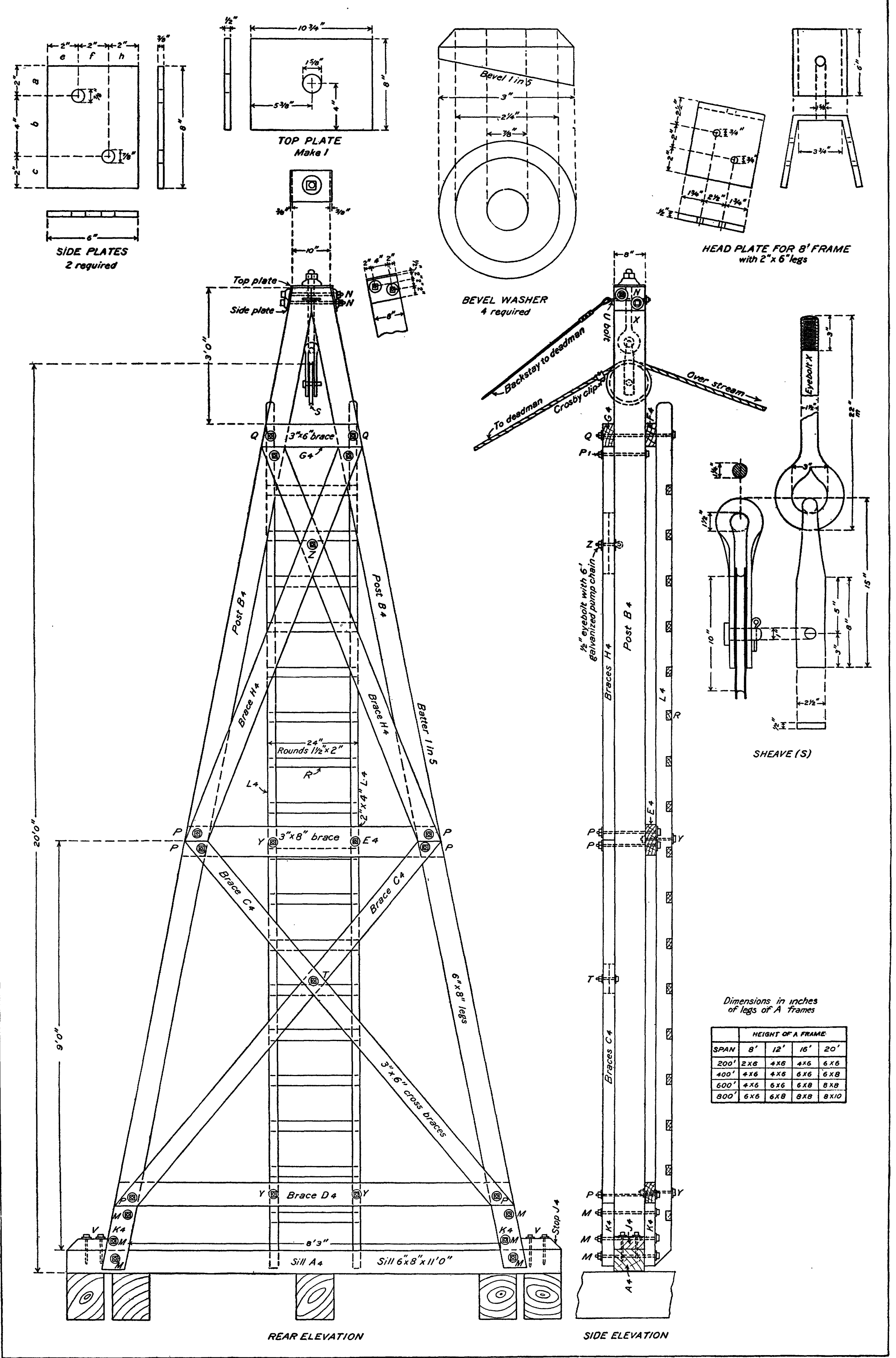


Otherwise a wooden ladder may be used, as shown in Plate XXVIII, the rounds of the ladder being spiked to the poles, or gained in and fastened with a $\frac{1}{4}$ by 4 inch carriage bolt, with a washer on the inside.

All timber used in the construction of the frames should be the best of its kind, thoroughly seasoned, and free from large or unsound knots, sap, shakes, wanes, dry rot, or other imperfections impairing its strength, durability, or appearance. All A frames must be given two coats of gray paint immediately after construction.

All top plates, as shown in Plate XXVIII, should be one-half inch thick and should have a 15 -inch hole through the center. All side plates should be three-eighths of an inch thick. Side plates for 8-foot frames with 2 by 6 inch posts should have $\frac{3}{4}$-inch holes; all other side plates should have $\frac{7}{8}$-inch holes. The length and breadth of top and side plates, length of head bolts, and spacing of holes in side plates are shown in the tables following.

TABLE 17.-Dimensions of top and side plates and bolts.

\begin{tabular}{|c|c|c|c|c|c|}
\hline \multirow{2}{*}{ Height of A frame. } & \multirow{2}{*}{$\begin{array}{l}\text { Size of } \\
\text { posts. } \\
\quad 1\end{array}$} & \multirow{2}{*}{$\begin{array}{l}\text { Top } \\
\text { plate. }\end{array}$} & \multirow{2}{*}{$\begin{array}{l}\text { Side } \\
\text { plate. }\end{array}$} & \multicolumn{2}{|c|}{$\begin{array}{l}\text { Length of } \frac{3}{4} \text {-inch } \\
\text { head bolts. }\end{array}$} \\
\hline & & & & Upper. & Lower. \\
\hline $\begin{array}{l}8 \text { feet }(\mathrm{Pl} . \mathrm{XXV}) \ldots \ldots \\
12 \text { feet (P1. XXVI) } \ldots \ldots \ldots \\
16 \text { feet (Pl. XXVII) } \ldots \ldots \\
20 \text { feet (Pl. XXVIII) } \ldots \ldots\end{array}$ & 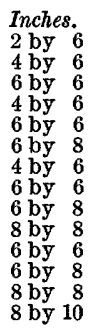 & \begin{tabular}{|} 
Inches. \\
(b) \\
6 by 6 \\
6 by $10 \frac{3}{4}$ \\
6 by 6 \\
6 by $10^{3}$ \\
8 by $10^{3}$ \\
6 by 6 \\
6 by $10 \frac{3}{4}$ \\
8 by $10 \frac{3}{4}$ \\
8 by 15 \\
6 by $10^{3}$ \\
8 by $10^{3}$ \\
8 by 15 \\
10 by 15
\end{tabular} & $\begin{array}{c}\text { Inches. } \\
(b) \\
6 \text { by } \\
6 \text { by } \\
6 \text { by } \\
6 \text { by } \\
6 \text { by } \\
6 \text { by } \\
6 \text { by } \\
6 \text { by } \\
6 \text { by } \\
6 \text { by } \\
6 \text { by } \\
6 \text { by } 8 \\
6 \text { by } 10\end{array}$ & $\begin{array}{r}\text { Inches. } \\
\text { (b) } \\
10 \\
15 \\
10 \\
15 \\
15 \\
15 \\
10 \\
15 \\
15 \\
19 \\
15 \\
15 \\
19 \\
19\end{array}$ & $\begin{array}{r}\text { Inches. } \\
(b) \\
11 \\
16 \\
11 \\
16 \\
16 \\
11 \\
16 \\
16 \\
20 \\
16 \\
16 \\
20 \\
20\end{array}$ \\
\hline
\end{tabular}

$a$ Distance across top of posts $B$ is three-fourths inch less than length of top plate. $b$ Special head plate with half-inch bolts.

TABLE 18.-Spacing of holes in side plates.

\begin{tabular}{|c|c|c|c|c|c|c|}
\hline \multirow{2}{*}{ Side plates for posts. } & \multicolumn{6}{|c|}{ Dimensions. } \\
\hline & a. & b. & c. & e. & f. & h. \\
\hline 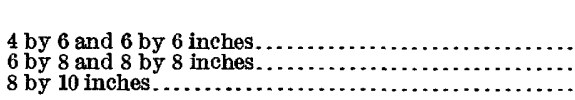 & $\begin{array}{c}\text { Inches. } \\
2 \\
2 \\
2 \frac{1}{\mathrm{~g}}\end{array}$ & \begin{tabular}{|c|} 
Inches. \\
2 \\
4 \\
$5 \frac{3}{4}$
\end{tabular} & \begin{tabular}{|c} 
Inches. \\
2 \\
2 \\
$2 \frac{1}{\mathrm{~g}}$
\end{tabular} & \begin{tabular}{|r|} 
Inches. \\
$1 \frac{3}{4}$ \\
2 \\
3
\end{tabular} & \begin{tabular}{|r|} 
Inches. \\
$2 \frac{1}{2}$ \\
2 \\
0
\end{tabular} & $\begin{array}{r}\text { Inches. } \\
\mathbf{1}^{\frac{3}{4}} \\
2 \\
3\end{array}$ \\
\hline
\end{tabular}


The length $m$ of eyebolt $X$ (Pl. XXVIII), which is furnished with the sheave $S$, should be 22 inches in all cases, except for the 8-foot frame with 2 by 6 inch posts, in which the dimension $m$ should be 18 inches. A thread 3 inches long should be cut on eyebolts. A nut and ogee washer should be furnished with the eyebolt.

The cable should always be carried on a movable support, preferably a sheave of fairly large diameter, and not on a cradle of either wood or metal.

The block which carries the cable is a very important detail of the support. The standard block and sheave have been designed to carry the maximum stress shown in Table 25 (p. 51). It should be made up of a 10-inch sheave of proper size for the cable, a 1-inch pin, and a strap, made from round iron flattened, of the dimensions shown on the drawing.

The arrangement of the sheave for carrying the cable shown in Plate XXVI may be substituted for the block when desired. It consists of two pieces, $T S$, of 4 by $\frac{3}{8}$-inch flat steel, bent to fit the tops of the posts $B$, and long enough to take the two 1-inch holes for the 1-inch bolt $A S$. Bevel washers $W$ are used against the post. The dimension of the top of post $B$ is given in Table 17 .

TABLE 19.-Bill of material for 8-foot frames.

[Lettered items refer to Plates XXV, XXVI, XXVII, and XXVIII.]

\begin{tabular}{|c|c|c|c|c|}
\hline Items. & $\begin{array}{l}\text { Num- } \\
\text { ber of } \\
\text { pieces. }\end{array}$ & 2 by 6 inch posts. & 4 by 6 inch posts. & 6 by 6 mch posts. \\
\hline 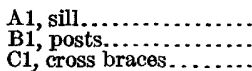 & $\begin{array}{l}1 \\
2 \\
2\end{array}$ & $\begin{array}{l}4 \text { by } 6 \text { inches by } 5 \text { feet. } \\
2 \text { by } 6 \text { inches by } 9 \text { feet. } \\
11 \text { by } 6 \text { inches by } 6\end{array}$ & $\begin{array}{l}6 \text { by } 6 \text { inches by } 5 \text { feet. } \\
4 \text { by } 6 \text { inches by } 9 \text { feet. }\end{array}$ & $\begin{array}{l}6 \text { by } 6 \text { mches by } 5 \text { feet. } \\
6 \text { by } 6 \text { mches by } 9 \text { feet. } \\
2 \text { by } 6 \text { mches by } 6\end{array}$ \\
\hline D1, brace. & 1 & 2 by 6 inches by 3 feet & $\begin{array}{l}\text { feet } 6 \text { inches. } \\
2 \text { by } 6 \text { inches by } 3 \text { feet }\end{array}$ & $\begin{array}{l}6 \text { mches. } \\
2 \text { by } 6 \text { inches by } 3 \text { feet }\end{array}$ \\
\hline 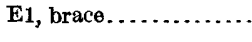 & 1 & 2 by 6 inches by 2 feet. & 2 by 6 mohes by 2 feet & 2 by 6 inches by 2 foet \\
\hline 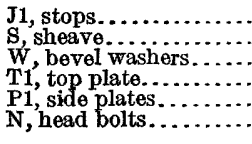 & $\begin{array}{c}2 \\
1 \text { sheav } \\
4 \\
1 \\
2 \\
1 \\
1\end{array}$ & 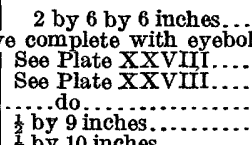 & 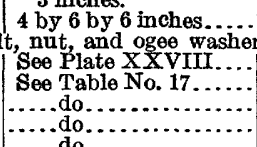 & $\begin{array}{l}4 \text { by } 6 \text { by } 6 \text { inches. } \\
\text { as per Plate XXVII. } \\
\text { See Plate XXVIII. } \\
\text { See Table } 17 . \\
\text { Do. } \\
\text { Do. }\end{array}$ \\
\hline $\begin{array}{l}\text { M, sill bolts.......... } \\
\text { P, post bolts....... } \\
\text { P3, post bolts ...... } \\
\text { V, lag serews...... } \\
\text { T, crossing boitt.... } \\
\text { Gray mixed paint.. }\end{array}$ & $\begin{array}{rr}a & 1 \\
a & 4 \\
a & 2 \\
a & 2 \\
a & 2 \\
& 1\end{array}$ & $\begin{array}{l}\frac{1}{2} \text { by } 10 \text { inches.. } \\
\frac{1}{2} \text { by } 8 \frac{1}{2} \text { inches.. } \\
\text { i. do do........ } \\
\frac{1}{2} \text { by } 10 \frac{1}{2} \text { inches. } \\
\frac{1}{2} \text { by } 5 \text { inches... } \\
\frac{1}{2} \text { by } 4 \text { inches... } \\
\frac{1}{2} \text { gallon......... }\end{array}$ & \begin{tabular}{l}
$\frac{1}{2}$ by $8 \frac{1}{2}$ inches... \\
\hdashline$\frac{1}{2}$ by $10 . . . . . . . . .$. \\
$\frac{1}{2}$ by 7 inches.. \\
$\frac{1}{2}$ by 4 inches.... \\
1 gallon......... \\
1 gallo.
\end{tabular} & $\begin{array}{l}\text { Do. } \\
\frac{3}{4} \text { by } 8 \frac{1}{2} \text { inches. } \\
6 \text { bolts } \frac{3}{3} \text { by } 8 \text { is mches. } \\
6 \text { bolts } \frac{1}{4} \text { by } 10 \frac{1}{2} \text { inches. } \\
\frac{1}{2} \text { by } 7 \text { inches. } \\
\frac{1}{2} \text { by } 4 \frac{1}{2} \text { mches. } \\
1 \text { gallon. }\end{array}$ \\
\hline
\end{tabular}

- With 2 flat washers each. One washer only for lag screws. 

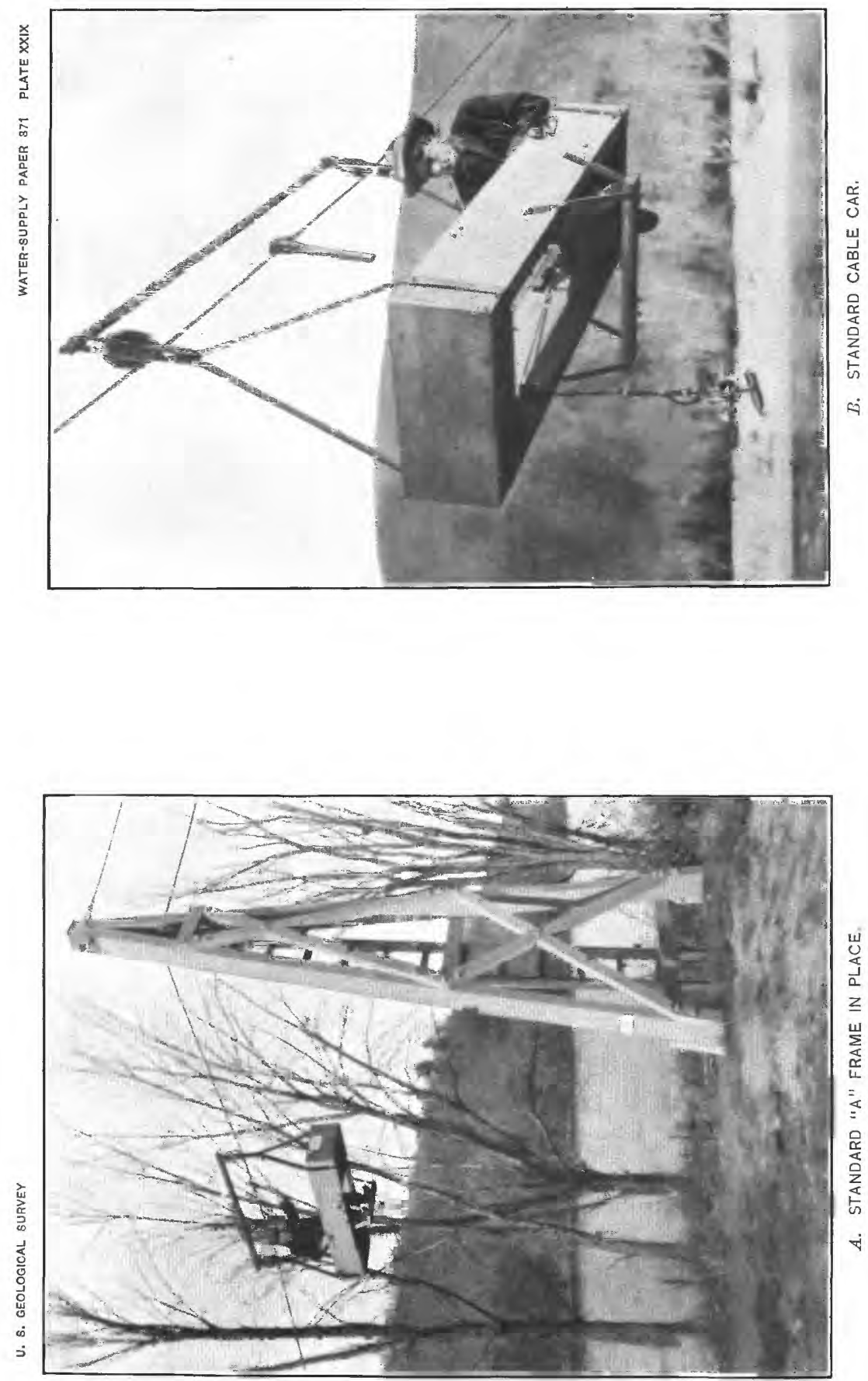
TABLE 20.-Bill of material for 12-foot frames.

\begin{tabular}{|c|c|c|c|c|}
\hline Itoms. & $\begin{array}{l}\text { Num- } \\
\text { ber of } \\
\text { pieces. }\end{array}$ & 4 by 6 inch posts. & 6 by 6 inch posts. & 6 by 8 inch posts. \\
\hline 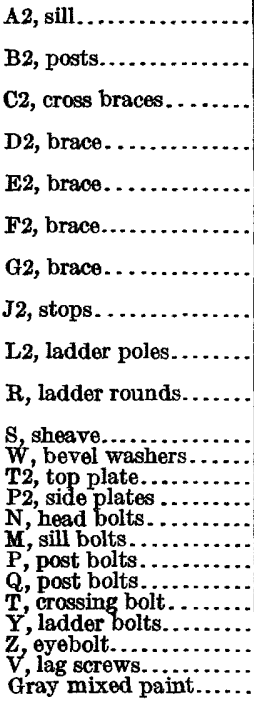 & $\begin{array}{r}1 \\
2 \\
1 \\
1 \\
1 \\
1 \\
2 \\
2 \\
8 \\
\text { sheave } \\
4 \\
1 \\
2 \\
a 2 \\
a 4 \\
a 8 \\
a 2 \\
a 1 \\
a 4 \\
a 1 \\
4 \\
\ldots \ldots\end{array}$ & 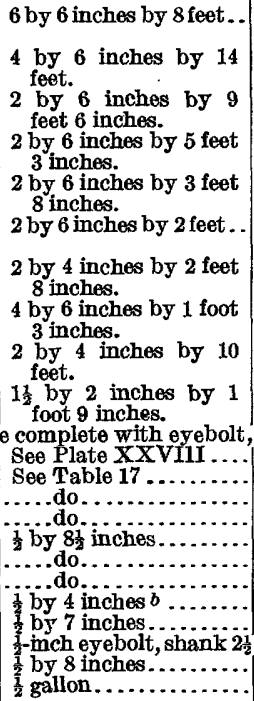 & 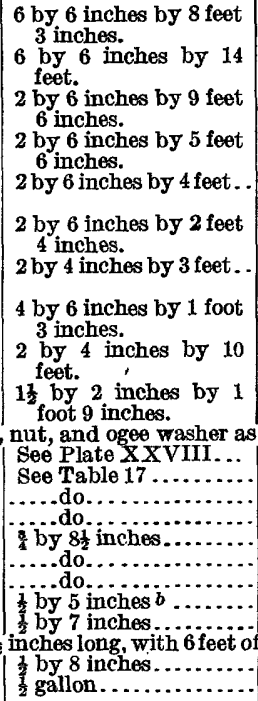 & $\begin{array}{l}6 \text { by } 8 \text { inches by } 8 \text { feet } \\
3 \text { inches. } \\
6 \text { by } 8 \text { inches by } 14 \\
\text { feet. } \\
2 \text { by } 6 \text { inches by } 9 \text { feet } \\
6 \text { inches. } \\
2 \text { by } 6 \text { inches by } 5 \text { feet } \\
6 \text { inches. } \\
2 \text { by } 6 \text { inches by } 4 \text { feet. } \\
2 \text { by } 6 \text { inches by } 2 \text { feet } \\
4 \text { inches. } \\
2 \text { by } 4 \text { inches by } 3 \text { feet. } \\
4 \text { by } 6 \text { inches by } 1 \text { foot } \\
3 \text { inches. } \\
2 \text { by } 4 \text { inches by } 10 \\
\text { feet. } \\
1 \frac{1}{2} \text { by } 2 \text { inches by } 1 \\
\text { foot } 9 \text { inches. } \\
\text { per Plate XXVIT. } \\
\text { See Plate XXV1I. } \\
\text { See Table } 17 . \\
\text { Do. } \\
\text { Do. } \\
\frac{3}{4} \text { by } 13 \text { inches. } \\
\frac{3}{4} \text { by } 11 \text { inches. } \\
\frac{3}{4} \text { by } 15 \text { inches. } \\
\frac{1}{2} \text { by } 5 \text { inches.b } \\
\frac{1}{2} \text { by } 7 \text { inches. } \\
\text { gaIvanized pump chain. } \\
\frac{1}{2} \text { by } 8 \text { inches. } \\
1 \text { gallon. }\end{array}$ \\
\hline
\end{tabular}

$a$ With 2 flat washers each. One washer only on lag screw.

$b$ This length when cross braces are halved; 2 inches longer when they overlap.

If iror telephone steps are used omit all ladder items and make post bolts $Q 4$ inches shorter.

TABLE 21.-Bill of material for 16-foot frames.

\begin{tabular}{|c|c|c|c|}
\hline Items. & $\begin{array}{l}\text { Number } \\
\text { of pieces. }\end{array}$ & 4 by 6 inch posts. & 6 by 6 inch posts. \\
\hline 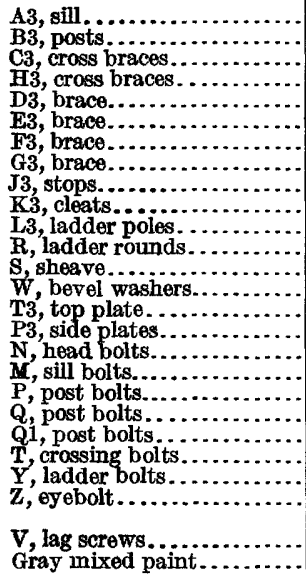 & \begin{tabular}{|r|r}
1 \\
2 \\
2 \\
2 \\
1 \\
1 \\
1 \\
1 \\
2 \\
4 \\
2 \\
13 \\
1 sheave c \\
4 \\
1 \\
2 \\
2 \\
$a 6$ \\
$a 6$ \\
$a 2$ \\
$a 2$ \\
1 \\
4 \\
1 \\
$a 4$
\end{tabular} & 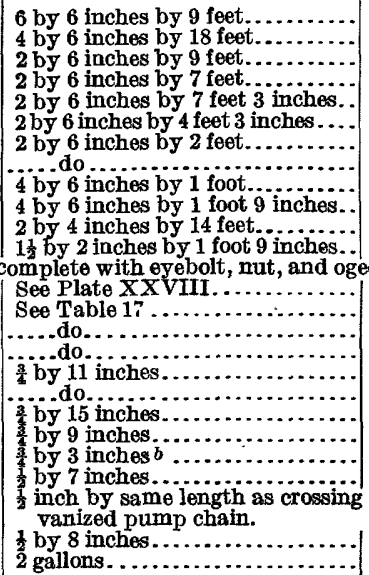 & $\begin{array}{l}6 \text { by } 8 \text { inches by } 9 \text { feet. } \\
6 \text { by } 6 \text { inches by } 18 \text { feet. } \\
2 \text { by } 6 \text { inches by } 9 \text { feet. } \\
2 \text { by } 6 \text { inches by } 7 \text { feet. } \\
2 \text { by } 6 \text { inches by } 7 \text { feet } 3 \text { inches. } \\
2 \text { by } 6 \text { inches by } 4 \text { feet } 8 \text { inches. } \\
2 \text { by } 6 \text { inches by } 2 \text { feet } 3 \text { inches. } \\
\text { Do. } \\
4 \text { by } 6 \text { inches by } 1 \text { foot. } \\
4 \text { by } 6 \text { inches by } 1 \text { foot } 9 \text { inches. } \\
2 \text { by } 4 \text { inches by } 14 \text { feet. } \\
1 \frac{1}{2} \text { by } 2 \text { inches by } 1 \text { foot } 9 \text { inches. } \\
\text { ee washer, as per Plate XXVIll. } \\
\text { See Plate XX XIII. } \\
\text { See Table } 17 . \\
\text { Do. } \\
\text { Do. } \\
\frac{3 \text { by } 11 \text { inches. }}{\text { Do. }} \\
\frac{3}{3} \text { by } 15 \text { inches. } \\
\frac{3}{4} \text { by } 9 \text { inches. } \\
\frac{3}{4} \text { by } 3 \text { inches. } \\
\frac{1}{2} \text { by } 7 \text { inches. } \\
\text { bolt, with nut and } 6 \text { foet of gal- } \\
\frac{1}{2} \text { by } 8 \text { inches. } \\
2 \text { gallons. }\end{array}$ \\
\hline
\end{tabular}

a With posts over 6 by 6 inches cross section use ogee washers. The additional thickness of ogee washers is allowed for in billing the bolt. For 6 by 6 inches or less use flat washers, 2 on each bolt and 1 on each lag serew.

This length when cross braces are halved; 2 inches longer when they overlap.

If iron telephone stops are used omit all ladder items and make post bolts $Q 4$ inches shorter. 
TABLE 21.-Bill of material for 16-foot frames-Continued.

\begin{tabular}{|c|c|c|c|}
\hline Items. & $\begin{array}{l}\text { Number } \\
\text { of pieces. }\end{array}$ & 6 by 8 inch posts. & 8 by 8 inch posts. \\
\hline 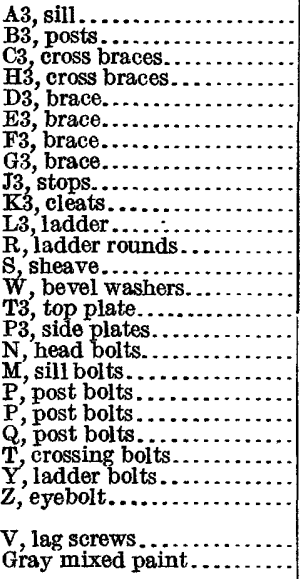 & $\begin{array}{rr}1 \\
2 \\
2 \\
2 \\
1 \\
1 \\
1 \\
1 \\
2 \\
4 \\
2 \\
13\end{array}$ & 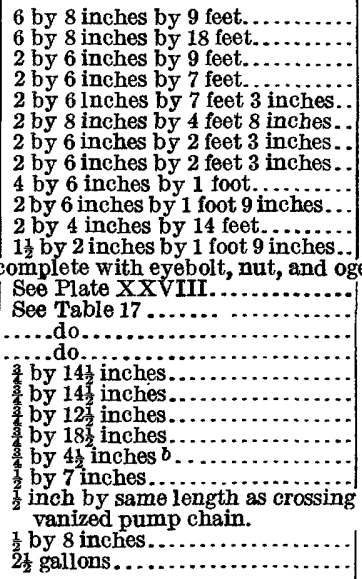 & $\begin{array}{l}8 \text { by } 10 \text { inches by } 9 \text { feet } 3 \text { inches. } \\
8 \text { by } 8 \text { inches by } 18 \text { feet. } \\
3 \text { by } 6 \text { inches by } 9 \text { feet. } \\
3 \text { by } 6 \text { inches by } 7 \text { feet. } \\
3 \text { by } 8 \text { inches by } 7 \text { feet } 6 \text { inches. } \\
3 \text { by } 8 \text { inches by } 4 \text { feet } 10 \text { inches. } \\
3 \text { by } 6 \text { inches by } 2 \text { feet } 6 \text { inches. } \\
3 \text { by } 6 \text { inches by } 2 \text { feet } 6 \text { inches. } \\
4 \text { by } 6 \text { inches by } 1 \text { foot. } \\
3 \text { by } 6 \text { inches by } 1 \text { foot } 9 \text { inches. } \\
2 \text { by } 4 \text { inches by } 14 \text { feet. } \\
1 \frac{1}{2} \text { by } 2 \text { inches by } 1 \text { foot } 9 \text { inches. } \\
\text { washer as per Plate XXVIII. } \\
\text { See Plate XXVIII. } \\
\text { See Table } 17 . \\
\text { Do. } \\
\text { Do. } \\
\frac{3}{4} \text { by } 16 \frac{1}{2} \text { inches. } \\
\frac{3}{3} \text { by } 16 \text { inches. } \\
\frac{3}{4} \text { by } 13 \frac{1}{2} \text { inches. } \\
\frac{3}{4} \text { by } 20 \frac{1}{2} \text { inches. } \\
\frac{3}{4} \text { by } 5 \frac{1}{2} \text { inches. } b \\
\frac{1}{2} \text { by } 8 \text { inches. } \\
\text { bolt, with nut and } 6 \text { feet of gal- } \\
\frac{1}{2} \text { by } 8 \text { inches. } \\
2 \frac{1}{2} \text { gallons. }\end{array}$ \\
\hline
\end{tabular}

$a$ With posts over 6 by 6 inches cross section use ogee washers. The additional thickness of ogeo washers is allowed for in billing the bolt. For 6 by 6 inches or less use flat washers, 2 on each bolt and 1 on each lag screw.

$b$ This length when cross braces are halved; 2 inches longer when they overlap.

If iron telephone steps are used omit all ladder items and make post bolts $Q 4$ inches shorter.

TABLE 22.-Bill of material for 20-foot frames.

\begin{tabular}{|c|c|c|c|}
\hline Items. & $\begin{array}{l}\text { Number } \\
\text { of pieces. }\end{array}$ & 6 by 6 inch posts. & 6 by 8 inch posts. \\
\hline 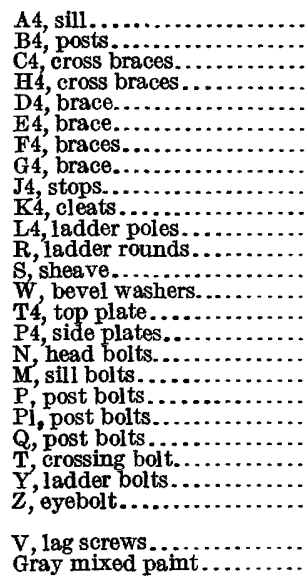 & $\begin{array}{rr}1 \\
2 \\
2 \\
2 \\
1 \\
1 \\
1 \\
1 \\
2 \\
4 \\
2 \\
17 \\
1 \text { sheave } \\
4 \\
1 \\
2 \\
a 2 \\
a \\
a \\
a & 6 \\
a & 2 \\
a & 2 \\
a & 1 \\
4 \\
a & 1 \\
a & 4 \\
a . . . .\end{array}$ & 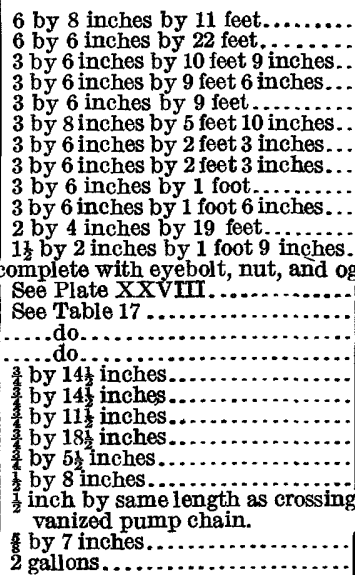 & 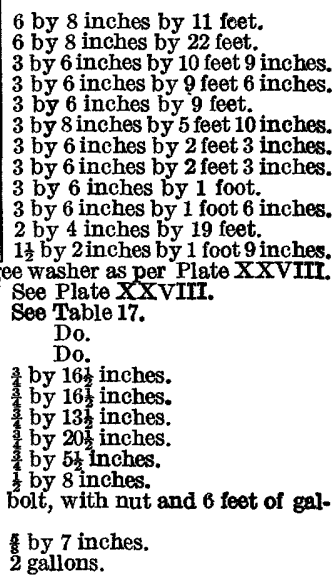 \\
\hline
\end{tabular}

a On 20-foot frames use ogee washers. These are approximately three-fourths inch thick, which additional thickness is allowed for in billing the bolt. Use 1 flat washer on each lag screw and 2 on ladder bolts.

If iron telephone steps are used omit all ladder items and make post bolts $Q 4$ inches shorter. 


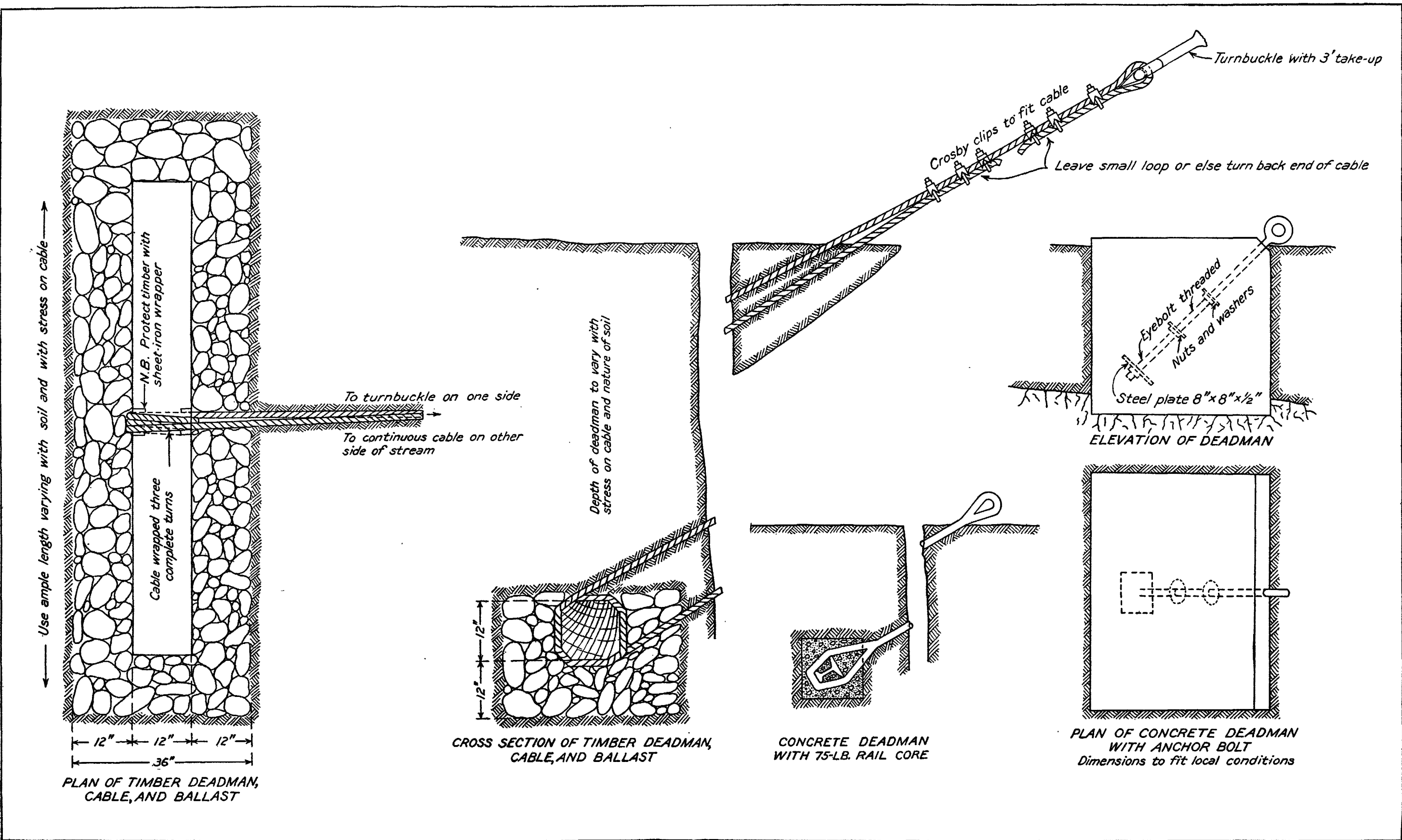


TABLE 22.-Bill of material for 20-foot frames-Continued.

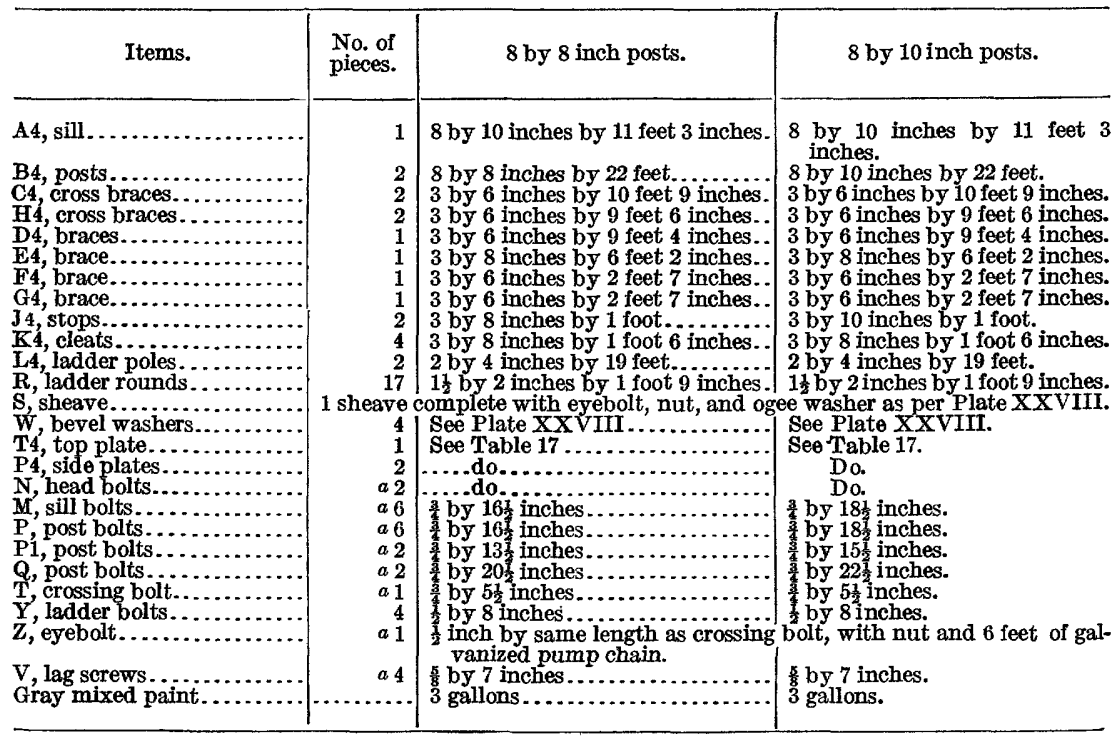

$a$ On 20-foot frames use ogee washers. These are approximately three-fourths inch thick, which additional thickness is allowed for in billing the bolt. Use 1 flat washer on each lag screw and 2 on ladder bolts.

If iron telephone stops are used omit all ladder items and make post bolts $Q 4$ inches shorter.

\section{ANCHORAGES.}

COMMON TYPES.

The most usual types of anchorages for cables are deadmen, trees, and rock ledges. Designs of timber and concrete deadmen are shown in Plate XXX. The anchorages should always be so placed that they may be readily inspected. A station record showing the type, construction features, and date of installation of anchorages should be kept. Timber deadmen should be thoroughly inspected at least once in four years to determine the condition of the timber.

DEADMEN.

The timber for deadmen should be carefully selected. Logs rather than dimension timber should be used. All timber should be sound, durable, and cleaned of all bark and foreign matter. Carbolineum or creosote should be used as a preservative; if neither is available, the timber may be charred.

No deadmen should be less than 12 inches in diameter nor less than 8 feet long. All deadmen should be so constructed as to provide a large factor of safety. The length of the stick and the depth to which it should be buried will depend on the stress on the cable and the nature of the soil. In ordinary loam, clay, or sand the depth should not be less than 6 feet. Additional bearing power may be given by inserting pieces of plank in front of the deadmen. The cable should 
ROCK LEDGES.

A rock ledge is in many places the only available anchorage. The ledge must be carefully examined before it is used, to uncover possible fissures or faults, the texture of the rock noted very carefully, and the thickness of the ledge measured if possible. If the rock proves durable and heavy enough, a hole should be drilled into it not less than 24 inches deep and 2 inches in diameter. The anchor bolt should be made of $1 \frac{1}{2}$-inch steel, with a split or expansion end provided with a steel wedge, and an eye with a ship-eye weld at the other end. The bolt should be sledged into the hole until the wedge has expanded the split as far as possible. The remaining space, out to the face of the ledge, should be filled with neat Portland cement grout and left to set for 48 hours before the load is put upon the bolt. Sulphur, sulphur and lead, Babbitt metal, or brimstone may be used for the filling. In many places these are preferred to cement.

A very secure fastening may be made on top of a ledge with a $U$ bolt, with corners bent square, made of $1 \frac{1}{2}$-inch round steel. The spread of the bolt should be 12 inches and the length of each leg 18 inches. The $U$ bolt, inverted, is placed into two holes drilled in line with the cable and fastened as described above for the eyebolt. The cable should be passed through the $U$ bolt and fastened with cable clips, a thimble being used to protect the cable. Three driftbolts can also be used by arranging them in a triangular position with the apex toward the river. The cable is then run through the three eyes and fastened by cable clips.

CABLES AND ACCESSORIES.

THE CABLE.

The cable should be composed of six strands, each strand containing seven wires around a hemp center. The material should be the best quality plow steel. The cable should be galvanized and should be one continuous piece, no splicing being allowed. As a rule the cable must be ordered from the factory, as few dealers carry galvanized plow-steel cable in stock.

Two sizes of cable are regarded as standard- $\frac{5}{8}$-inch cable for spans under 400 feet; $\frac{3}{4}$-inch cable for spans between 400 and 650 feet.

The proper loaded sag for each span must be determined from the sag diagram, Plate XXXI, in order not to exceed the standard working stress in the cable.

Tables 25, 26, and 27 show functions of other than standard sizes of cables. These, together with Plate XXXI, cover the range of ordinary requirements.

The calculations for cables are based upon the method published by J. C. Stevens in Engineering News, May 6, 1909. A working 


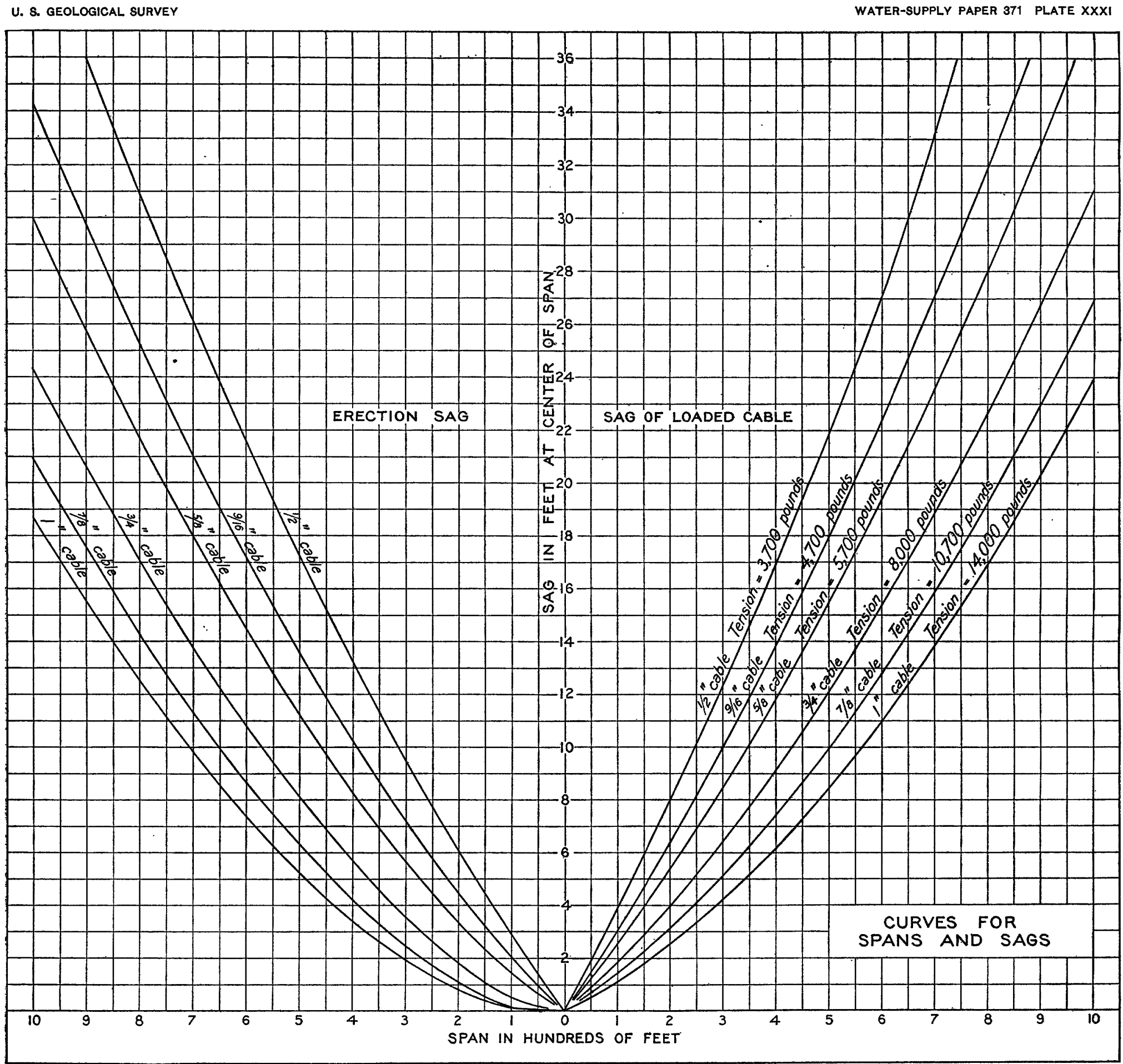

SAG DIAGRAM FOR CABLES. 
stress of one-sixth the ultimate strength, as published by manufacturers of cable, is used throughout. The tables present data for regular sizes of cables from half an inch to 1 inch and for spans from 100 to 1,000 feet, covering all ordinary requirements of stream-gaging work. For other conditions special designs should be made.

Table 25 shows, for specified spans, cable sizes and corresponding allowable working stresses and the "loaded sag" that will occur in various span lengths under the dead load of the weight of cable and an assumed concentrated load of 550 pounds, which represents the approximate weight of the car, meter equipment, and two observers.

Table 26 shows the "erection sag," or sag without concentrated load, of the cables listed in Table 27, and also shows the tension placed on each cable or the pull required in erecting it to the prescribed sag distance.

Plate XXXI shows graphically the information contained in Tables 25 and 26.

Table 27 shows for specified span lengths the diameter of the smallest cable that may properly be used and the corresponding sag.

TABLE 25.-Sag for loaded cables.

[Plow-steel cablo-6 strands of 7 wires each-concentrated load 550 pounds.]

\begin{tabular}{|c|c|c|c|c|c|c|}
\hline \multirow[b]{2}{*}{$\begin{array}{l}\text { Span in } \\
\text { feet. }\end{array}$} & \multicolumn{6}{|c|}{ Allowable working stress in pounds. } \\
\hline & $\begin{array}{c}\text { One-half } \\
\text { inch cable, } \\
3,700 .\end{array}$ & $\begin{array}{c}\text { Nine- } \\
\text { sixteenths } \\
\text { inch cable, } \\
4,700 .\end{array}$ & $\begin{array}{c}\text { Five- } \\
\text { ejghths } \\
\text { inch cable, } \\
5,700 .\end{array}$ & $\begin{array}{c}\text { Three- } \\
\text { fourths } \\
\text { inch cable, } \\
8,000 \text {. }\end{array}$ & $\begin{array}{c}\text { Seven- } \\
\text { eighths } \\
\text { inch cable, } \\
10,700 \text {. }\end{array}$ & $\begin{array}{c}\text { One-inch } \\
\text { cable, } \\
14,000 .\end{array}$ \\
\hline $\begin{array}{r}100 \\
200 \\
300 \\
400 \\
500 \\
600 \\
800 \\
1,000\end{array}$ & $\begin{array}{r}\text { Feet. } \\
3.85 \\
7.96 \\
12.33 \\
16.97 \\
21.88 \\
27.04 \\
38.16 \\
50.34\end{array}$ & $\begin{array}{r}\text { Feet. } \\
3.06 \\
6.38 \\
9.97 \\
13.83 \\
17.95 \\
22.34 \\
31.91 \\
42.55\end{array}$ & $\begin{array}{r}\text { Feet. } \\
2.55 \\
5.37 \\
8.46 \\
.11 .82 \\
15.46 \\
19.36 \\
28.00 \\
37.71\end{array}$ & $\begin{array}{r}\text { Feet. } \\
1.86 \\
3.99 \\
6.41 \\
9.10 \\
12.07 \\
15.32 \\
22.65 \\
31.09\end{array}$ & $\begin{array}{r}\text { Feet. } \\
1.43 \\
3.13 \\
5.12 \\
7.38 \\
9.93 \\
12.75 \\
19.25 \\
26.87\end{array}$ & $\begin{array}{r}\text { Feet. } \\
1.12 \\
2.53 \\
4.22 \\
6.18 \\
8.44 \\
10.97 \\
16.88 \\
23.92\end{array}$ \\
\hline
\end{tabular}


TABLE 26.-Erection sag (in feet) and tension in erecting cables.

[Plow-steel rope-6 strands of 7 wires each.]

\begin{tabular}{|r|r|r|r|r|r|}
\hline & \multicolumn{5}{|c|}{ Diameter of cable in inches. } \\
Span in \\
feet.
\end{tabular}

TABLE 27.-Smallest allowable cable, with corresponding sag for various spans.

\begin{tabular}{|c|c|c|c|}
\hline Span. & Cable. & $\begin{array}{l}\text { Loaded } \\
\text { sag. }\end{array}$ & $\begin{array}{l}\text { Erection } \\
\text { sag. }\end{array}$ \\
\hline 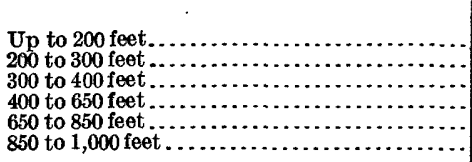 & 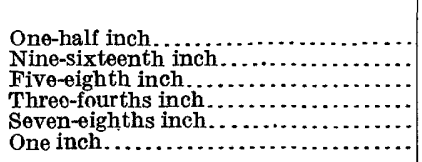 & $\begin{array}{l}\text { Feet. } \\
8 \\
10 \\
\quad 11.8 \\
17 \\
21.1 \\
24\end{array}$ & $\begin{aligned} \text { Feet. } \\
6 \\
7.2 \\
8.3 \\
12.2 \\
15.9 \\
18.7\end{aligned}$ \\
\hline
\end{tabular}

When selecting a cable for a given span, note first the smallest size that may be used, as specified in Table 27. Next find from Plate XXXI or Table 25 the loaded sag and estimate the necessary height of support. It should be noted that for a given span cables other than the smallest size allowable have less sag, so that where it is necessary, as for reducing the height of support, a cable of larger size than the minimum may be used.

\section{TURNBUCKLES.}

In order to adjust the cable to the proper sag, a turnbuckle is placed between the deadman and the support. It should be placed close to the ground, so that it may be easily operated.

With cables up to five-eighths inch use a standard 1-inch turnbuckle; with cables between five-eighths and 1 inch use a standard 
$1 \frac{1}{2}$-inch turnbuckle. A thimble of proper size is used in each eye of the turnbuckle.

The turnbuckles should be of standard manufacture, of round iron, eye and eye, galvanized, and have 36 -inch take-ups.

CIIPS.

Three cable clips are applied at each point where the cable is fastened. All clips must be the same size as the cable

\section{BACKSTAY.}

A backstay should be run from the top of the support to the anchorage and should be fastened with wire-rope clamps. It is desirable to insert a galvanized eye and eye turnbuckle with 6-inch take-up in the backstay.

For stations using $\frac{5}{8}$-inch cables use $\frac{1}{4}$-inch galvanized wire-strand backstay, with $\frac{1}{4}$-inch eye and eye turnbuckle; with stations using up to 1-inch cables use galvanized wire-strand backstay half an inch in diameter, with $\frac{1}{2}$-inch galvanized eye and eye turnbuckle. The galvanized wire strand is composed of seven steel wires twisted into a single strand and is commonly used as a guy rope by electric-light companies.

\section{IIST OF MATERIALS.}

For each cable station the materials shown in the following table are required:

TABLE 28.-Bill of material for cable installation.

_- feet galvanized plow steel cable, —_ diameter.

Fourteen cable clips, same size as cable, three at each anchorage, three at each end of turnbuckle, one behind each sheave $S$ of support.

- feet galvanized wire strand, _- diameter.

Eight wire-rope clamps, same diameter as wire strand, one at each anchorage, one at each support, one at each end of turnbuckle.

One galvanized turnbuckle, eye and eye, proper size for cable used. .

Two oval wire-rope thimbles, galvanized, same size as cable.

Two galvanized turnbuckles, eye and eye, same size as wire strand.

CARS.

The dimensions of the standard car (PI. XXIX, B) are shown in full detail in Plate XXXII, and a complete list of the material for its construction is given in Table 29. The frame and sides of the car may be inade of any suitable lumber, the pieces preferably being fastened together with screws. The appearance of the finished car is shown in Plate XXIX, $B$.

The frame of the car should be given two coats of good paint, one before and one after assembling. A high-grade gray paint may be made by mixing white lead and boiled linseed oil and adding 1 part 
of mixed coach black to 8 parts of mixed lead and oil. Carbolineum (applied hot) instead of paint makes a very satisfactory finish.

The marker $T$, which may be made of a piece of lath of similar wood, is attached to the spacing bar $G$ exactly 5 feet from a point over the side sheave $K$, so that in connection with markings on the cable the measuring section may be readily located.

A scale of $\frac{3}{4}$-inch by 2 -inch material, long enough to reach between the seats and properly graduated, should be fastened to the top of the frame $A$ as an aid in sounding. A suitable cleat or cable snub should be provided to hold the meter in a fixed position.

A shelter over the car for the protection of the hydrographer against rain has been used in Hawaii. This shelter is made of a piece of rubberoid roofing resting on the bar $G$, to which it is tacked and spread beyond the sides of the car by two wooden spreaders of light material nailed to the separators $H$.

A notebook rest or table may be attached to the top and outside of the right-hand side board of the car, as used, at a convenient distance in front of the main hanger. It should be attached by means of a pair of 3-inch strap hinges and two screw hooks and eyes, which hold it in position for use. When not in use, the hook is released and the table folds down over the outside of the car. A steel paper clip screwed to the top of the table holds the notebook while the measurement is being made.

All ironwork on the car must be galvanized.

TABLE 29.-Bill of material for standard cable car.

[Lettered items refer to Plate XXXII.]

LUMBER.

Item 1 . One piece 2 by 4 inches by 18 feet ( 12 feet b. m.) S $4 \mathrm{~S}$, from which cutTwo pieces $A$, sides of bed frame, 6 feet long.

Two pieces $B$, ends of bed frame, 1 foot 7 inches long.

One piece $F$, foot rest, 2 feet 2 inches long.

2. Two pieces 1 by 10 inches by 10 feet ( 17 feet b. $\mathrm{m}$.), S $4 \mathrm{~S}$, from which cut-

Two pieces $C$, sides of car, 6 feet long.

Two pieces $D$, ends of car, 2 feet long.

Two pieces $E 1$, seats of car, 1 foot 10 inches long.

3. One piece 1 by 8 inches by 16 feet (11 feet b. m.), S $4 \mathrm{~S}$, from which cut-

Two pieces $E 2$, bottom of tool box, 2 feet long.

Two pieces $E 3$, seats, 1 foot 10 inches long.

Two pieces $E 4$, bottom of tool box, 2 feet long.

Two pieces $E 5$, front of tool box, 1 foot 7 inches long.

4. One piece 2 by 2 inches (exact) by 8 feet 3 inches, $\mathrm{S} 4 \mathrm{~S}$, from which cut-

One piece $G$, top spacing bar, 7 feet 7 inches long.

Two pieces $H$, spacing blocks, 4 inches long.

5. One-half gallon of gray mixed paint.

HARDWARE.

Item 6. Two cast-iron roller-bearing, spoked sheaves $I$, 8-inch diameter for $1 \frac{1}{8}$-inch cable, with pins $M$, of proper length and diameter, cotter pin in one end and two washers for each pin, as per detail. 


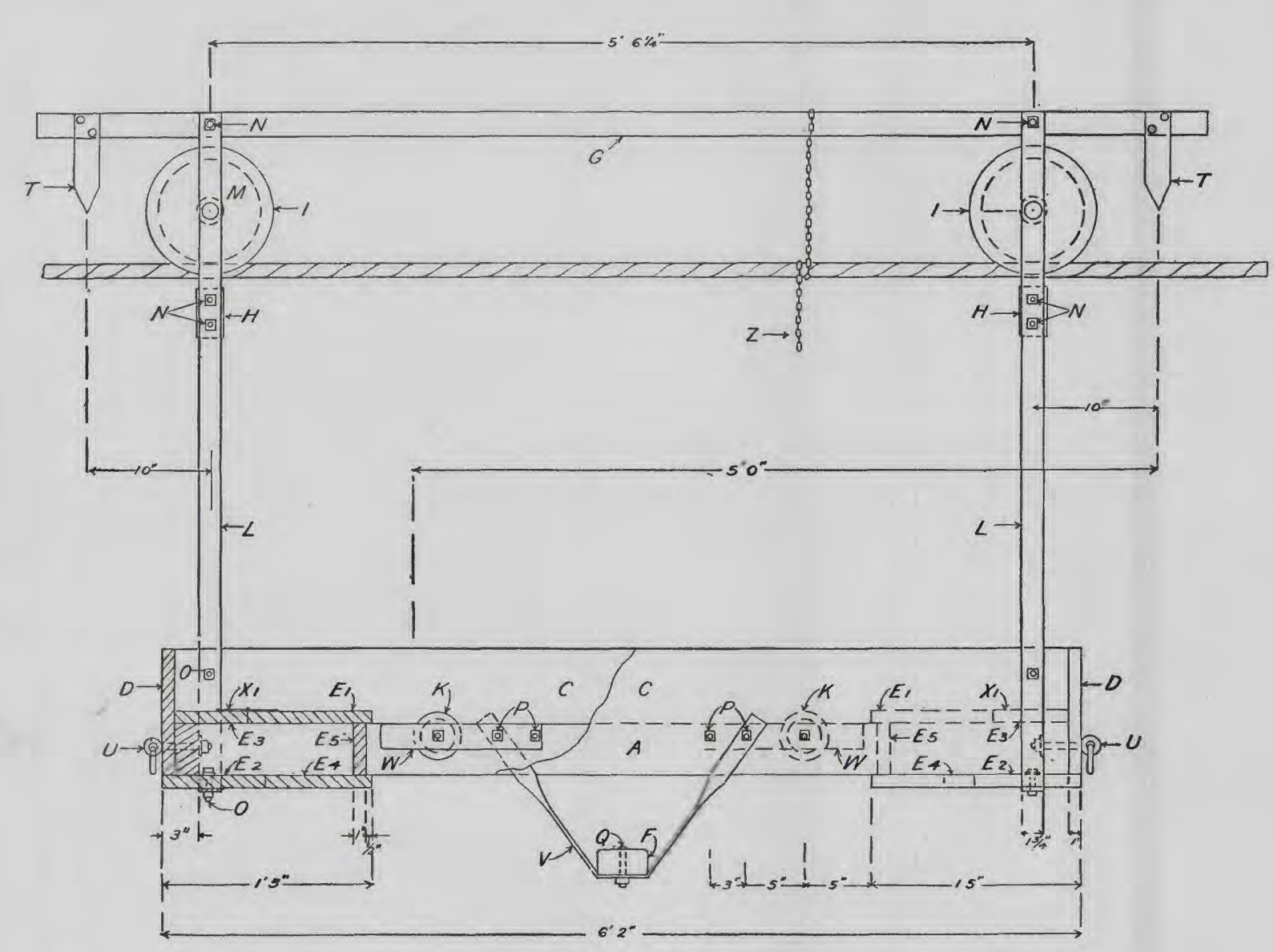

SECTIONAL ELEVATION

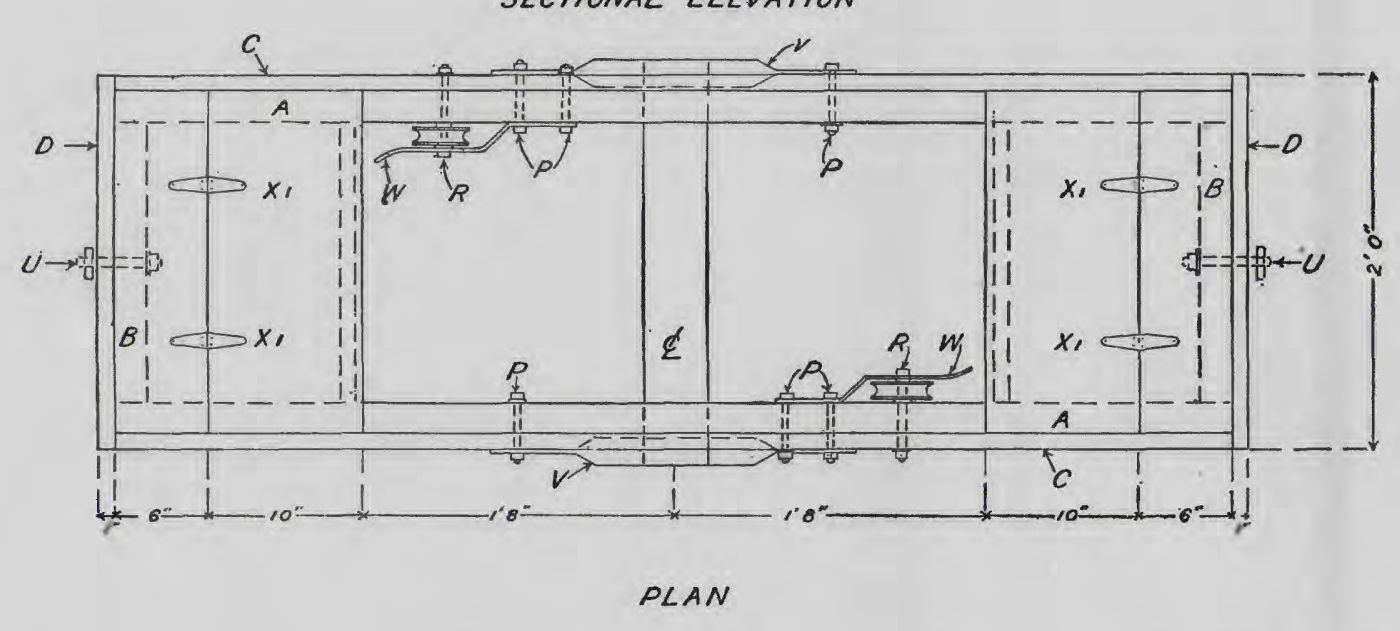

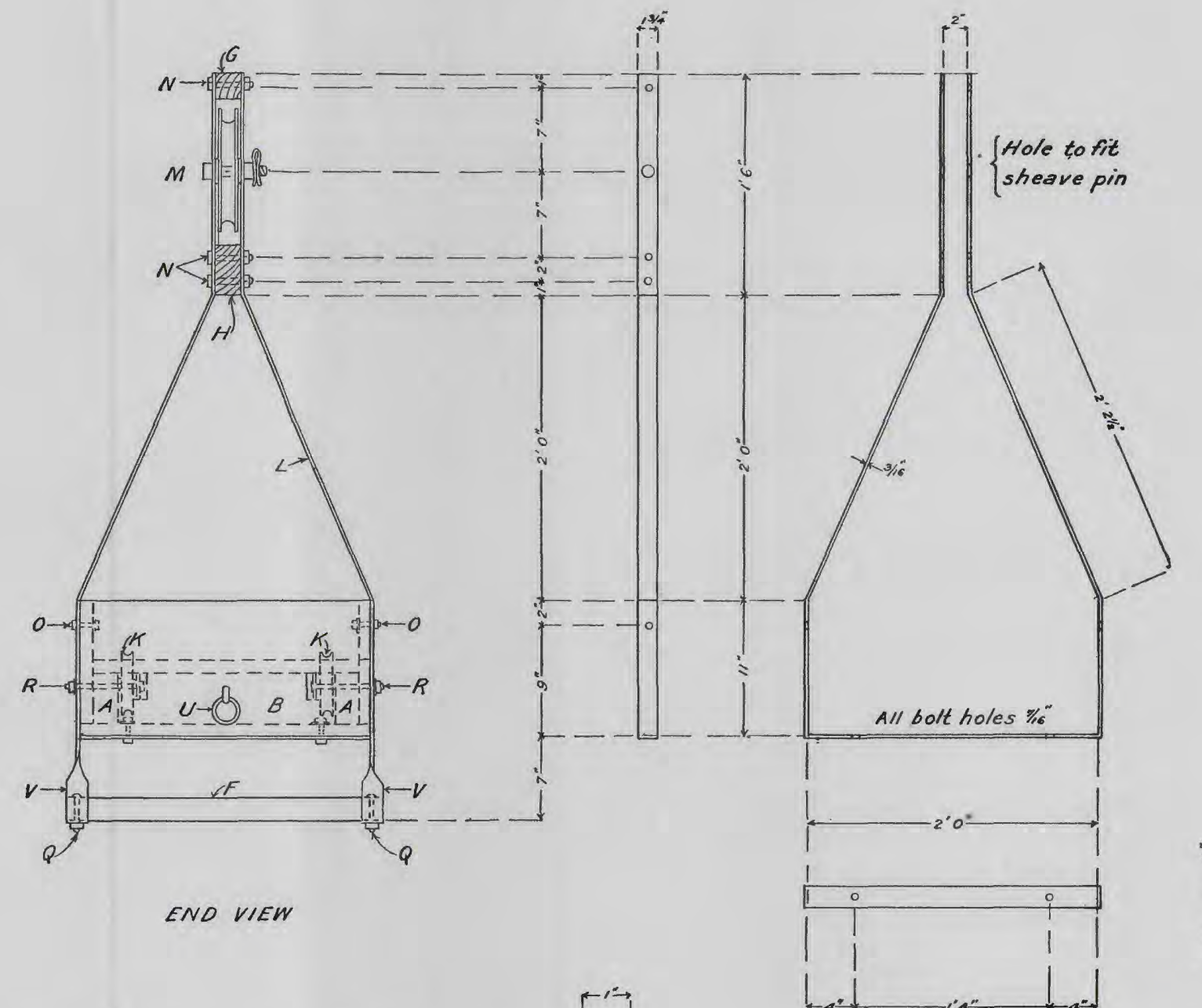

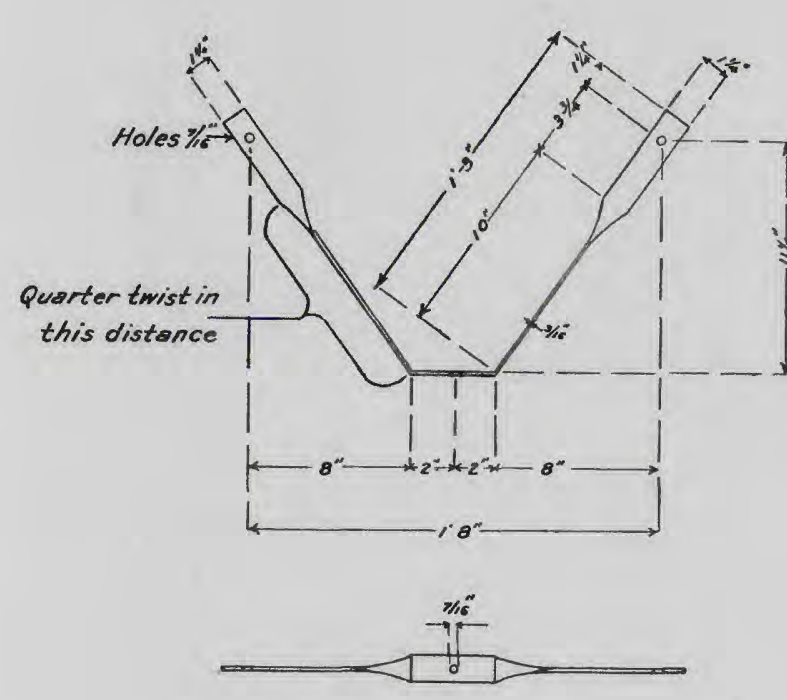

OETAIL OF FOOT-REST HANGER Index $V$

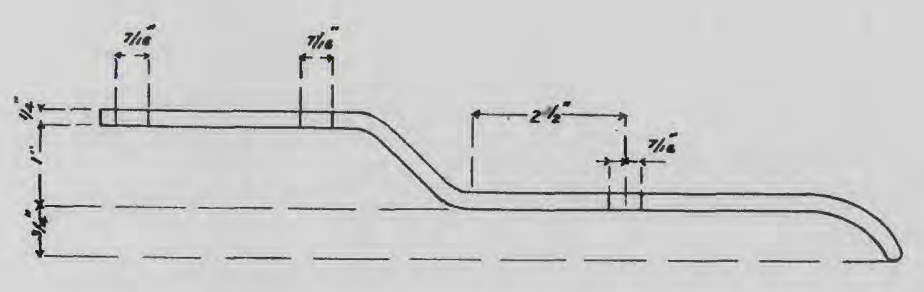

$\square$

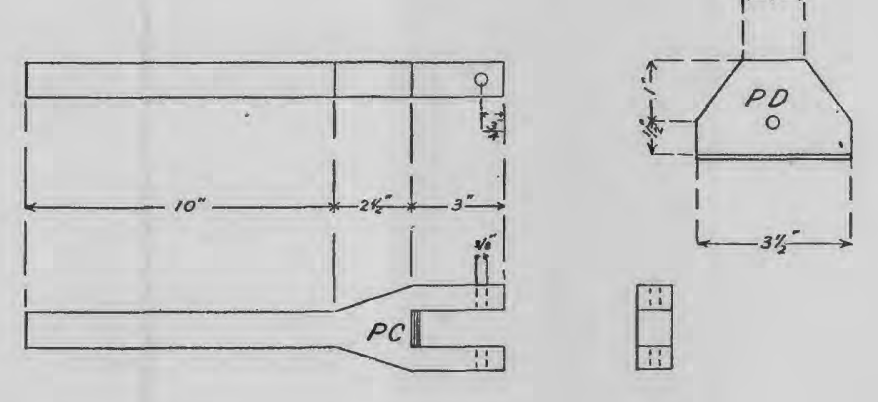

OETAIL OF CAR PULLER
DETAIL OF MAIN HANGER

Index 4

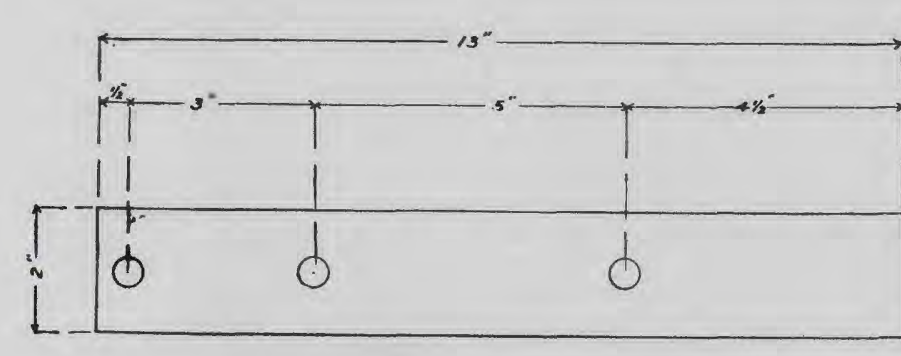

DETAIL OF SIDE-SHEAVE BRACKET 
Item 7. Two cast-iron roller-bearing, spoked sheaves $K, 4$-inch diameter, for $\frac{3}{4}$-inch cable, with machine bolts $R$, of proper size and length for pins, and three washers for each pin, as per detail.

8. Two main hangers $L$, as per detail, galvanized.

9. Six machine bolts $N, \frac{3}{8}$ by 3 inches, for spacers, with nuts.

10. Eight machine bolts $O, \frac{3}{8}$ by $1 \frac{3}{4}$ inches, in main hanger, eight nuts and eight washers.

11. Two foot-rest hangers $V$, as per detail, galvanized.

12. Eight machine bolts $P, \frac{3}{8}$ by 4 inches, in foot-rest hanger.

13. Two carriage bolts $Q$, $\frac{3}{8}$ by $2 \frac{1}{2}$ inches, in foot-rest hanger.

14. Two sheave brackets $W$, as per detail, galvanized, for meter cord sheave.

15. Two swing bolts $U, 7$ inches, galvanized.

16. Four $T$ hinges $X I, 3$ inches, for seat boxes.

17. One gross 2-inch No. 10 F. H. bright wood screws.

18. Two feet gage chain for stop.

19. One standard car puller $P C$.

20. Cleats or cable snub for meter cable.

21. One standard United States Geological Survey padlock.

Noтв. - Sheaves and other parts to be from standard stock as far as practical.

\section{ERECTION.}

The design of the cable equipment having been determined and the material assembled, the erection of the cable structure should proceed about as described below. The anchorages should be completed first and the supports and car constructed next. Then the cable should be attached to the anchorage on the side of the stream least accessible, threaded through the sheaves of the first support, stretched across the stream, threaded through the sheaves of the car and second support, the turnbuckle inserted and attachment to the second anchorage made. The supports should then be raised and and the cable set to the proper sag, a differential block generally being used.

The cable may be stretched across the stream most easily by first stringing a No. 10 wire and securing it to each bank. Then the cable is hung on the wire with carrier hooks, such as are used for carrying lead telephone cables, and drawn across the stream. On streams of moderate velocity, where a boat may be used, the end of the cable may be fastened to the boat and thus kept off the bottom while the boat is pulled across the stream by means of a rope or wire.

On a stream with smooth bottom the cable may be run across the stream in the following manner: Stretch an ordinary telephone wire, of a length at least three times the width of the stream, along the bank at the water's edge, and upstream from the ocable site. The upper end should be fastened or held by an assistant and the lower end fastened to a 2 by 6 inch timber 14 to 16 feet long. The timber should be fastened with a yoke to the wire so that it will float at a decided angle to the current. Another wire, long enough to reach well across the stream, should be fastened to the timber at the cable 
site, the timber set afloat, and the wire paid out as the timber travels across the stream, swinging in an arc around the point where the long wire is fastened or held. With this line a larger line, or rope, may be brought across with which in turn the cable may be pulled across.

The desired sag should be obtained by using a level at a proper distance below the top of the sheave block of one support and setting the lowest point of the cable up to this elevation. With favorable topography a wye level set on the side hill may be used. Otherwise an observer with a hand level is placed on the support with his eye at the proper distance below the sheave.

To detect the possible slipping of the cable clips the clip nearest the end of the cable should be so placed that the cable between it and the next clip back is sufficiently slack to give the effect of a slight loop.

The following list will be found helpful in collecting the tools necessary for the erection of the cable stations and standard shelters. Ordinarily it will be advantageous to fit out a box for the tools, which may then be shipped to the site of the work. The box should contain the following:

Table 30.-Tools for field use.

CARPENTER'S TOOLS.

Squares: 24-inch steel; 6-inch try; 6-inch bevel.

Level: 3-foot spirit.

Rule: 6-foot folding.

Handsaws: 24-inch crosscut, 26-inch rip, teeth of both with wide set.

Wood chisels: Six of different widths.

Hand ax: One 3-pound with nail puller.

Hammer: One good claw hammer.

Screw driver: 8-inch medium; also bits for brace.

Bit brace: One ratchet, 10-inch swing.

Bits: Auger, twist, chain-drill attachment. Include one $\frac{3}{8}$ by 10 inch, one $\frac{5}{8}$ by 14 inch, one $\frac{28}{16}$ by 16 inch.

Files: Six, assorted size and shapes.

Bar: One pinch bar with claw.

MASON's TOOLS.

Trowel: 10-inch brick trowel.

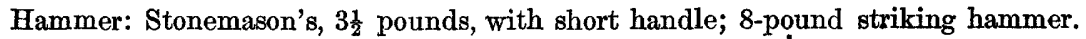

Drills: Four diamond point or star point, $\frac{1}{2}$ inch by 2 feet; three diamond point, $1 \frac{1}{2}$ inches by 3 feet; one diamond póint, $\frac{3}{4}$ inch by 2 feet.

OTHER TOOLS.

Pliers: One lineman's 10-inch; one pair combination.

Cold chisel: One 6-inch.

Wrenches: 6 and 12 inch monkey; 8, 14, and 24 inch Stillson.

Extras: Extra nuts and washers of assorted sizes; extra cable clips.

Picks: Ordinary and grub, if necessary.

Shovels: Short and long handle, as required. 
TACKLE.

Differential: 5 -ton differential block.

Chain: One length $\log$ chain 12 feet; one length cable chain 12 feet.

Rope: 1-inch manila, 50 feet; $\frac{1}{2}$-inch mánila, 100 feet, with steel tackle blocks.

SUNDRIES.

Pails: One water and two bailing pails.

Pump: Diaphragm operated by gasoline engine, where required.

\section{BRIDGES.}

A gaging station established at a place where a stream is crossed by a bridge can generally be installed at a cost lower than that involved in any other installation. Unfortunately the conditions of channel and current that insure accurate records are not always found at existing bridges, so that the saving of expense generally involves the sacrifice of accuracy, which is more surely attained by selecting a site without reference to existing structures. Even if the first cost of a cable station is larger, it will be justified by the material saving that will be effected in maintenance, if the station is to be continued through a considerable period of time, because fewer discharge measurements will be necessary to determine the station rating curve.

If the stream is not too large it may sometimes be advantageous to construct a special wooden or suspension bridge.

The type of wooden footbridge shown in Plate XXXIII may be used on spans up to 80 feet. It is made up of two main stringers $E$, spliced if necessary, and trussed with $\frac{3}{4}$-inch steel rods. The struts $F$ are braced crosswise by the braces $C$ and lengthwise by braces $K$. On the inside of each stringer $E$ is spiked a batten $G, 1$ by 2 inches, upon which rests the 2 by 4 inch floor beams $B$, spaced 4 feet on centers. Tie-rods $T, \frac{5}{8}$ inch in diameter, pierce the stringers $E$ close to the floor beams $B$, which they hold securely in place. Under the ends of the floor planks 4 by 4 inch beams $J$ replace the intermediate beams $B$. Suitable sills $S$ are placed under each end of the bridge.

The structure should be painted with standard gray paint. The bill of material shown in Table 31 is for a bridge 60 feet long; for any other length it should be revised accordingly.

TABLE 31.-Bill of material for standard footbridge.

[Lettered items refer to Plate XXXIII.]

LUMBER.

Item 1. Six pieces $E$, stringers, 6 by 8 inches by 24 feet long ( 576 feet b. m.).

2. Two pieces 6 by 6 inches by 16 feet ( 96 feet $b$. m.), from which cut-

Four pieces $F$, posts, 2 feet 9 inches long.

Two pieces $H$, braces, 2 feet long.

Two pieces $S$, sills, 6 feet 6 inches long. 
Item 3. Four pieces $A$, floor planks, 2 by 12 inches by 16 feet long ( 128 feet $\mathrm{b}$. $\mathrm{m}$.).

4. Five pieces 2 by 4 inches by 16 feet ( 55 feet $b$. m.), from which cut-

Thirteen pieces $B$, floor beams, 2 feet long.

Four pieces $C$, braces, 3 feet 8 inches long.

Four pieces $K$, braces, 7 feet 8 inches long.

5. One piece 4 by 4 inches by 10 feet ( 14 feet $\mathrm{b}$. $\mathrm{m}$.), from which cut three pieces $J$, floor beams under joints, 2 feet long.

6. Ten pieces 1 by 2 inches by 12 feet ( 20 feet b. m.), battens, $G$.

HARDWARE.

Item 7 . Four pieces flat steel, 6 by 6 inches by $\frac{1}{2}$ inch, bearing plates $M$, with $\frac{13}{16}$-inch hole drilled in center.

8. Sixteen machine bolts $D, \frac{3}{4}$ by 8 inches, for splices.

9. Thirty-two ogee cast-iron washers, $\frac{3}{4}$ inch, for bolts $D$.

10. Sixteen steel tie-rods $T, \frac{5}{8}$ inch by 3 feet 3 inches long, with a long thread on each end and two nuts each.

11. Thirty-two ogee cast-iron washers, $\frac{5}{8}$ inch, for rods $T$.

12. Four steel rods, $\frac{3}{4}$ inch, for lower chords, 30 feet 3 inches long, threaded on both ends, with one nut and one ogee cast-iron washer each.

Streams less than 200 feet wide may be spanned by footbridges constructed on supporting cables of $\frac{3}{8}$-inch galvanized plow steel or of cables built up of a sufficient number of parallel strands of No. 10 galvanized-iron wire. When a suspension cable of the latter type is used, it should be built up by passing separate strands across the stream and fastening them in place, the wire being unwound from the coil as used:

Two suspension cables should be carried over the stream at the same elevation and 3 feet apart. They should be supported by trees or A frames if necessary, and the ends should be fastened either to trees or deadmen. Directly over and 3 feet above the main cables there should be two cables to serve as guards and to furnish support and stiffness to the bridge. Each of these cables should be connected vertically with the corresponding lower cable by means of No. 12 wire, or by seizing wire which, being drawn taut, transmits a portion of the load to the upper cable. These verticals should be put in at the end of each 2 by 4 inch by 3-foot 6 -inch floor beam.

The floor beams should be placed 4 feet apart along the lower cable with the 4 -inch dimension vertical. They should be notched 1 inch deep 3 inches back from each end. The notches, together with the vertical connecting wires wound around the crosspieces and the cable at each end, will prevent the crosspieces slipping from the cable.

The floor may be made of two parallel lines of 1 by 8 inch boards, spaced 2 inches apart. Either 12-foot or 16-foot boards should be used, and so laid as to break joints at the ends. The floor boards should be nailed to the 2 by 4 inch floor beams by $2 \frac{1}{2}$-inch"(8d.) nails.

Measuring points should be marked on the bridge floor and the distance from the initial point should be painted beside the marks. 

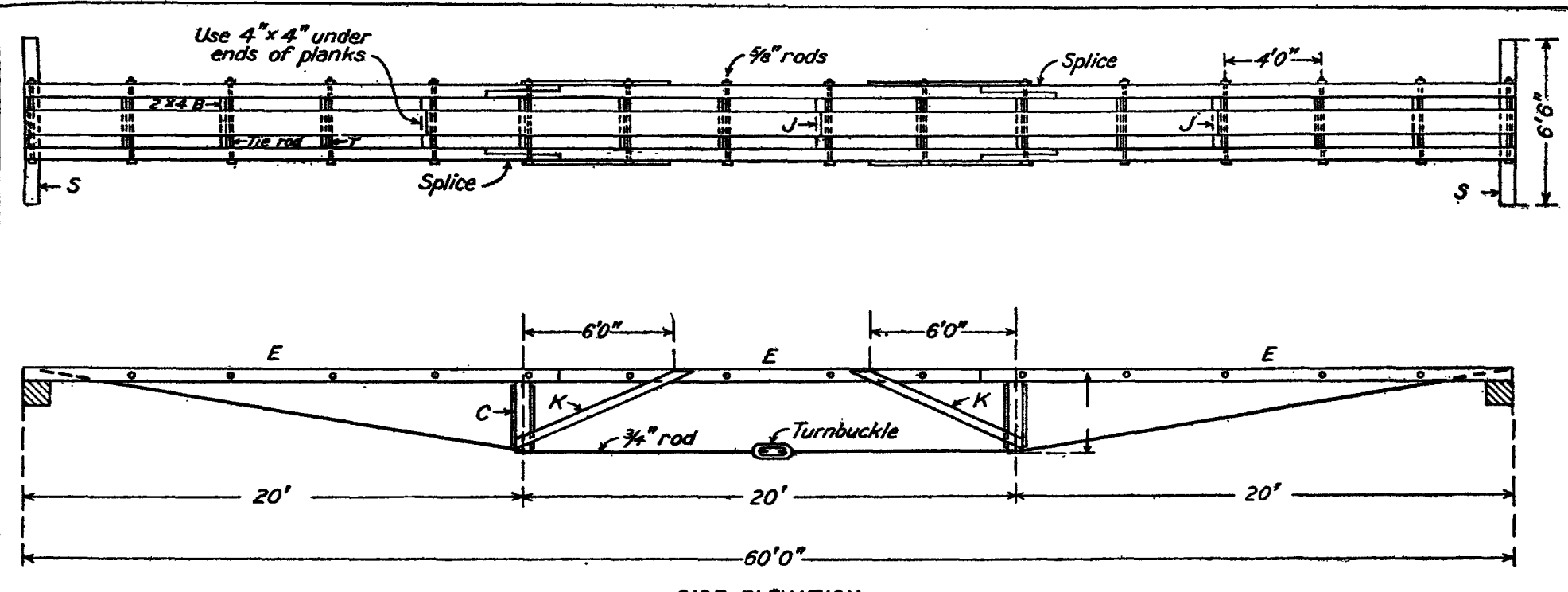

SIDE ELEVATION
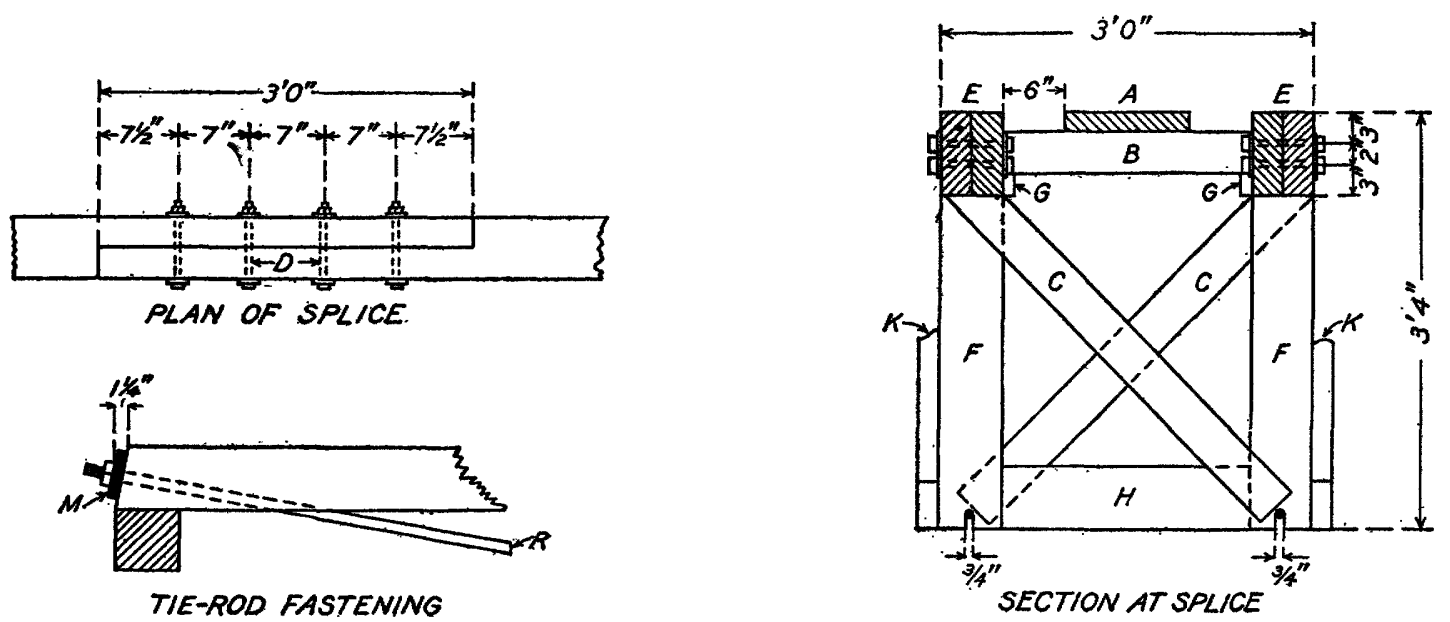

TIE-ROD FASTENING

PLANS FOR STANDARD FOOTBRIDGE.

Bill of material given in Table 31, page 57 . 


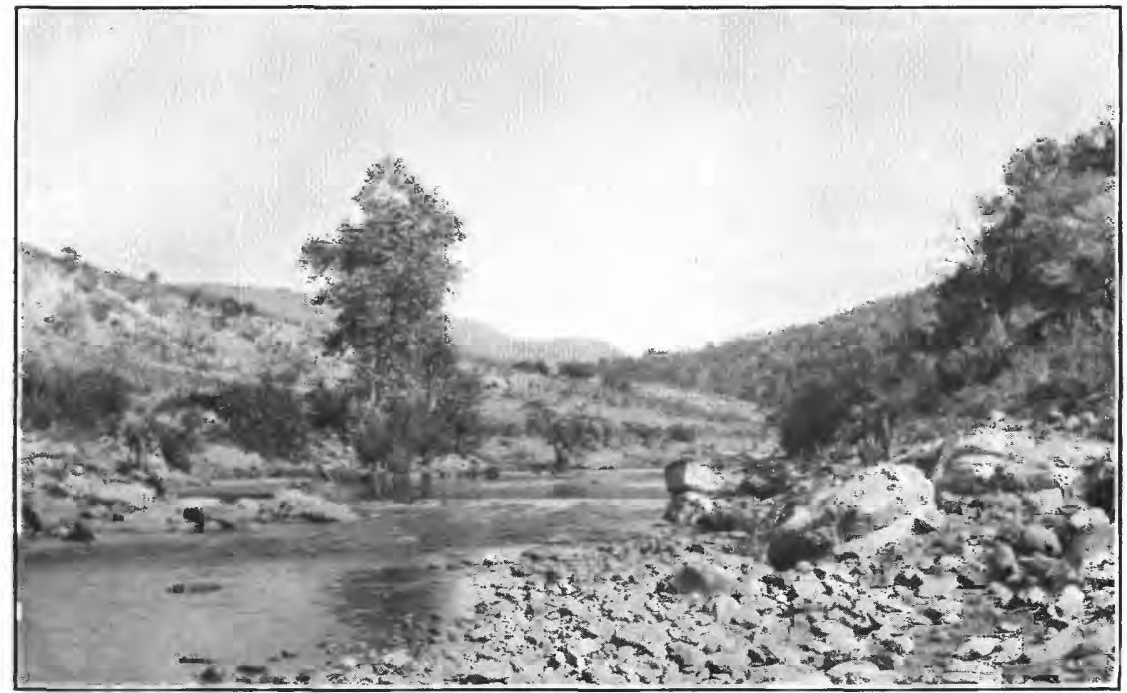

A. EXCELLENT NATURAL CONTROL.

Black River at Fort Apache, Ariz.

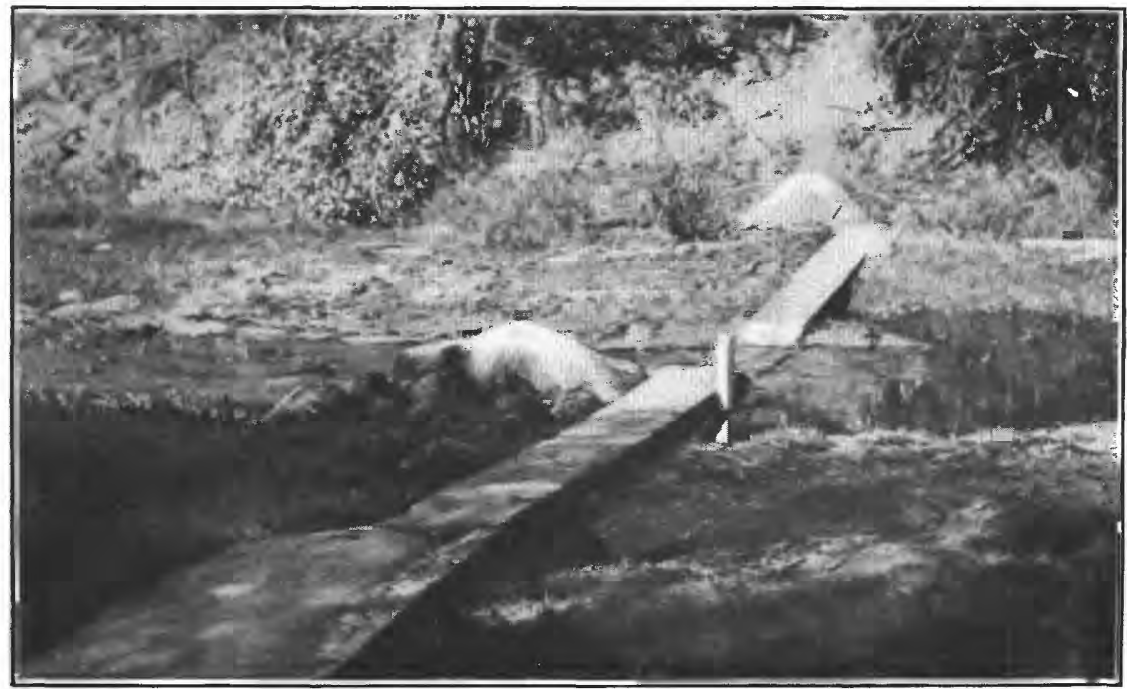

B. ARTIFICIAL CONTROL.

Sweetwater River at Descanso, Cal. 
BOATS.

Boat stations as ordinarily equipped are unsatisfactory because of the difficulty in holding the boat in position while making soundings and in operating the meter, but ferryboats operated from cables can often be used advantageously.

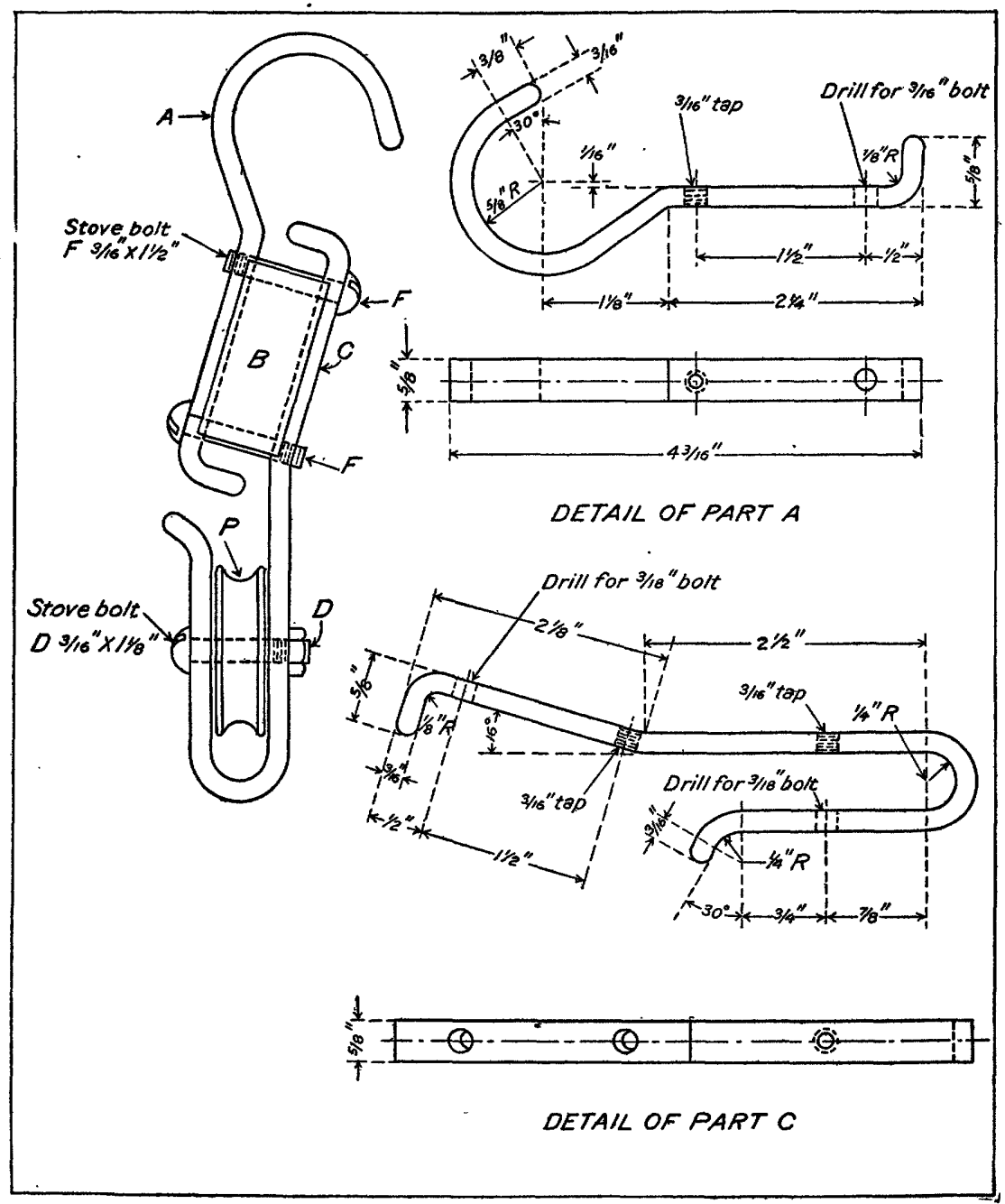

FiGURE 10.-Plans for trolley for use with ferryboats.

In making measurements by this method it is necessary to keep the meter beyond the influence of the boat on the stream. For this purpose the trolley shown in figure 10 is useful. A pole 2 inches in diameter about 10 feet long is squared off at one end and inserted between the pieces $A$ and $C$, which are of medium hard brass. These 
are clamped to the pole by means of the stove bolts $F$. The hooked part $A$ is hung over the ferry cable, and the meter cord is passed over the pulley $P$, the trolley being pushed ahead of the boat as the measurement progresses.

In measuring large streams, such as Niagara, St. Lawrence, and Mississippi rivers, specially constructed and equipped catamarans have been used with great success by the Corps of Engineers of the United States Army, but the equipment is expensive and its use practically restricted to special investigations on important rivers.

\section{TABLE 32.-Bill of material for ferry cable trolley.}

Item 1. One piece each of medium hard brass, $A$ and $C$, dimensions shown on figure 10, drilled and tapped as shown.

One round-head stove bolt $D, \frac{3}{16}$ by $1 \frac{1}{2}$ inches.

Two round-head stove bolts $F, \frac{3}{16}$ by $1 \frac{1}{2}$ inches.

One pulley $P, 1 \frac{1}{1}$ inches diameter.

One pole $B$, at least 10 feet long, to be kept at the ferry station.

\section{STAY LINES.}

A stay line to hold the meter vertical against the drag of the current is a desirable adjunct to a current-meter station. The use of the stay line is illustrated in Plate V, $A$ (p. 15). Stay lines should be fastened to trees or to posts set firmly in the ground and properly guyed. A galvanized eye and eye turnbuckle should be inserted at one end of the line to take up the sag.

The stay line should be placed so far upstream from the cable that the line from meter to stay line makes an angle of not more than $30^{\circ}$ with the horizontal. Half of the distance between the stay line and car may be covered by a No. 10 galvanized wire, one end of which should be attached to a $2 \frac{1}{2}$-inch clothesline pulley rolling on the stay line, the end nearest the car being attached to a 2-inch galvanized awning pulley that will accommodate $\frac{3}{8}$-inch braided sash cord.

The following table will aid in the selection of stay lines:

TABLE 33.-Data for selection of stay lines.

\begin{tabular}{|c|c|c|c|c|c|}
\hline Span. & Stay line. & $\begin{array}{l}\text { Breaking } \\
\text { strength. }\end{array}$ & $\underset{\text { sag. }}{\text { Mini- }}$ & Turnbuckle. & Fastening. \\
\hline $\begin{array}{l}\text { Up to } 200 \text { feet.. } \\
200 \text { to } 500 \text { feet.. }\end{array}$ & $\begin{array}{l}\text { No. } 8 \text { galvanized telegraph wire... } \\
\text { One-fourth inch standard steel }\end{array}$ & $\begin{array}{r}\text { Pounds. } \\
\mathbf{1}, 000 \\
\mathbf{2}, \mathbf{3 0 0}\end{array}$ & $\begin{array}{r}\text { Feet. } \\
2 \\
7\end{array}$ & $\begin{array}{l}\text { One-fourth mch... } \\
\text {.....do............. }\end{array}$ & $\begin{array}{l}\text { Twisted. } \\
\text { Wire clamps. }\end{array}$ \\
\hline 500 to 750 feet. & One-half inch high strength (cru- & 18,000 & 8 & Five-eighths inch. & Do. \\
\hline 750 to 1,000 feet. & $\begin{array}{l}\text { One-half inch extra high strength } \\
\text { (plow steel) wire strand. }\end{array}$ & 27,000 & 15 & $\begin{array}{l}\text { Seven - eighths } \\
\text { inch. }\end{array}$ & Do. \\
\hline
\end{tabular}




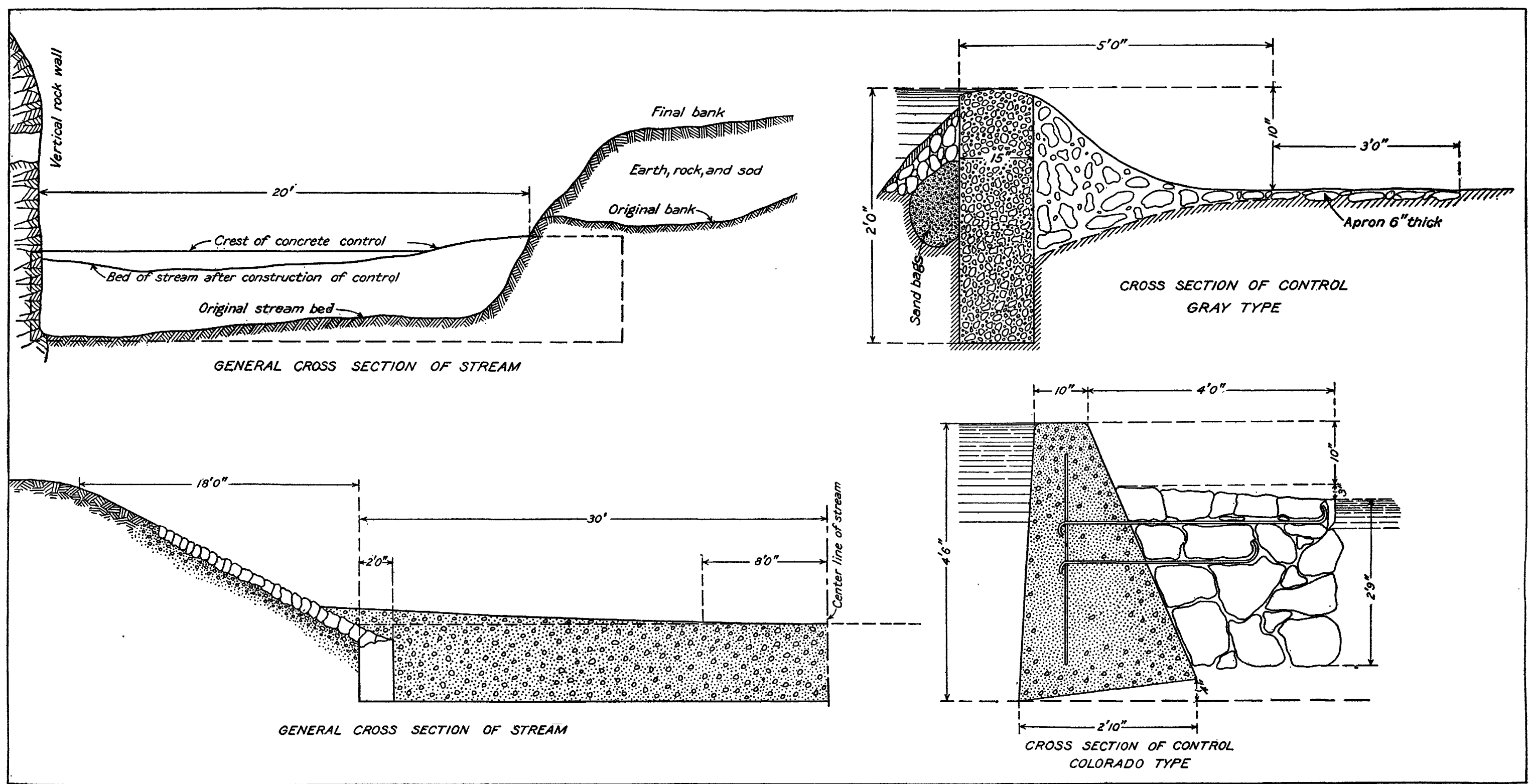

PLANS FOR ARTIFICIAL CONTROL 


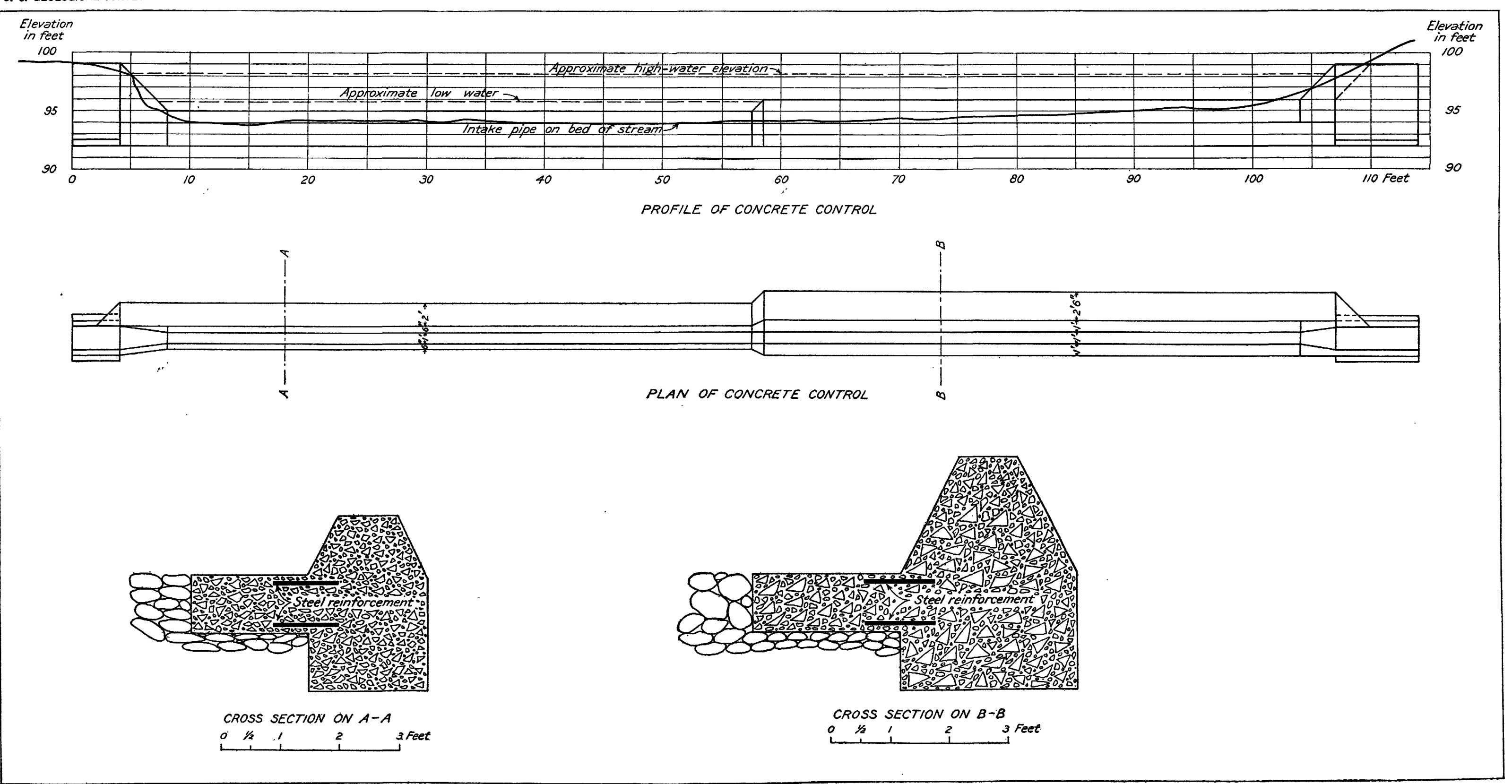

PLANS FOR ARTIFICIAL CONTROL. 


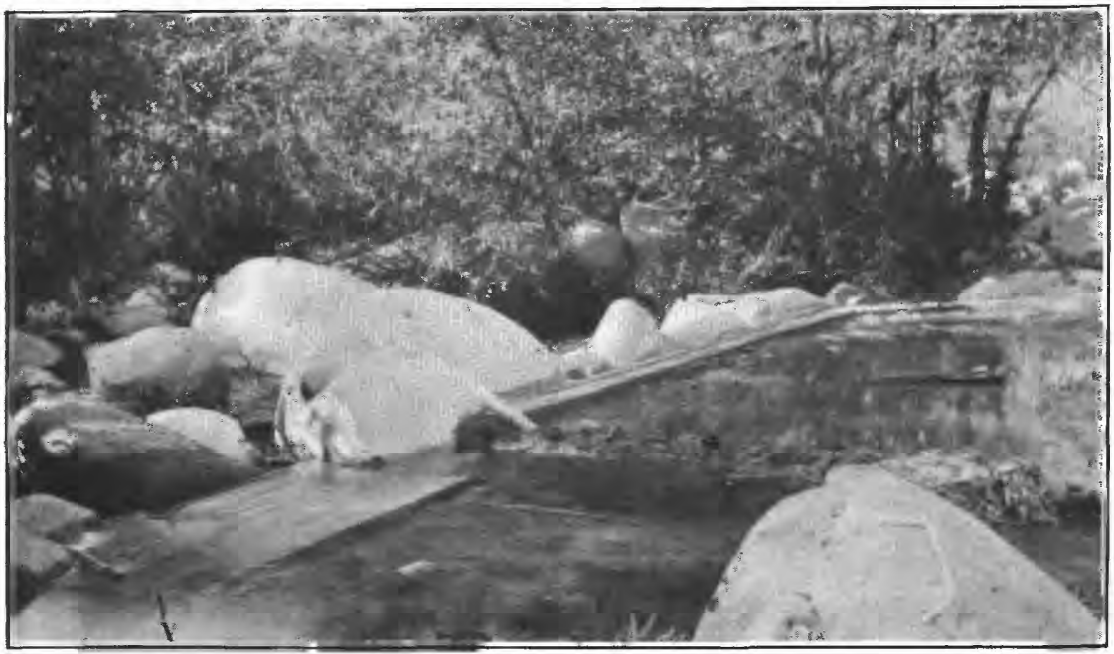

A. SAN LUIS REY RIVER AT PALA, CAL.

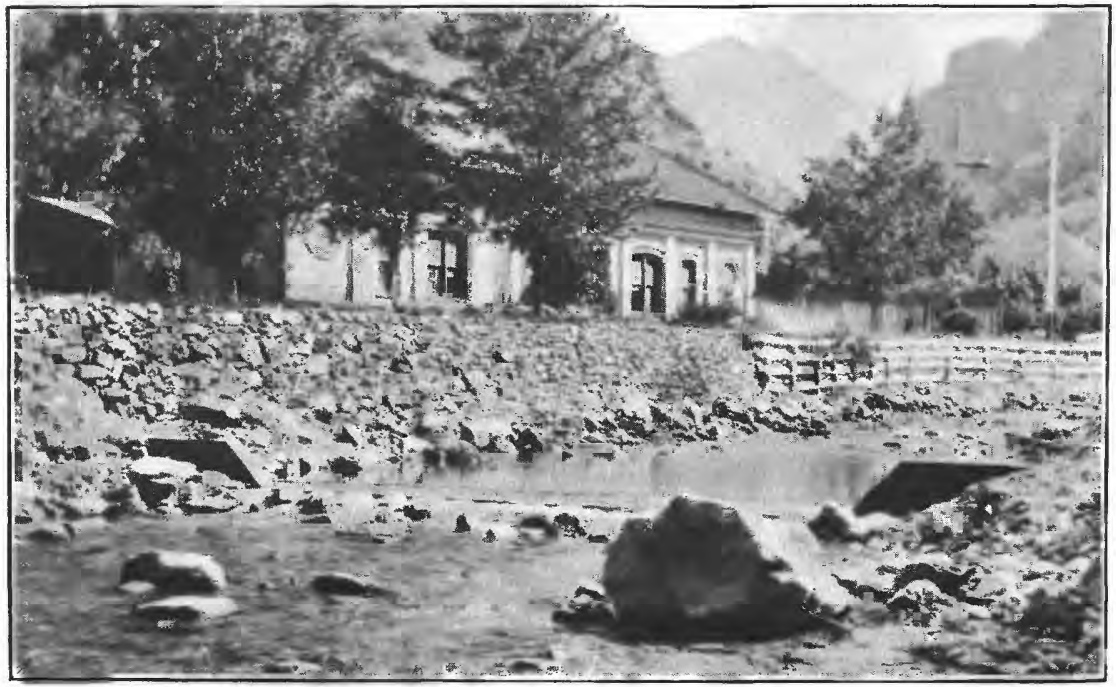

B. LOGAN RIVER AT LOGAN, UTAH.

ARTIFICIAL CONTROLS. 


\section{IINES FOR INDICATING MEASURING POINTS.}

In order that the measuring points at a gaging station may be easily found at the time of making measurements and that the distance between the measuring points may be readily determined, they should be referred to a fixed initial point, and the span should be divided into sections by permanent marks placed at regular intervals on the bridge rail or floor of a bridge station; on the main cable or on a secondary tagged cable of a cable station, or, for measurements made from a boat or by wading, on a tape or tagged line stretched across the stream. If tape or tagged line. can not be left in place, the initial point should be so located and marked that at each discharge measurement the line can be stretched in the same position as for previous measurements.

\section{ARTIFICIAI CONTROL.}

A permanent control, assuring a constant discharge relation, is one of the essential features in the efficient operation of a currentmeter station. At many stations a natural control may be discovered by careful reconnaissance. An especially fine natural control is shown in Plate XXXIV, $A$. At this station a solid rock dike extends entirely across the channel and up on each bank; there is a fall of several tenths of a foot at low water; the rock is smooth; and there is no chance for gravel or silt to deposit behind the control. Such natural controls are, however, exceptional, and on many streams it is impossible to find a control of any kind. This is notably true of most of the streams in southern California and Arizona. The beds of these streams shift greatly during high water, the amount of the change depending rather on the duration of the flood than on its intensity. The changes are greatest in those streams in which the sand and water flow along together all the time, the result being a continually shifting channel. Under such conditions the construction of an artificial control may make it possible to obtain an accurate station discharge curve with a reasonable number of stream measurements.

Artificial controls should be made to conform as nearly as possible to the contour of the stream bed, so that the natural adjustment of the stream to its channel will be disturbed as little as possible. The site should be selected only after careful reconnaissance. Bedrock, either exposed or buried at shallow depth, or a nest of bowlders afford's the best anchorage or foundation for the control and the apron which is to receive the overfall. There must be a free fall along the channel below the control in order to prevent the formation of secondary sand controls that would destroy the effectiveness of the structure. The velocity over the control should be sufficient 
to prevent the pool above it from silting up but not so great that the sand will abrade the material of which the control is built. A lip of thin flat steel placed in the top of the control near the downstream face, so as to give a free overflow, will prevent abrasion. In order that the station may be sensitive, the low-water flow should be concentrated within narrow limits by giving the control a section across the stream concave upward.

Plans for artificial controls are given in Plate XXXV, and a successful special control that was built on the outlet of Owasco Lake, in central Now York, is shown in Plate XXXVI.

A typical artificial control, shown in Plate XXXIV, $B$, consists of three sections of concrete beams resting on top of buried bowlders the downstream side being supported by bowlders that project above the stream bed. A piece of flat steel, $\frac{3}{16}$ by 5 inches, was placed in the top of the concrete, on edge, the top of the steel being an inch higher than the concrete. The apron receiving the overflow is made of concrete. Another artificial control is shown in Plate XXXVII, A. To provide a footing for this control a trench was dug, and into this trench two-men bowlders were rolled; the interstices were filled with smaller stones; the whole was cemented together with concrete. The footing supports a 10-inch concrete wall and the projecting apron. The contour of the crest conforms closely to the cross section of the stream. The crest of the low-water section is protected by a lip made from an old wagon tire. The total length of the structure is 38 feet. The ends are anchored to bowlders on the banks.

A very simple artificial control used in connection with stream measurements at a power station is shown in Plate XXXVII, $B$.

Concrete is an excellent material with which to build these controls, the aggregate usually being found near by. If wet the sand and gravel should be shoveled into a pile to dry for a few days before being used. The cement sacks, when filled with sand, are useful in turning the channel. Flat steel $\frac{3}{16}$ inch by 5 inches may be obtained from stock, and makes a good lip. It is easily straightened and can be cut cold with a hack saw. Dynamite is the most effective agent for removing obstructions from the channel above the control. 


\section{INDEX.}

B.

Backstay, size and position of.

Bench-mark tablet, water resources, plate showing ......................

Bench marks, station, placing of.............

Boats, use of.

Bridge piers, gage on, plate showing.........

Bridges, gaging stations at.................. See also Footbridge.

\section{c.}

Cable, anchorages for anchorages for, plans of.................. erection of......................... 55-56

sag of, diagram showing................ tables showing.

supports for, construction of........... 42-44

material for...................... 44-47

plans of........................... 42

plate showing..................... 44

Cable installation, material for............. 53

Car, cable, construction of................ 53-54

cable, material of ................... 54-55 plans for......................... 54

plate showing ..................... 44

Clips, cable, use of ..................... 53

Control, artificial, construction of.......... 61-62 artificial, plans for.................... $\quad 60$ plates showing................... 58-60 excellent natural, plate showing......... 58

Cushing bridge piers, gage on, plate showing. .

D.

Deadmen, construction of. plans of.

Discharge measurements, structures used for . 41-61

\section{F.}

Ferry cable trolley, construction and material of............................ 59-60

Footbridge, construction and material of.... 57-58 plans for

Forms for concrete work, construction of..... $38-40$ material for.......................... 40-41

Freezing, protection from................. 24

Friez automatic recording gage, plate showing

G.

Gage, chain, description of............... 9-10 chain, material for .................. 10-11 plan of box and weight for.......... 10 float, description of.................... 9 hook, description of . ................. 8 material for plate showing. crete piers.................... 11-12 inclined-staff, attachment of, to timber posts...

material for ....................... 12, 13

plate showing ..................... 8

recording, concrete wells for, construction of . ............................ 20-23

installation for..................... 13-14

intake of, anchorage for............ 19-20

plate showing...................... 14

shelters for . . . . . . . . . . . . . . . . . $25-38$

timber-lined well for, construction of . 15-19 material for................ 15, 16-17 plans of, plate showing .......... $\quad 16$

slope, plans for .................... 12

vertical-staff, description of............. 8

plate showing.................... 8

Gage table, construction and material for.... 38

Gages, nonrecording, descriptions of........ 8-13

Gaging station, typical, plate showing....... 15

Gurley automatic recording gage, plate showing ......................... 14

\section{H.}

Heating of gage well, devices for 24,25

\section{I.}

Intake, anchorage for................... 19-20 anchorage for, sections and details of.... 20 pipe for.......................... 15

M.

Measuring points, modes of indicating.......

o.

Outline of equipment......................

R.

Rock ledges, use of, for anchorages.

S.

Shelter, box, construction of............. 29

box, material for...................... $\quad 29$

plans of.......................... 28

plate showing.................. 15, 30

California, construction of............. 27 material for...................... 28

plans of......................... 28

plate showing.................... 18

concrete, combined with gage well, construction and material of..... 20, 22-23 plain construction of .............. 31-32 material for....................... 33-35 plans of ........................ 34 
Shelter, Hawaijan plate showing Page. metal, plate showing................ $\quad 36$

miscellaneous designs for. plates showing.........31,36,37,38, 39, 40 portable, construction of ............ 30 material for ..................... 31

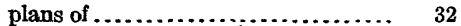

plate showing................... $\quad 31$

reinforced concrete, construction of...... 35

forms for . . . . . . . . . . . . . . . .

material for $\ldots \ldots \ldots \ldots \ldots \ldots \ldots \ldots \ldots . \quad 36$

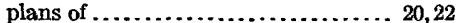

sectional wooden, construction of. . . . . . 25-26

material for ....................... 26-27

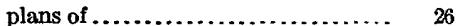

plate showing ................... 30

ventilation of $\ldots \ldots \ldots \ldots \ldots . . . \ldots .37-38$

Shelter for automatic gage, plates showing. $38,39,40$

Stay lines, selection and placing of ......... 60

Stevens automatic recording gage, plate show-

ing.
T.

Page.

Tools, list of . . . . . . . . . . . . . . . . . $56-57$

Trees, use of, for anchorages............. 49

Trolley for ferryboat cable, construction and material of . . . . . . . . . . . . . . . $59-60$

Turnbuckles, size and position of ......... 52-53

\section{v.}

Ventilation of shelters................... 37-38

$\mathbf{W .}$

Well in a rock bank, plate showing........ 18

Well with no intake, plate showing ........ 15

Wells, concrete, construction of ..........20-23 concrete, material for....... 20-21, 21-22, 22-23 plans of . ...................... 20,22

miscellaneous designs for ............. 23-24

timber-lined, construction of......... 15-19

dimensions of................... 14

material for .................. 16-17

plans, of $\ldots \ldots \ldots \ldots \ldots \ldots \ldots \ldots \ldots \ldots . \ldots \ldots$ 